\title{
The German Eipo Research Project
}

\section{Anton Ploeg}

\section{OpenEdition}

\section{Journals}

Édition électronique

URL : http://journals.openedition.org/jso/263

DOI : $10.4000 /$ jso. 263

ISSN : 1760-7256

Éditeur

Société des océanistes

Édition imprimée

Date de publication : 1 juin 2004

Pagination : 35-79

ISSN : 0300-953x

\section{Référence électronique}

Anton Ploeg, «The German Eipo Research Project », Journal de la Société des Océanistes [En ligne],

118| Année 2004-1, mis en ligne le 01 juin 2007, consulté le 01 mai 2019. URL : http:// journals.openedition.org/jso/263; DOI : 10.4000/jso.263 


\section{The German Eipo Research Project}

par

Anton PLOEG*

\begin{abstract}
This paper reviews the results of the research carried out that a group of German scholars and scientists has carried out with the Eipo, in the eastern highlands of West Papua, Indonesia. Their work started in the mid1970's and has not been completely finalised so far. The research aimed at a comprehensive documentation of the way of life of the Eipo. This aim required the interdisciplinarity that characterised the project, although anthropology was the central discipline. It also required the production of a large body of maps, photographs and films. I add to the review a list of the published results.
\end{abstract}

KeYwords: Culture, Ecology, Human ethology, Oral history, Gender relations.

\section{Acknowledgements}

My writing this review essay would not have been possible without the help and support of a sizeable number of persons and institutions. I first would like to thank members of the Eipo research team for their willingness to provide me with information. I mention especially Prof. Dr. V. Heeschen, Prof. Dr. G. Koch and Prof. Dr. W. Schiefenhövel. Prof. Heeschen introduced me to the Forschungsstelle für Humanethologie, the Research Institute for Human Ethology, at Andechs, Bavaria. Dr. R. Hussmann and staff

\section{RÉSUMÉ}

Cet article présente les résultats de recherche menées par un groupe d'étudiants et de scientifiques allemands chez les Eipo, dans les hautes terres de l'est de la Papouasie de l'Ouest en Indonésie. Leur travail, qui a commencé dans le milieu des années 1970, n'a été complètement terminé. Cette recherche a voulu présenter une bonne documentation sur la façon de vivre des Eipo. Ce but a nécessité une interdisciplinarité et c'est une des caractéristiques de ce projet, bien que l'anthropologie en soit la discipline centrale. Il a aussi réclamé la production d'un grand nombre de cartes, prohtographies et films. Je présente ici une liste des résultats publiés.

MoTS-CLÉS : Culture, écologie, ethologie humaine, histoire orale, relations de genre.

members of the Institut für den Wissenschaftlichen Film, Göttingen, Niedersachsen, gave me the opportunity to let me view a number of the films produced by the Eipo team. A Visiting Fellowship in the Anthropology Department of the Research School of Pacific and Asian Studies, The Australian National University, Canberra, enabled me to start drafting the text of this review. I thank the School for its hospitality and the members of the anthropology department for constructive comments. R. van der Haar, Centre for Pacific and Asian Studies, Nijmegen University helped me to locate hard to

* Centre for Pacific and Asian Studies, Nijmegen University, the Netherlands, ploeg228@zonnet.nl. 


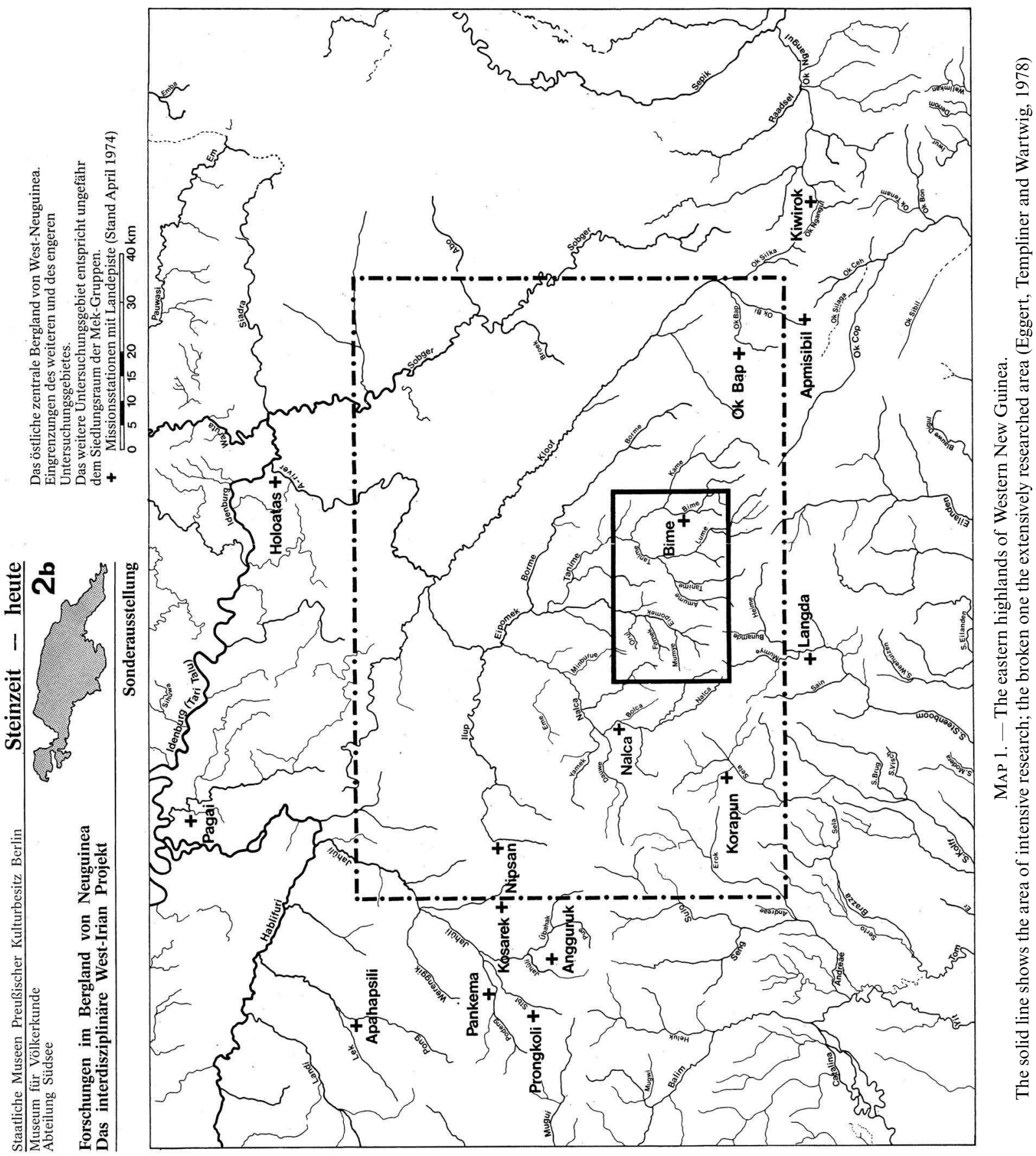


trace publications. I am grateful to Prof. John Barnes, Prof. J Pouwer and two anonymous reviewers of this journal for their comments on an earlier draft of this paper, and to Annegret Schemberg and Magda Bolt, my wife, for their help in interpreting and translating words and sentences in the German originals. The remaining English translations are my own. As always, Dr. G.N. Appell, Phillips, Maine, was most supportive.

\section{The Project}

In mid-1974 a team of German scholars started carrying out field research with the Eipo, in the eastern parts of the Central Highlands of western New Guinea (see map 1). It was a large, interdisciplinary team of which 24 scholars were members. There was one woman among them: Grete Schiefenhövel. A list of the team members (Koch and Helfrich, 1978c) mentions four other women as co-workers, some apparently the wives of team members, as was Schiefenhövel. Koch (1990: 3) writes that the team unsuccessfully attempted to enlist Indonesian counterparts.

The field work periods of the members varied in length. None stayed the entire period. Their work resulted in a large body of textual and audio-visual publications, mostly in German. Central is the series of papers and monographs, entitled Mensch, Kultur und Umwelt im zentralen Bergland von West-Neuguinea [People, Culture and Environment in the Central Highlands of western New Guinea], here abbreviated as MKU. So far 20 volumes have been published and more have been announced. In addition the participants in the project have published a great many papers in journals and edited books. A good introduction to the results is the guide to an exhibition about the project held in the Anthropology Museum in Berlin, in 1978. The guide consists of a number of separate sheets each one dealing with an aspect of the project. In 1990, the team organised a conference in Seewiesen, Bavaria, to signal the formal end of the project (Schiefenhövel, 1991). It did not result in a publication. This is doubly unfortunate: firstly because the papers presented were in English, unlike most of the other publications resulting from the project, and, secondly, because other New Guinea specialists attended and presented papers. Apart from the written results, the team produced a large number of sound, film and photographic material (Simon, 1978; Heeschen, 1986a; Schiefenhövel, 1988b). The films are held in, and available from, the Institut für den Wissenschaftlichen Film ${ }^{1}$. Moreover, the team brought a comprehensive collection of Eipo material artefacts together, now held in museums in Abepura, West Papua, and in Berlin. Most of them are shown in pictures and/or drawings in Koch's 1984 MKU monograph (Koch, pers. comm. 2003). In the Berlin museum a project archive was set up, that, however, at the time of writing, was difficult to access (Helfrich, pers. comm. 2003). The ethology institute in Andechs has a sound archive (Heeschen, 1986). Further publications of the results are still in preparation.

Below, in table 1, I list the main participants of the first phase of the project and their disciplinary specialisations (Koch and Helfrich, 1978c). In a third column, I mention the MKU monographs and/or papers they have written, and/or the ones to which they have contributed. The last column mentions the number of the exhibition guide sheet on which they introduce their work. I refer to the monograph series by the acronym MKU, and refer to the guide sheets by number only.

Koch and Helfrich, two anthropologists, initia ted the project. Their idea was to study the culture of a group of people that had not been reached by «western influences ». « Culture $»$ they defined in two ways, first by an enumeration of elements, as did Tylor in one of the earliest definitions of the concept, and, secondly, by referring to human ontology. According to their first definition the culture of an ethnic group is:

« the totality of all ideas, knowledge, conceptions, ways of behaving, skills, material and immaterial artefacts that characterise these people and that they transmit to their progeny either directly, in their specific forms or by the conditions of their learning systems » (Koch and Helfrich, 1978a).

Their second, more general, definition was: «culture is the way in which people give

1. The films are in various stages of documentation. Most of the copies held in the Göttingen institute are silent film versions, with dubbed in comments. As far as some are concerned, comments have still to be provided. The same holds for accompanying papers published in separate issues of the institute's Publikationen zu Wissenschaftlichen Filmen. The institute is considering using the material for making a CD-rom about the Eipo. At the Forschungsstelle für Humanethologie, at Andechs, video versions of many of the films are held. They can be viewed the films are held. They can be viewed there, but are not available for loan These versions have available for loan. These versions have the original sound tracks. The Institute at Andechs holds also a great deal of uncut film material. 


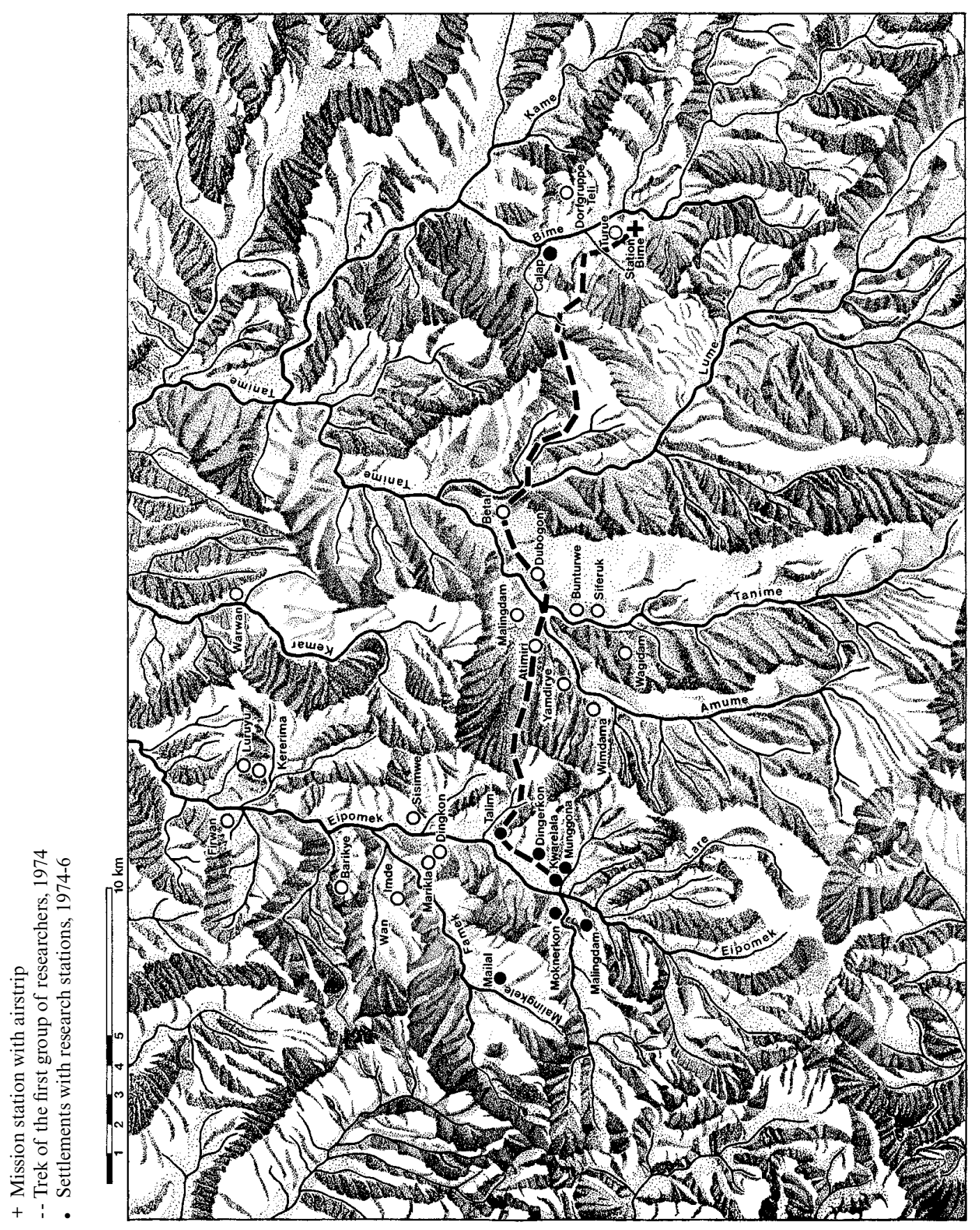




\begin{tabular}{|c|c|c|c|}
\hline D. Helmcke & Geology & MKU 4, 13 and 14 & 4 \\
\hline G. Hoffman & Climatology & MKU 9 & 5 \\
\hline $\begin{array}{l}\text { P. Hiepko } \\
\text { W. Schultze-Motel }\end{array}$ & Botany & MKU 5, 7 & 6 \\
\hline $\begin{array}{l}\text { P. Blum } \\
\text { W. Schultz } \\
\text { G. Heidemann } \\
\text { G. Konrad }\end{array}$ & Zoology & MKU 2 & 7 and 8 \\
\hline E. Büchi & Physical Anthropology & MKU 8 & 9 \\
\hline G. Schiefenhövel & Dentistry & & 10 \\
\hline G. Konrad & Medicine & MKU 3 & 11 \\
\hline H. Jüptner & Tropical Medicine & MKU 12 & 12 \\
\hline W. Schiefenhövel & Ethnomedicine & MKU 6, 16 and 19 & 13 \\
\hline I. Eibl-Eibesfeldt & Human Ethology & MKU 19 & 14 \\
\hline V. Heeschen & Linguistics & MKU 6, 20, 22, 23 & 15 \\
\hline W. Röll and G. Zimmermann & Human Geography & MKU 1 & \\
\hline $\begin{array}{l}\text { G. Koch } \\
\text { K. Helfrich } \\
\text { Th. Michel } \\
\text { W. Nelke }\end{array}$ & Anthropology & $\begin{array}{l}\text { MKU } 15 \\
\text { MK11 }\end{array}$ & 16 to 23,27 \\
\hline F. Simon & Film Documentation & & 24 \\
\hline $\begin{array}{l}\text { A. Simon } \\
\text { E. Royl }\end{array}$ & Musicology & & 25 \\
\hline
\end{tabular}

TABLE 1. - First Phase Members Of The Eipo Research Team

form to their lives » (unpublished Grant Proposal to the Deutsche Forschungsgesellschaft, 1983: 2) $)^{2}$.

Koch and Helfrich argued further that the capacity to do so is a topic to be studied by also a human biologist. They held, thirdly, that a culture is shaped by the natural environment in which the people concerned live. These considerations prompted them to choose " Man, Culture and Environment » as the title of the project's major publication series.

The aim of the project was « to come to a documentation, as circumstantial and systematic as possible, of the population of one of the high valleys in the Central Highlands of New Guinea, of their culture and of their habitat » (Koch and Helfrich, 1978a) ${ }^{3}$. I infer from this wording that the initiators of the project did not apply a criterion of relevance to any specific culture element. Instead, it seems, they left it to the individual researchers to bring to the fore the elements on which their respective disciplines focused. The broad aim they envisaged necessitated an interdisciplinary approach (Koch and
Helfrich, 1978a), with anthropology as the central discipline. As Table 1 makes it clear, anthropologists outnumbered the representatives of any of the other disciplines. Natural scientists received training in anthropology before departing for the field (Koch, pers. comm. 2003). The anthropological seal of the team's research aim shows in the topics they have investigated, such as ethnoscience, resource use and ecology. The interdisciplinarity of the results was to be enhanced by instituting an editing committee of the MKU series consisting of six scholars: Helfrich, Jacobshagen, Koch, Krieger, Schiefenhövel and Schulz - three anthropologists, one geologist, one medical scientist and one zoologist. The committee functioned until about 1988, commenting extensively on each draft submitted (Koch, pers. comm. 2003). Given its composition, it strengthened the centrality of anthropology in the results of the project. In my view, its centrality was further promoted because in the course of the project especially Schiefenhövel and Heeschen deepened their interest in anthropology.

2. The German original of the first definition is: « die Gesamtheit aller Ideen, Kenntnisse, Vorstellungen, Verhaltensweisen, Fertigkeiten, materiellen und nichtmateriellen Gestaltungen, die jene Menschen charakterisieren und die selbst oder in iheren Voraussetzungen über Lernsysteme an ihre Nachkommen weitergegeben werden. » The English version of the second definition is a translation of « Kultur ist die Art und Weise menschlicher Daseinsgestaltung ».

3. In German: «eine möglichst ausführliche und systematische Dokumentation über die Bevölkerung in einem der Höchtäler des zentralen Berglandes von Neuguinea, über ihre Kultur und ihren natürlichem Lebensraum erstellen ». 
At the time the team started its work, the Eipo were indeed largely uncontacted by the Indonesian authorities, missionaries and European explorers. Exceptions were, first, the expedition of Gaisseau that entered the valley in 1958 (Saulnier, 1963). Ten years later Gaisseau, accompanied by Indonesian army personnel, dropped into the valley by parachute (Laporan, 1969; Schiefenhövel, 1997a), describes the reactions of the Eipo to these first two encounters). The eastern highlands of western New Guinea form an area characterised by a central divide running east-west, with transverse valleys running both north and south. They are most often narrow and deeply incised, with only occasional wider stretches. Minor and major landslides occur regularly and the situation is in many parts aggravated by high rainfall. At the time of the expedition, annual rainfall in the Eipo valley was around $6000 \mathrm{~mm}$ (Hoffmann and Hoffmann, 1988). To reach the Eipo, the first researchers had to trek for days from the nearest airstrip at Bime (see map 2). In the Eipo valley, they started work by having their own airstrip constructed (Koch and Helfrich, 1978b). Much more than in the highlands of Papua New Guinea, in western New Guinea scholarly work has been carried out by expeditions, often multidisciplinary. Bakels and de Jonge (2001: 18) describe the 1961 Harvard Peabody expedition led by Gardner as the last one. However, that description should go to the Eipo expedition and Bakels and de Jonge's comment shows that its results have not become widely known, in my view unjustifiably so.

The team was unable to complete its research. In mid-1976 a heavy earthquake destroyed part of the Eipo habitat, killing a number of people. A second earthquake in October that same year added to the damage and subsequent epidemics caused further casualties. After the earthquakes, the researchers spent much of their time organising relief measures ${ }^{4}$. Moreover, the team's work was troubled by the political turmoil in the highlands with the Indonesian army fighting New Guineans, both villagers and freedom fighters of the OPM, the Organisasi Papua Merdeka, with New Guineans fighting among themselves, and with refugees moving to the border with Papua New Guinea (Hayward, 1997: 208f; Dorney, 2000: 216f). Under these conditions, the Indonesian authorities did not extend the team's research permits (Koch and Helfrich, 1978b).
But in 1979, the project was resumed (Heeschen, pers. comm.). From that time several researchers, notably Eibl-Eibesfeldt, Heeschen and Schiefenhövel revisited, or kept revisiting, the Eipo, to follow up their research. The three worked at the Andechs institute for human ethology, so research interest shifted from the scholarly, anthropological focus formulated by Koch and Helfrich to a more scientifically oriented, biological approach. In order to include these different approaches to the study of human affairs under a single heading, I use the term " anthropology » here in a broad sense. The project did not come to include the full range of disciplines that the initiators had had in mind, while several participants published only a small part of their data. The earth sciences are underrepresented in the results. While archaeology is still absent, there are plans to rectify this situation (Schiefenhövel, pers. comm. 2002). As regards stone technology, the Pétrequins, from the late 1980's to the early 1990's, researched quarries and other sources of stone that could be fashioned into implements. In the eastern highlands all appeared to be located south of the main divide (Pétrequin, 1990; 1993: 217f).

Eibl-Eibesfeldt went back to the field in 1981, Wulf Schiefenhövel in 1980 (Eibl-Eibesfeldt, Schiefenhövel and Heeschen, 1989: 16). The plant geneticist Plarre carried out field research in 1981 (1995). Michel later worked with a group of Nalumin, living in Papua New Guinea close to the border with western New Guinea (Michel, 1986, 1988, 1994). The Nalumin are the people whom Hylkema (1974) first named Nalum, but later in unpublished manuscripts Ngalum, and Craig and Hyndman (1990: 217, fig. 6) Sibilmin 5 . Most live in western New Guinea, a small minority in Papua New Guinea. In this essay, I use the terms Nalumin and Ngalum to refer to the peoples among whom respectively Michel and Hylkema worked. Michel made a return visit to the Eipo in 1986. However, of the team members especially Heeschen has continued to return to the Eipo and also to other Mek speakers, at first working for the Vereinigte Evangelische Mission, the United Evangelical Mission (Heeschen, 1998b: 291). So far he has spent over five years among Mek speakers (1998a: 11), extending his research from linguistics into anthropology and into the ethnography of speaking. He continues to publish about his data adding to, and

4. Michel has published an account of the quakes and their aftermath (Michel, with Koch and Schiefenhövel, 1989). This is a paper accompanying Michel's film « Back to normal life after an earthquake » (1983b).

5. The members of the 1958 expedition to the Star Mountains, just west of the border of what is now Papua New Guinea, also worked among Ngalum. They used names such as Star Mountains people, Star Mountains Papuans, and Sibil people (Pouwer, 1964; Kooijman, 1962). 


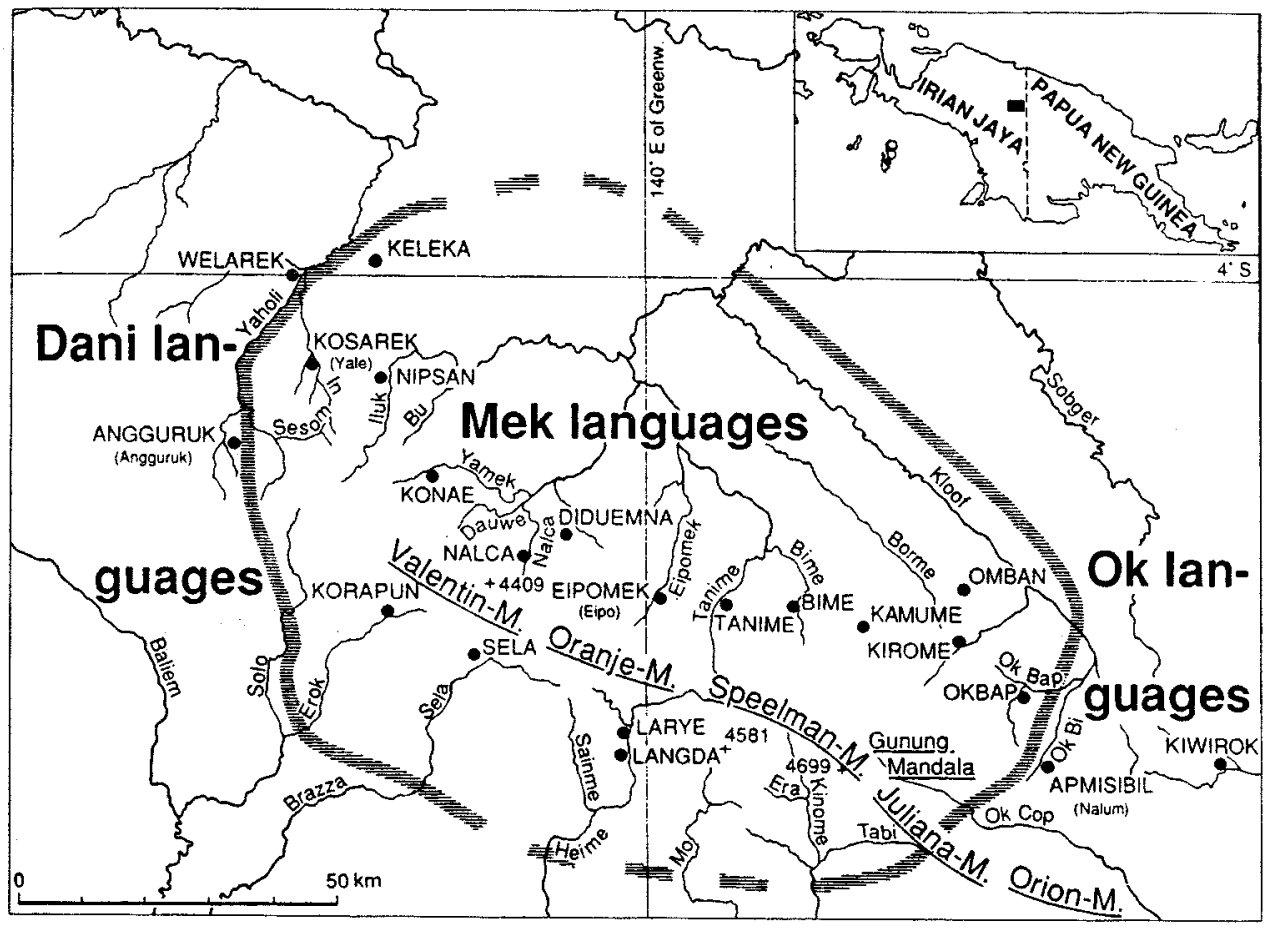

MAP 3. - The area currently inhabited by Mek speakers (Rühlemann, in Heeschen, 1994a: 162)
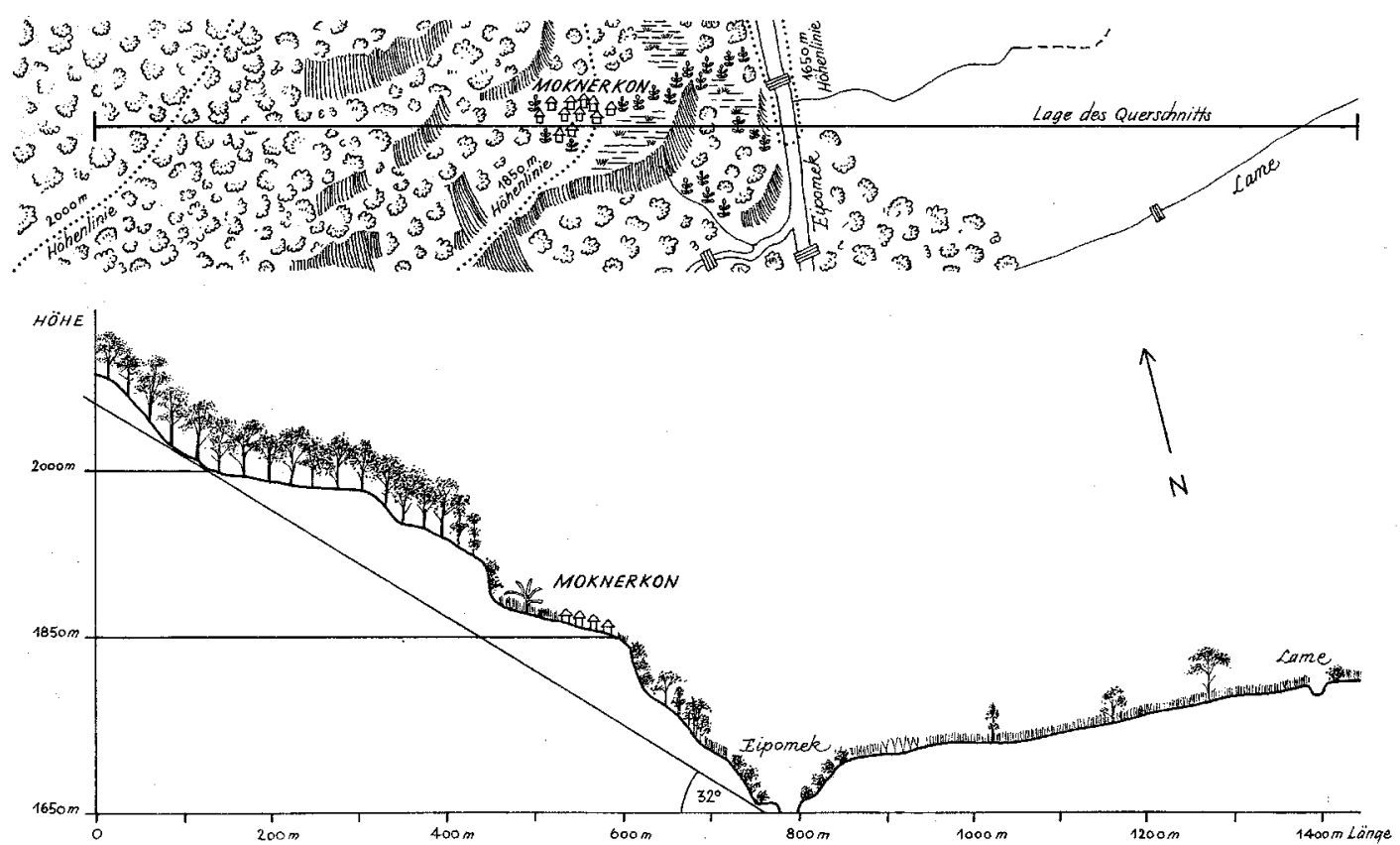

MAP 4. - Cross-section of the upper Eipo valley, at Moknerkon (Michel, 1993a: 44) 
updating, earlier publications. His comparative work highlights the specificities of the Eipo way of life. At the time of writing, in late 2002, he was again carrying out field research. Of the team members, he acquired the greatest command of the Eipo language, enabling him to record, translate and interpret myths.

The arrival of the team in mid-1974 heralded an era of far-reaching changes for the Eipo (Schiefenhövel, 1988a: 70f). Firstly, they had to deal with a group of researchers, talkative people with an abundance of measuring and recording tools, even though the team purposely limited the number of researchers at work at any moment in time (Koch, pers. comm. 2003, see table 2, p. 14). After the first earthquake, the Indonesian government set up a large scale support program in which the researchers took part. Missionaries of the Unevangelized Fields Mission, supported by Western Dani evangelists, started intensive work in the valley in 1978 (Schiefenhövel, 1988a: 70) and at Christmas 1980, the Eipo burnt their objects with religious significance so as to demonstrate their desire to convert to Christianity. As appears below, the conversion entailed that Eipo became far more open about their previous way of life because the secrecy that had pervaded it no longer prevailed. However ambivalent, or critical (Heeschen, 1986b), the researchers may have been about the sudden conversion (cf. Mitton, 1983: 125), their knowledge of the previous way of life benefited from it. At a later stage interest in the pagan mythology was renewed. Heeschen was asked for the texts he had collected and the recordings he had made at the time they were made. $\mathrm{He}$ comments :

" the oral traditions of the Mek have changed; however, not only because they are now written up and because narrators and listeners take pleasure in what has been recorded. With the re-awakened interest of some informants and evangelists for their traditions, they independently start reflecting on, comparing and integrating them: variations are eliminated and improvements inserted. » (1994a: 175)

I have attempted to compile a complete list of the team's publications, including the films. That list forms the first part of the bibliography of this essay. A second part lists the papers of the 1990 Seewiesen conference. The third and last part lists other publications I quote in this essay. As mentioned, the papers and monographs of the MKU series form the most important part of the team's results. Most contain many photographs, some in colour, drawings and maps that are well produced and that complement the texts well.
They have English summaries. Excluding the papers, I briefly note the contents of the monographs, in order of publication.

Hiepko and Schultze-Motel (MKU 7, 1981) consists mainly of a survey of the flora in the Eipo valley, followed by annotated lists of the plants that the Eipo make use of, for whatever purposes. The lists are especially valuable because they include the species used for clothing and finery, for tools, for house construction and so on. Hiepko and Schiefenhövel (MKU 5, 1987), mentioned below, complements the monograph.

Heeschen and Wulf Schiefenhövel's dictionary Wörterbuch Eipo-Deutsch-Englisch (MKU 6) was published in 1983. This is the first MKU monograph with an English text. The introduction is both in German and in English and so are the entries for Eipo words. The entries are extensive: the dictionary is an annotated one. The book includes a bi-lingual guide to pronunciation of the Eipo language and a list of kinship terms, also with German and with English glosses.

Michel's monograph Interdependenz von Wirtschaft und Umwelt in der Eipo-Kultur von Moknerkon [Interdependence of Economy and Environment in the Eipo Culture of Moknerkon] (MKU 11, 1983a) is a doctoral dissertation in anthropology. Michel's theoretical starting point is J.N. Anderson's conception of ecology as " the study of living systems as integrated complexes » (as quoted in English by Michel, 1983a: 8). He employs a broad conception of " economy » and includes religious and ideological aspects in his discussion. Accordingly, his book provides information on a wider range of topics than the title suggests. Michel takes note of the vast literature dealing with the highlands of both western and eastern New Guinea. In his conclusion (1983a: 149), he quotes Sillitoe arguing that his concept of a «balanced society ", coined for the Wola in the Southern Highlands of Papua New Guinea (Sillitoe, 1979: 290), applies to the Eipo as well.

Also Koch's Ethnographische Notizen über einen Siedlungsbereich im oberen Eipomek-Tal, zentrales Bergland von Irian Jaya (WestNeuguinea), Indonesien [Ethnographic Notes about a Neighbourhood in the Upper EipomekValley, Central Highlands of Irian Jaya] (MKU $15,1984 \mathrm{~b})$ provides more information than its modest title indicates. The book is a short ethnography with an emphasis on material culture and economic activities. Hence it overlaps with, but at the same time complements, Michel's discussion. At the time Koch combined his work as a 
museum anthropologist with university teaching. He collected and documented the Eipo artefacts that are now held in the anthropological museums in Berlin and in Abepura, West Papua.

Hiepko and Wulf Schiefenhövel, Mensch und Pflanze. Ergebnisse Ethnotaxonomischer und Ethnobotanischer Untersuchungen bei den Eipo, Zentrales Bergland von Irian Jaya (WestNeuguinea, Indonesien [People and Plants. Results of Ethnotaxonomic and Ethnobotanical Research among the Eipo, Central Highlands of Irian Jaya] (MKU 5) was published in 1987. The authors first discuss Eipo botanical taxonomy, guided by Berlin's characterisation of botanical ethnotaxonomies and by Hays'discussion of the ethnotaxonomy of the Ndumba, Eastern Highlands of Papua New Guinea. In addition they deal with the role of plants in the " mental world» (die geistige Welt) of the Eipo. Their discussion includes a love song, in English translation, that I quote in a following section.

Wulf Schiefenhövel subsequently published Geburtsverhalten und Reproduktive Strategien der Eipo. Ergebnisse Humanethologischer und Ethnomedizinischer Untersuchungen im Zentralen Bergland von Irian Jaya (West-Neuguinea), Indonesien [Social Processes Occurring at Birth and Reproductive Strategies of the Eipo. Results of Research into Human Ethology and Ethnomedicine in the Central Highlands of Irian Jaya] (MKU 16, 1988a). In this book, he presents seven case studies of birth-giving, in one case followed by infanticide, that the mothers allowed him and his wife to follow and to film ${ }^{6}$. Next he summarises the extant literature on infanticide in Melanesia and argues that, contrary to most of the authors he reviews, the Eipo do practise infanticide with a view to population control. He also presents data on Eipo demography. Schiefenhövel uses a considerable number of medical terms, some in Latin, and presupposes some medical knowledge. He quotes from many medical publications. Accordingly, his book seems to address his medical colleagues and attempts to convince them that consideration of Eipo birth practices is medically worthwhile. He did similarly in several papers published in medical journals or conference proceedings (for example, 1980a, 1982b).

Eibl-Eibesfeldt, Wulf Schiefenhövel and Heeschen write that their 1989 monograph Kommunikation bei den Eipo (MKU 19) is a biological study (1989: 13). But because they give a broad meaning to the concept of « communica- tion ", their discussion includes analyses of songs, of the disposal of the dead, and of other rites de passage. Their book thus contains a great deal of anthropological relevance and interest. For Eibl-Eibesfeldt the Eipo study was part of his worldwide research into biologically programmed behaviour sequences (1989: 116) during which he also worked among ethnic groups in Papua New Guinea (Eibl-Eibesfeldt, 1977: 229; Schiefenhövel, Uher and Krell, 1993: passim). The arrangement of topics follows the one in Eibl-Eibesfeldt's massive Human Ethology, also published in 1989. He is the author of the theoretical approach set out in the introduction to the MKU monograph (1989: 6).

Heeschen's 1990b monograph is entitled Ninye Bún. Mythen, Erzählungen, Lieder und Märchen der Eipo (MKU 20). The first two words in the title are in Eipo and mean « friend » or « trade partner». Heeschen uses the terms to make it clear that his scholarly work was made possible by the ties of friendship that linked him with the Eipo. The German words in the title mean Myths, Tales, Songs and Fairytales of the Eipo. The book is primarily a linguistic one, containing a corpus of 135 texts, with interlinear translations, using German words, and translations into German, seemingly keeping quite close to the Eipo originals. But in addition Heeschen wrote introductions for each of the eight sections into which he has subdivided his texts, and he provided annotations, in some cases extensive ones. The introductions and the notes contain a great deal of information about the immaterial aspects of the Eipo way of life. The eight sections deal with: Origins, Initiation, Boundaries, Sociality, Feasts and Dances, War, Songs, and, finally, Fairytales.

Heeschen's A Dictionary of the Yale (Kosarek) Language (with sketch of grammar and English index) (MKU 22, 1992a) is almost exclusively what the title refers to. But it includes a short introduction dealing with the way of life of the Yalenang, a group of western Mek speakers. It is also the first issue of the series that has English as its primary language.

The latest monograph produced is Heeschen's An Ethnographic Grammar of the Eipo Language spoken in the Central Mountains of Irian Jaya (West New Guinea), Indonesia (MKU 23, 1998a). The book also contains a short introduction to the Eipo way of life. It consists of three parts. The first is an intriguing socio-linguistic analysis of the Eipo language and of Eipo verbal communication. Heeschen links characteristics

6. That the mothers did so, resulted, I suppose, also from the fact that Schiefenhövel provided medical care during his stay (1988a: 8; 1988b). 
of the Eipo language, such as its small and apparently rapidly changing vocabulary and the role of location as a linguistic focus, to the function of other semiotic systems: ritual and symbolic activities. He also examines the effects that the small scale of Eipo communities, nevertheless including migrants from other dialect groups, the codes regulating verbal communication and its exclusive orality have on the language. The second part of the monograph deals with Eipo grammar and in the third Heeschen presents a number of texts, especially to highlight dialectical differences between Mek languages 7 . Heeschen is drafting at least one more monograph, bringing together texts from the oral traditions of the Yalenang.

In this essay, I intend to report on and to review the results of the team's work. It seems to me that it has not received the attention it deserves, probably because most of it is written in German. This is regrettable: the team carried out its research programme in an area that is not at all well known, anthropologically and otherwise. Given that I am an anthropologist myself, I am mainly concerned with the ethnography of the Eipo. This accords with the central place that anthropology had in the research programme. Several of the team members, notably EiblEibesfeldt, Schiefenhövel and Heeschen, emphasise the presence of a common biological heredity in human behaviour. That point of view seems inescapable to me. At the same time, what they have published in my view demonstrates that biological and cultural aspects of human behaviour are intertwined to the extent that they cannot be researched separately. Eibl-Eibesfeldt has compiled an enormous range of photographs and films to demonstrate a common behavioural repertoire among humans. He published a small selection, showing the Eipo, in the 1989 monograph that he co-authored with Schiefenhövel and Heeschen. What the photographs show, however, are scenes that are culturally specific. The longer the sequence of interaction shown, the clearer the cultural influence tends to be. Consequently their work contains a great deal that is of interest to anthropologists who do not regard themselves as students of human ethology.

To be of scientific value, Eibl-Eibesfeldt, Schiefenhövel and Heeschen (1989: 17) posit, the photographic materials « must » show unposed behaviour. For this purpose they used a camera with a prismatic lens system that allowed them to direct the camera away from the scenes they wanted to record. While I do not doubt the benign intentions of the researchers, their use of this camera seems questionable to me given that it is a covert instrument of inquiry. Had the researchers told the Eipo how their camera worked and obtained their permission to use it, the matter would have been different. They do not state, however, that they followed this procedure. The researchers concede that their proximity while using their camera may well have influenced Eipo behaviour, but they assume that the people got used to it (ibidem: 17). A comment by Koch supports their assumption. He writes about Eipo at work:

« Wrapped up in their aim to work briskly, they hardly [...] took note of the observer [i.e. Koch]. » (1984b: 7)

At the same time, the comment raises doubts whether the covert method of camera use was indispensable so as to obtain the data desired. If that was indeed the case, it might have been better to relinquish the aim to obtain them. Epstein observes that an anthropologist in the field is not a professional offering a service and so must repect people's right to privacy (Schumaker, 2001: 254). Moreover, some time before the Eipo research took place, Sorenson made a photographic record of behaviour among the Fore, in the Eastern Highlands Province of Papua New Guinea. He does not mention having used a contraption such as used by Eibl-Eibesfeldt and his co-researchers. However, the photographs that he published (1976) do not seem less informative than the ones of the Eipo team.

The scholarly literature about the central highlands of Papua New Guinea is voluminous and wide-ranging, such that Brandt recently assessed it as "Highlandology » (2001: 35f). While writing up the results of their own research, the members of the Eipo team made selective use of the existing literature, also when taking into account that many of their publications date back to the early 1980's. For example, Schiefenhövel surveys the literature on infanticide in Melanesia (1988a: 67f); in his ethnographic grammar of the Eipo language, Heeschen (1998a: 15f) discusses the current state of research into Papuan, Non-Austronesian, languages; and Michel (especially 1983a: 147f) the ecology of the highlanders of Papua New Guinea. But with a number of topics the researchers present their data without making much use of previous analyses. I refer specifically to animal husbandry; to forms of leadership as related to 
other elements of social organisation such as warfare and exchange; to male-female relations (but see Schiefenhövel, 2003); and the relationship between religion and regional organisation. My essay amounts to a mini-ethnography of the Eipo with, in addition, comments on the work of their ethnographers. That the data collected by a large and diverse group of researchers allow the writing of such an ethnography, speaks for the success of the interdisciplinarity that the initiators of the project sought. As touched upon above, the extent to which the team members draw upon the results of anthropological inquiries elsewhere in New Guinea varies. Where I see fit, and according to the extent of my own knowledge, I widen their contextualisation of the Eipo way of life. Initially, in the early 1960 's, I was trained as a British social anthropologist. The bias entailed comes through in what I have selected for presentation and in the way I present it.

\section{The Eipo}

The name Eipo denotes those speakers of the Mek languages living in the valley of the Eipomek, the Eipo River. The Mek speakers live in scattered pockets spread over a number of valleys, both north and south of the central divide (see map 3, Helmcke, 1983; Helmcke, Pöhlmann and Pohlmann, 1983: map inside back cover). Silzer and Heikkinen Clouse (1991: 30, 19-20) put the total number of Mek speakers at about 26,000 to 31,500 . The name " Mek» for the languages and their speakers was coined by Schiefenhövel (1976: 265; Heeschen, 1998a: 16). In the languages concerned, mek means «water», " river» and Schiefenhövel devised the term to distinguish the Mek languages from the Ok languages further east that are likewise named after the term for water or river. The term Mek is also the name of a tree species that was mentioned in almost all myths and that was believed to be a place where ancestors appeared (ibidem: 15, n11).

Heeschen reports that the Mek languages are « relatively isolated», while they show great similarities. Linguists have grouped them into a sub-phylum (Heeschen and Schiefenhövel, 1983: 5). The physical anthropologist Büchi (1978; 1981) noted that also genetically the Mek speakers form a rather isolated group. He concluded similarly about the Eipo, pointing to their short stature, with a small standard deviation. Given that on average the Eipo, also the men, were no taller than $150 \mathrm{~cm}$, several team members refer- red to them as «Pygmies » (Büchi, ibidem; A. Simon, 1978; Heeschen, Schievenhövel and EiblEibesfeldt, 1980: 142; Koch, 1984a), without, however, subscribing in any way to the « Pygmy mythology » identified by Ballard (2000). The Eipo gene pool indicated frequent intermarriage. In, and near, the Eipo area Mek speakers were aware of their linguistic differentiated and they distinguished dialects referring to the term for the expression "what is that" (Michel, 1983a: 18-9). The dialect of the Eipo was spoken along only part of the river valley in which they lived. Downstream, from the village Firwan onwards (see map 2 in Helmcke, Pöhlmann and Pohlmann, 1983), people spoke a different dialect and the river had a different name (Michel, ibidem).

Helmcke opines that it was typical for Mek speakers to live in sizeable villages. About the people living in the Sulo, or Solo, valley west of Korapun (see map 2), he writes that they were not Mek speakers, because they lived in scattered settlements (1983: 39). The team focused on their work with the upper Eipo, settling in different villages. In this essay, I refer to this area as the « upper Eipomek valley ». Helfrich settled and worked among Mek speakers in Talim, a tributary valley of the Eipomek, just downstream of the upper Eipo habitat. G. and U. Konrad worked in Bime, east of the Eipomek valley. However, the team did not cover the entire population of the " area of intensive research » indicated on map 1. In the " area of extensive research » team members worked especially in the northwestern corner, among the Yale, Mek speakers in the Im valley and valleys nearby. In early publications, Heeschen (1992a: 6) called them Imlang (see map 3). He now prefers the term Yalenang, an endonym (Appell, 1968) and in the remainder of this essay I follow Heeschen's more recent usage. $\mathrm{He}$ published several valuable comparative papers (1984a, 1994a, 1994b, 1998b). The team has not published anything about people living in other parts of the area of extensive research.

The first Europeans to encounter Mek speakers were members of the Dutch colonial army, accompanied by the British naturalist Meek. In the course of the military exploration of New Guinea they had, in 1911, entered the highlands and met New Guineans who, it appeared later, were Mek speakers. A.C. de Kock, the commanding officer, published a paper about his findings (1912) and, recently, Godschalk $(1993,1999)$ has published an English translation. Other researchers who worked among Mek speakers are Godschalk and Andrew and Anne Sims. Godschalk, then a missionary, worked in the Sela 
valley, south east of the Eipo and south of the main divide, from 1980 (1993: xiii). From 1981 to 1992, Andrew and Anne Sims carried out linguistic research for the Summer Institute of Linguistics among the Ketengban, Mek speakers living to the east of the Eipo (1992: x). Their publications (Godschalk, 1993; Sims and Sims, $1992^{8}$ ) add to the anthropology of the Mek speakers. They make it clear that, whatever the homogeneity of the Mek languages, the speakers of these languages follow or followed appreciably different ways of life. In the following, I discuss the results of the German team's research. I do this under four main headings. The first is « habitat», the second « social organisation », the third " hostilities » and the last one « the Eipo and their neighbours ». I end with a short conclusion.

\section{Habitat}

The members of the German research team did most of their work in the upper Eipomek valley, in a number of villages (see map 2). They use the terms Dorf, village; Weiler, hamlet; Siedlungsbereich (Koch) and Siedlungseinheit (Michel), neighbourhood. I prefer to use the latter term since there were cases that several settlements formed a single socio-political unit. Koch (1984b: 22-23) suggests that the political relations between neighbourhoods and settlements were fluid. In view of the variable size of the actual settlements, I refer to them by the terms « village » and " hamlet ». At the time the research took place, there were six neighbourhoods in the upper section of the valley, inhabited by altogether about 640 people, with a range per neighbourhood of 52 to 190 (Michel, 1983a:
19; see table 2). Michel calculates population density at six persons per $\mathrm{km}$. Schiefenhövel (1988a: 72-73) presents slightly different figures. He comments that the number of inhabitants is small compared with inhabited valleys further east, such as the Wahgi, and further west, such as the Grand.

The data for Munggona, Kwarelala, Talim en Malingdam are from Röll and Zimmermann (1979: 6); those for Moknerkon from Michel (1983a: 23); and those for Dingerkon from Heeschen (1990b: 11; 1998a: 22). Heeschen writes that Dingerkon in the mid-1970's had « about 60 inhabitants $»$. He does not differentiate by sex.

Valley .and the valley of the North Baliem. The altitude of the Eipo settlements ranged from about 1600 to just over 2000 metres (Koch, 1984a; Koch, 1984b: 11). Even though map 1 includes a long stretch of the Eipomek valley in the area of intensive study, the inhabitants of the six neighbourhoods may well have been a minority of the Eipo speakers. That conclusion is tentative. While Silzer and Heikkinen Clouse (1991: 48) distinguish a separate Eipo language, with about 3,000 speakers, suggesting that all of them were living in the Eipomek valley, Heeschen writes that the Eipo shared a language with the inhabitants of the adjoining valleys (1998a: 22-23). He estimates that there were about 400 speakers of the Eipo dialect in the mid-1970's.

In villages, as well as «men's houses » and « family houses », there were "women's houses » which women used when menstruating and just before and after giving birth. Men's houses tended to be located in the centre of settlements (Koch, 1984b: 18-9; Koch and Schiefenhövel, 1987: 138), women's houses at the periphery. The other structures were built close together and

\begin{tabular}{llcc} 
& & \multicolumn{2}{c}{ number of inhabitants } \\
Neighbourhood hamlet & names researchers & 76 & female \\
\hline Munggona & G. and W. Schiefenhövel & 39 & 23 \\
Kwarelala & Röll and Zimmermann & 78 & 56 \\
Talim & Helfrich & & \\
Dingerkon & Heeschen & 28 & 24 \\
Moknerkon & Michel & & \\
Malingdam & Koch & 60 & 52 \\
Imarin & & 16 & 18 \\
Mumyerunde & & 23 & 19 \\
Kabcedama & & &
\end{tabular}

TABLE 2. - Size of Neighbourhoods and Hamlets 
without apparent order (Röll and Zimmermann, 1979: 8, and village plans on 9-11; Michel, 1983a: 24). Men's and women's houses were similarly constructed, but men's houses were larger and more elevated. Houses were of a light construction. Michel notes that roofs were often leaking (1983a: 27). Many houses were quite crowded, allowing the inhabitants less than $1 \mathrm{~m}$ floor space (Koch, 1984b: 38; Michel, 1983a: 25; Schiefenhövel, 1989b). Both authors, however, state that Eipo liked being physically close, also while outside. For them, Heeschen (1984: 117) argues, being at close quarters was part of a good life. The impression that also other ethnographers give is that the people appreciated the small scale of their social life and that they lived face-to-face rather than back-to-back ${ }^{9}$.

Men's houses were named and many villages had more than one. Eipo perceived a hierarchy of socio-religious significance among them. Some had no particular significance at all, in contrast to those in the villages that people regarded as the original ones for specific clans or sub-clans ${ }^{10}$. In the upper Eipomek valley, the men's house in Munggona, named Binalgekebnaik ${ }^{11}$, had the highest rank. It possessed supralocal importance. Michel (1990: 5) writes that it was known among Ok speaking Nalumin just across the border with Papua New Guinea. Yet, Eipo men's houses were not integrated into a regional cult, as was the case among the easterly Ketengban (Sims and Sims, 1992: 31-2). The authors do not state why Binalgekebnaik was so revered. A reason might be that people thought that Munggona was an old village. Also, the house contained an important relic, a sacred digging stick. Eibl-Eibesfeldt, Schiefenhövel and Heeschen (1989: 140) write that this relic was believed to be an instrument of creation. It is noteworthy that the authors here report yet another idea accounting for the creation of the contemporary world. After the digging stick had emerged from mount Binal, south of the Mek basin, in the main divide, it created ridges and valleys and made the earth suitable for human occupation. Michel (1983a: 66) writes that also in other men's houses digging sticks were held as sacred relics. Eibl-Eibesfeldt and his two co-authors opine (ibidem) that their presence in men's houses symbolised the appropriation by men of human culture, even though it was a tool that women used more than men. In line with the evolutionary cast of their ethnography, they add that it might also symbolise the shift from a collecting to a food producing way of life. Against these arguments, I point out that, with or without sacred relics, the existence of separate men's and family houses set men apart from the other members of the group. And, as for instance Golson and Steensberg (1985) and Sillitoe (1988: 73f) have shown, in the highlands of New Guinea also men used digging sticks, although usually of larger size than those of women (cf. Koch, 1984b: 75).

J. Weiner describes the Foi, living in the Mubi valley, south of the central highlands of Papua New Guinea, as living in an intermediate position between the highlands and the lowlands, ecologically, geographically and culturally (1988: 19). By contrast, in the last quarter of the 20th century and in the different ways that Weiner mentions, the Eipo were the people closest to the mountain tops, with the upper limits of their habitat adjoining uninhabitable mountains. Eipo favoured living at this altitude, notwithstanding the cool climate and the high rainfall and notwithstanding Heeschen's observation (1990b: 21) that they held on to ritual objects, such as sago leaves, suggesting a lowland past (see also note 14). They avoided visiting areas at altitudes below 1000 metres (Michel, 1983a: 14). The scant evidence available suggests that the Eipo have been for some time the people closest to the mountains tops. At the time of the fieldwork, they did not easily shift their villages (Koch, 1978c), given that they wanted to rebuild sacred men's houses at the same location and among the houses of a settlement. Sometimes people shifted because they were forced to flee, as were the villagers of Moknerkon, the village where Michel has worked.

The various authors document three population shifts. One followed the rout of the inhabitants of Walubok, some of whom later founded Moknerkon (Michel, 1983a: 19f; see map 4), another the founding of Malingdam (Koch, 1984b: 11) and the third the founding of Kwarelala (Röll and Zimmermann, 1979: 16). All three were up-valley, in accordance with the preference for a cool climate. As appears below, also the myths of origin held that settlements had existed from the beginning of human existence. And accounts of fights referred to them taking place in the Eipomek valley (Heeschen, 1998a: 21). Fieldwork data show that the Eipo tended to return to fallow garden land when making new

9. I can recollect that I have read the expression « back-to-back » in a scholarly publication, but I do not remember which one.

10. Helfrich (1978c) calls them Stammdörfer, stem villages

11. Or: Binalgekebn aik, « aik » being the Eipo word for « house ». 
gardens. In accordance with this fieldwork observation, aerial photographs taken in the last phase of World War II show that the upper Eipomek valley was then inhabited (Helmcke, 1983). However, the photographs predate the team's research by only 30 years.

Eipo viewed their habitat as a sacred domain, made habitable by the creative actions of ancestors. My use of the term "creative " requires elucidation, because Steward and Strathern (2001: 79) reserve the term «creation» for « events [related in stories] that initiate a new state of affairs in historical terms. [They leave] room in principle for creations later ». Steward and Strathern contrast this category of events with « origins ", « events that lay down a permanent state of affairs » (ibidem). In their conceptualisation, the actions that the Eipo ascribed to their ancestors constituted origins rather than creations. While in my view Steward and Strathern made a valuable distinction here, their choice of the two terms seems arbitrary. Accordingly, I used their distinction while drafting the current text, without, however, using the terms « creation » and " origins » in the meanings they propose $^{12}$.

Heeschen (1994a: 175f) describes the landscape, as the Eipo perceived it, as a "mnemotope ", a term he borrows from the German anthropologist Assman. Ancestors emerged from mountains, of which most are visible from the Eipomek valley (Heeschen, 1994a: 166-167). When they emerged from the ground, they were not like present-day humans: " they were unfinished, small, dirty, had animal bodies and were in need of help. They were carried by marsupials, but also by sacred objects such as kelabi shields ${ }^{13}$ or the first digging stick » (Heeschen, 1994a: 167). They were wanderers and experimenters, each of them staying on the move, changing the environment, solidifying and stabilising it, making the earth fertile and letting plants grow. Each of them cohabited with an animal -or, more precisely, an animal to be- that, in time to come, became a totem for his patrilineal descendants, the members of a clan. Then, each ancestor found a spot for building a men's house and settled down (Heeschen, 1990b: 19-21). The ori- gin myths were precise about the specific routes that they took. Heeschen (1994a: 168) writes that the shorter ones can be followed on present-day maps ${ }^{14}$. They were also precise about the locations where the ancestors stopped their wanderings and built their men's houses because these locations became the centres of the clan territories into which the valley came to be subdivided. Men's houses remained visible testimonies of the era in which things got literally sorted out and the environment acquired its present form. In Heeschen's words:

« When people emerged from the ground the most important thing they had to do was finding and readying a place for a men's house. It is the only place that secures life and growth [...]. The men's house is not only the "spiritual » centre of the clan, but also the centre of [its] habitat [...]. Villages, gardens and forest are situated around the centre as if in concentric rings. » (1990b: 143)

Eipo referred to constructing a men's house with the expression «building in the centre » (Heeschen, 1990b: 143). Heeschen (ibidem) found that the origin story of a clan and the construction story of its men's house showed great similarities. And among the sacred objects held in men's houses are relics of the bodies of ancestors. The image of concentricity that Heeschen here evokes, recalls Pouwer's conclusion about the importance of the " circle » of relatives (1964: 147) in Star Mountains social organisation. Hyndman (1991) similarly argues for the importance of concentric territorial organisation among the Ok-speaking Wopkaimin, across the border with Papua New Guinea.

The sexual relations of the ancestors in the course of this formative era produced a number of differential food taboos. The most striking one was that for a sizeable proportion of Eipo pork consumption was forbidden. These clanspecific taboos formed part of a larger corpus of food taboos. Others were gender-specific: most birds were not to be eaten by men; cassowaries not by women. Nor were they allowed to eat oil pandanus. Yet another category concerned the diet of boys being initiated. Schiefenhövel comments (pers. comm. 2002; 1976: 268) that the

12. The paper by Steward and Strathern appeared in Emplaced Myth, edited by Rumsey and Weiner (2001). I acknowledge the stimulus provided by several other papers in the book, although I do not quote them in this essay.

13. Kelabi shields are painted boards that some Mek speaking groups, but not the Eipo, used to close the doors of their men's houses (cf. Craig, 1988 and 1990, for the Ok speaking peoples). There were also kelabi that were used for fertility rituals in times of food shortage. Kelabi were believed to have been cut from the Mek tree (Heeschen, 1994b).

14. The account Heeschen presents in his 1990b monograph is at some points at variance with the argument in his 1994a paper. In the monograph Heeschen had concluded that the creation myths refer to a trek into the mountains, 'along the rivers' (1990b: 21). It seems equally possible to argue for a mountain origin given that ancestors were believed to have emerged from mountains. A more telling argument in favour of a lowland origin is that at least some of the sacred nets held in men's houses contained remnants of sago leaves (Heeschen, 1990b: 98-9). See also Heeschen, 1998a: 21. 
taboos entailed that many protein-rich foods were reserved for women.

Heeschen has provided the above account as a result of his collecting oral texts. Other members of the team present information that complicates how Eipo imagined how they came into being. Firstly, Michel (1983a: 40) reports that members of different clans claimed that their ancestors originated from such objects as a taro variety or other cultivars, a tree species, a specific river, a possum species, the sun and the moon. In these reports people claimed that they originated from entities occurring in their current environment and from very specific ones. They seemed to grant their ancestors a smaller creative role than did Heeschen's spokesmen. Furthermore, Uwok, a middle aged man, told Michel (1983a: 41) that some people, and also pigs and dogs, the only domesticated animals, originated from stones that had been moved along in the rivers and had been left lying on their banks. These were big stones, the smaller ones having been carried further by the water. Hence Uwok professed ignorance as to how people downstream had come into being ${ }^{15}$. Finally, Hiepko and Schiefenhövel (1987: 5) quote from an Eipo myth «It was the tree that bore people ». I take it that the authors view the statement as a metaphor signifying the importance of trees and plants in Eipo life, but it lends itself to further elaboration adding to, or revising, other ideas about their genesis.

It is noteworthy that Godschalk (1993), writing about Mek speakers in the Sela, south of the main divide, points to a situation having features similar to that which obtained among the Eipo. There were several strands in the traditions about the origin of the people. One is that they originated from the mountains, or appeared from mountain caves. Another was that $t$ hey came into being when a pig was cut up. Yet another was that they were formed from the leaves of a primordial tree. These themes were sometimes closely interwoven (1993: 95). A taboo on eating pork applied only to inhabitants of the Weip valley, in southeast Sela (Godschalk, 1993: xvii, 33). The existence of a plurality of myths accounting for human origins (see also note 15), as seems to have existed among the Eipo in the mid 1970's and among Mek speakers in Sela, is in my understanding not uncharacteristic of New Guinean ways of life. What seems to matter, however, is that the different versions all placed the genesis of contemporary Eipo in familiar surroundings, if not the Eipomek valley itself.
A second complication is that clan members have spread over many valleys so members of clans and sub-clans with different migration and origin traditions often lived together in a single settlement. Michel reports the places where, according to the Eipo, clans originated. $\mathrm{He}$ (1983a: 40) mentions ten clans. A minority was said to hail from the Eipomek valley, with the others coming from areas to the northwest, the northeast and the south, across the main range. Eipo told him that the scatter of clan members was considerable (1983a: 40). According to Wulf Schiefenhövel, members of the same clans were found among speakers of different languages (Michel, 1983a: 39, n37). Helfrich (1978c) writes that local Eipo « clans » are in most or all cases actually sub-clans. That view seems correct, but I follow here the terminology of the other team members.

Thirdly, as I mentioned above, Heeschen complemented his Eipo research with work among Mek speakers living west of the Eipo, in a tributary valley of the Jahuli river, living at the northwestern extremity of the Mek territories (see maps 1 and 3). He refers to them as Yalenang, " easterners », apparently an exonym (1984a: 114 n4; 1992a: 7-8). Heeschen concludes that these people have come from the east to their current habitat. They too posited that their ancestors emerged from mountains in the Eipo area. Unlike in the case of the Eipo, for the Yalenang it mattered which route the ancestors took to arrive at their current habitat. This was because descendants were entitled to claim sites along the route that their ancestors followed. The Yalenang clan names that Heeschen records in his paper were different from those on the short list in Michel's monograph (1983a: 40). So it may be that entire clans migrated away from the Eipomek valley and/or its environs.

The impression that Heeschen (1990b) gives is that the Eipo emphasised mythology at the expense of history. In their recollections of the past, they viewed the creation era as the most important formative period, the only episode in an episodic conception of the past. In a paper comparing the ways of life of the Eipo and the Yalenang, Heeschen (1984a) reports that these people have made their village history into a myth similar to the one that Heeschen relates for the Eipo, with the settling ancestors making the area suitable for human livelihood.

What distinguished Heeschen's version of the Eipo creation myth from those of neighbouring Mek speakers was that, according to the Eipo,

15. Heeschen (pers. comm. 2002) comments about these two alternative traditions that each of them is given credence by one sub-clan only. Nevertheless, that makes them available and people may adopt them when they see reason to. 
each of their founding ancestors was responsible for a part of the creation, although they had given some ancestors a creator role that made them culture heroes for most, if not all Eipo (Heeschen, 1984a: 124). Among the Yalenang, people held all of the founding ancestors responsible for the entire creation. But the easterly Ketengban, also Mek speakers, ascribed their existence to a primordial pig rather than to founding ancestors. At a crisis point in their early existence, the killing of this pig, as he had himself instructed, turned matters around. While dying, the pig went around Ketengban country marking the locations of future ritual men's houses and of initiation houses (Sims, 1992: 33f). The sacred domain that he thus created covered several valleys and united thousands of people, many more than there were inhabitants in the Eipo valley.

Eipo did not subdivide the period of time since the creation into phases separated by significant socio-cultural changes, even though at the altitude at which they lived, the introduction of a crop such as the sweet potato must have greatly changed their livelihood. I mention this because recently Wiessner and Tumu (1998) and Ballard (1998) have demonstrated that peoples such as the Enga and the Huli do remember their past as one replete with change. Heeschen (1990b: 260f) and Michel (1983a: 19f) do present bits of Eipo history by means of stories about fights and wars and ensuing migrations. Heeschen (1990b: 260) comments that such tales were a specific communicative genre, but he adds that Eipo viewed fighting as part of the human condition. So it appears that they viewed it as a phenomenon that had occurred continually since the time the ancestors had emerged from underground (Heeschen, ibidem).

The regime that the ancestors had established still held sway when the German researchers started work. In the course of their stay Binalgekebnaik, the men's house in Munggona, had to be rebuilt. People prepared the material required beforehand; disassembling the existing, quite ramshackle men's house and subsequently building the new one took one day (Koch, 1984b: 52-4). The house was erected on the site of the previous one and materials of the old house were incorporated into the new one to ensure continuity (Koch and Schiefenhövel, 1987: 143, 149; a narrative of the proceedings by a Mek speaker is published in Heeschen, 1998a: 370f). It was a festive, " hectic » occasion that brought participants to « extreme euphoria » (Michel, 1983a: 131). Men broke into dance while carrying building materials to the construction site. The film that Koch and Schiefenhövel (1979) made of the construction confirms Michel's observations (also the picture in Schiefenhövel, 1993a: 28-29). Moreover, it shows a massed group of men at work in the limited space available for the men's house and thus gives a vivid impression of the clumpiness of Eipo villages. The men seemed to know exactly how to perform their tasks. They did so in a co-ordinated manner, without being directed by a supervisor or leader. A critical moment was when a prominent man carried the sacred digging stick, carefully wrapped in leaves to hide it from view, to the new house. He did so in extreme slow motion so as to prevent the stick from suddenly moving since that might bring about a life-threatening storm (Koch and Schiefenhövel, 1987: 148, 153-154). Since Binalgekebnaik had exceptional religious significance, people who lived in other villages in the Eipo valley and from farther afield took part. Hence participants included members from other clans. House building was followed by a communal meal with quality foods such as taro and pork. Koch comments (1984b: 49)

« Men's houses are of a relatively light construction and their assemblage proceeds quickly. They were nevertheless again and again patched up and even shored up for months, before people built a new one. Possibly they saw such an activity as risky experimenting with the continuity of the most important institution in their villages. »

The rebuilding of this men's house took place on November 26, 1974. It must have been a shattering experience when it was destroyed in the earthquake, just over 18 months later. For months inmates searched the loose soil downhill from the former village site for remnants of the sacred objects; however, in vain (Koch and Schiefenhövel, 1987: 142) ${ }^{16}$.

It was no coincidence that men were moved to ecstatic dancing during the reconstruction of Binalgekebnaik. Dancing referred to the creation. In that era dances expressed requests for seedlings and artefacts directed to the mountains that bore people, and to the ancestors. Contemporary dance leaders impersonated ancestors

16. In Pouwer's description (1964: 134f), territorial organisation among Ngalum living south of the main divide and the way they imagined their sacred men's houses shows many similarities with the Eipo data. These Ngalum perceive an order of seniority among settlements, with the oldest containing a sacred men's house. Pouwer quotes his Ngalum sources telling him: « The iwol [sacred men's house] has always been there and will always remain there. » He adds: « The actual creation of new [sacred men's houses] is admitted reluctanty, if not denied outright » (ibidem). 
and costuming for a dance entailed revitalisation (Heeschen, 1990b: 224).

The entire Eipomek valley was partitioned into clan territories. In Michel's words:

«In the world view of the Eipo, people, animals, plants and environment become complete in one, encompassing conception. » (1983a: 150)

In his next sentence, he applies to the Eipo, in German, a comment by Barth on the Ok-speaking Baktaman. Barth's English original was:

« village cult, garden agriculture, and forest hunting are regarded as different refractions of the same reality and each is manipulated to achieve effects in the other. » (Barth, 1975: 38)

People shared their habitat with ghosts and spirits. Michel (1983a: 41) argues that they saw ghosts and spirits as part of the material world, carrying out the same activities as humans. People believed that they wanted to interfere in human affairs. To protect themselves people followed procedures similar to the ones protecting them from other humans.

The Eipo practised double, sometimes triple, disposal of their dead. The first stage was that the deceased's corpse was placed high in a tree or on a platform not far from the villages (Michel, 1989c). It was wrapped in floral matter: leaves, grasses and tree bark. Subsequently, the corpse might be taken to a garden house. Finally, parts of the skeleton, especially the skull were placed in an ossuary, often in a rock shelter in the territory of the neighbourhood. Parts of the remains of particularly meritorious men -a skull, a hand, a mummified arm-might be added to the relics kept in the men's houses, in cases apparently many years after his death (Michel, 1988a: 235) ${ }^{17}$. Thus, the corpses of the deceased remained in the immediate environment (Koch, 1984b: 130f; Eibl-Eibesfeldt, Schiefenhövel and Heeschen, 1989: 192f). The presence of ancestral remains in the men's houses suggests that, for the Eipo, material presence entailed immaterial support.

The prime element in Eipo religion was the ancestor cult. Ancestral support was deemed necessary for the favourable growth of young men and crops. In addition, ancestral ghosts, especially the ghosts of the recent dead, had to be kept in their abodes which people tried to bring about by gifts and by sacrifices (Heeschen, 1990b: 144). They also periodically revitalised ancestral relics by anointing them with pig fat (Helfrich, 1978b). In addition, they recognised the existence of a heterogeneous variety of spirits, of various degrees of malevolence. Michel (1983a: 41f) mentions: spirits living near the entrance of houses, forest spirits, the spirit (singular!) of misers, a female spirit, named Kerem, the spirit of pigs, of dogs, a category of nature spirits, a spirit of the rainbow, a spirit of the mist. Michel is brief about these spirits, suggesting that for the Eipo some, or many, of them were hazy phenomena ${ }^{18}$. Several areas in the Eipomek habitat were home to spirits. They were not cultivated (Michel, 1983a: 60). It is striking that Michel does not name the Geisterfrau, " the woman of the spirits », the spirit that is most prominent in Heeschen's Eipo publications (esp. 1990b: 110f), whereas Heeschen does not mention Kerem. It does not seem likely that the Geisterfrau is the spirit Kerem, since Heeschen associates her with the mountains that gave birth to the ancestors (1990b: 224). In his 1990 Seewiesen paper, he presents the spirit women - plural- as ancestresses associated with the mountains that bore the ancestors. The fact that in his publications he refers both to a "spirit woman » and to « spirit women » again suggests the haziness that van Baal wrote about. It seems to me to be a phenomenon to be distinguished from the abovementioned plurality of religious traditions that existed with regard to origins. That plurality reminded me of Wiessner and Tumu's statement about the Enga that their ancestral cults « at the time of contact [formed] a veritable collage » (1998: 212).

To end the discussion of " habitat », I present two separate pieces of information that demonstrate how closely the Eipo associated with their living space, especially with its flora. Hiepko and Schiefenhövel (1987: 5) write how human life was, literally, embedded in the world of plants. When a child was born, its mother let it slip into the leaves of balting, a fern species (Cyathea pilulifera) (Hiepko and Schultze-Motel, 1981: 19). When a person died, the corpse was put in and bound to a tree crown, for instance of a kebyal, a casuarina (Casuarina oligodon) (Hiepko and Schultze-Motel, 1981:31), wrapped in grasses, leaves and/or tree bark.

In the same monograph, Hiepko and Schiefenhövel present a love song that Oleto, an Eipo woman, a young widow (Schiefenhövel, 1998b: 127), wrote, composed and sang on leaving her husband and taking up with another man. It was translated by Heeschen (1990b: 328f),

17. In the example that Michel gives a skull was put in the men's house about 25 years after death had occurred.

18. I use the term « haziness » intentionally since van Baal has used this term to characterise many Melanesian religions. He mentioned it to me when discussing the religion of the Apmisibil Ngalum, as described by Hylkema. 
Schiefenhövel added interpretative notes and the poet Fred Turner, writing in English, reworked Heeschen's translation into a poem (Hiepko and Schiefenhövel, 1987: 20f; Schiefenhövel, 1999: 275). Since it is an English text that may go unnoticed, I quote it here in full

By ferny limb, by curly tree

I heard one say, I heard one say,

"What's thine is mine and is not thine ",

I heard her say, I heard her say

5 Lost will I be and far away.

« My curly limb! My ferny-tree! »,

I heard her say, I heard her say.

Friends and gossips! Old companions!

Lost will I be and far away.

10 " Oh curly-heart, o housey-home »,

I hear me say, I heard me say.

With thine axe thou smeared the slim-tree,

cut and tore the rooted wild-tree;

tending my garden I would be.

15 Wild weed by the threshold, wild growth by the door.

Lost will I be and far away.

Thy clever axe will strike and tear;

here, come and fell the quick elm-tree!

I'd know thy flesh, and root it up, pull thee onto me.

20 The flesh-bracelet, pulse-fireband, flame-vine, snap it from thine arm! Wild eat, weed-grass, wild growth by the door, I'll twist thee free, I'll pull thee free.

And lost, my sisters, friends, I be.

25 Lost will I be and far away.

I'll know thy flesh; thou'lt groan for me.

Gossips and sisters! Oh my friends!

The pulse-bracelet, the wrist-vine,

Bite it and burn with alchemy!

30 And as the fruit-vine climbs the tree, I'll clamber, my housey-home, and stay, long-legs, wild growth, at home in thee.

The man with whom Oleto had eloped, lived in a hostile village in the Famel valley (see map 2). Hence she repeats the line " lost will I be and far away ». The first clause probably refers also to the tangle of emotions. The Eipo text contains references to a number of tree and plant species, in line 1, referring to her partner's body, in lines 12,13 and 14, possibly referring to his bodily strength. Lines 28 and 29 refer to fire making by means of a fire saw, a metaphor for love making (Hiepko and Schiefenhövel, 1985a: 21) ${ }^{19}$.

\section{Livelihood}

The Eipo lived predominantly off agriculture and collecting. There was hunting, but it did not yield much, given the paucity of game in the neighbouring forests. At this altitude game is not numerous, moreover Blum argues that overhunting had depleted their numbers (1979: 5). At the same time he states that the people had not exterminated species (1979: 4). He does not substantiate these conclusions. By collecting, I refer firstly to the catching of small creatures such as insects, lizards, mice, tadpoles and so on. Many of these creatures were taboo for men. Moreover, men were not allowed to eat most bird species. Gardens were made up to 2200 metres (Koch, 1984b: 90). For Moknerkon neighbourhood Michel (1983a: 56f) describes four types gardens. The first type was made by clearing virgin forest, or long established regrowth. Cleared vegetation was burned. The labour invested in these gardens concerned mainly the cutting of the forest. The second type consisted of gardens made on gently sloping ground covered by early regrowth or by anthropogenic grassland. The Moknerkon tilled the soil into low beds that followed the contours of the slope. Cleared vegetation was used in constructing the beds: branches for retaining the soil, leaves and twigs for composting. The third type was made on steep slopes, of about $40^{\circ}$, sometimes even steeper. There, the Moknerkon built rough retention fences along the contours of the slope, more or less perpendicular to it. They filled up the hollow between slope and fence with cleared vegetation and put soil on top (see Plate, p. 24) to make a garden bed. Some of the slopes people selected were so unstable that landslides occurred while they attempted to prepare a garden. The fourth type were wetland gardens on swampy, flat land, drained by ditching while the soil dug up was put onto roughly square or rectangular beds. In Heeschen's view (pers. comm. 2002), the more regular outlay of these gardens may have been a recent innovation due to contacts with Dani. It is to be noted, however, that in the mid-1970's, when Michel and Koch made their observations, contacts with Dani were sparse and indirect.

Röll and Zimmermann (1979: 19), who were based in Kwarelala, mention only the last three types, thus excluding gardens made on virgin land. For neighbouring Malingdam, Koch (1984b: 93-94) mentions the second and third type of gardens. He mentions that the Malingdam more often made gardens in areas with secondary vegetation (1984b: 97; Koch and Schiefenhövel, 1989: 9). With these gardens and with the wetland gardens most labour was invested in soil preparation. The tools that the Eipo

19. Oleto's brothers did not « tolerate » her elopement and brought her back to her Eipomek settlement. This move renewed war between the two groups (Schiefenhövel, 1998b: 126f). 


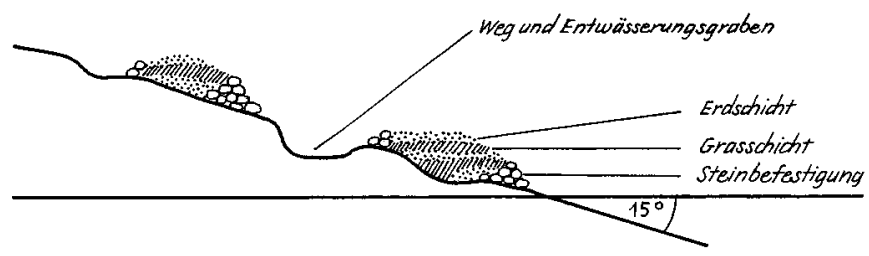

garden beds on gentle slopes

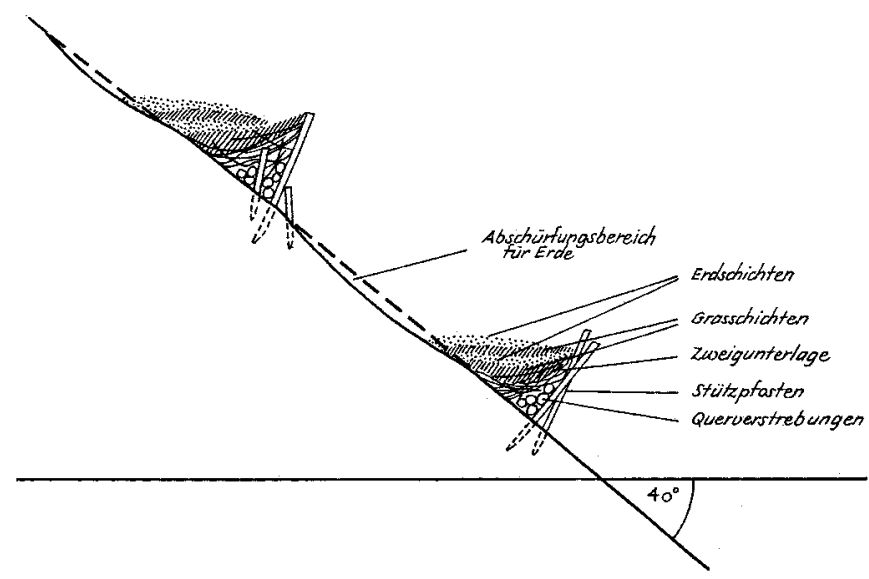

garden beds with supporting poles on steep slopes

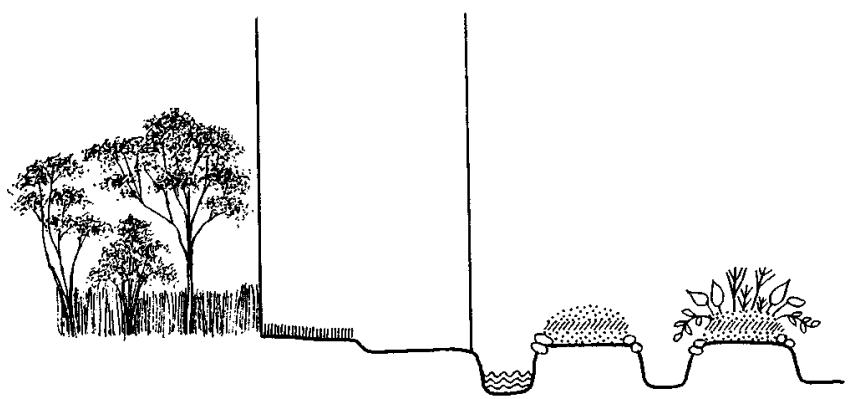

stages of drained garden-making in swampy areas

left: regrowth after 15 years fallow

centre: removal of vegetation right: fashioning beds

Plate. — Types of Eipo gardens drawn by G. Wittner (Michel, 1983a: 8n, 57-59) 
Key to the German words occurring in the plate opposite

Weg und Entwässerungsgraben
Erdschicht
Grasschicht
Steinbefestigung
Abschürfungsbereich für Erde
Zweigunterlage
Stützpfosten
Querverstrebungen

used making gardens were stone ones, mainly if not exclusively adzes, and digging sticks of varying sizes (Koch, 1984b: 75, 133). Koch records that Eipo mostly worked by themselves, or in the company of their spouse. In cases in which the inmates of a men's house decided to work simultaneously on the same track of land, they worked in that part that was to become their own garden (1984b: 98).

When discussing the agriculture of the $\mathrm{Ok}$ peoples, Hyndman and Morren characterise their agriculture as « outfield »-oriented. They write:

«Thus 'infield-outfield' agriculture, involving ditching and mounding of swampy flatlands in combination with swiddening of forested slopes, so characteristic of the centres on the Eastern and Western spheres is impossible at Ifitiman. » (1990: 20)

With the expression "Eastern sphere » they refer to most of the highlands of Papua New Guinea, east of the Strickland; and with « Western sphere » to the highlands of western New Guinea, from the Grand Valley of the Baliem westwards (1990: 13). They conclude that Ifitiman is the original centre of the Telefolmin people, in the centre of the habitat of the Ok peoples (1990: 21). Pouwer describes agriculture in and near the Sibil valley, in the Star Mountains, in between the border with Papua New Guinea and the territories of the Mek speakers as equally outfield-oriented:

« shifting cultivation with a rotation period of 25 to 30 years is universal. » (1964: 133)

In contrast, with their re-using fallow gardens and their intensive methods, the Eipo seemed to focus on infield agriculture. In line with such a focus, Uwok, one of Koch's principal Eipo collaborators, told him:

" If I had a [steel] bush knife, I would clear more secondary garden land. » (1984b: 134)

As regards fencing, Michel (1983a: 49) writes that gardens were fenced off from footpaths so as path and drainage ditch

layer of earth

layer of grass

stones for consolidation

area where soil is scraped off

underlying twigs

staying posts

cross supports

to keep domestic pigs out and Koch's 1985 film about garden making shows the construction of such a fence (1985a, 1987b). The structure consisted of pairs of upright saplings in between which other saplings were laid down and fastened with bark. It looked as if the horizontal saplings with their branches, twigs and leaves were used without further fashioning (Koch, 1987b: 57-58). With two exceptions, the many photographs and drawings of gardens in the team's publications do not show fences. The exceptions are plates 35 and 36 in Michel's Moknerkon monograph (1983a: 49). Plate 35 shows a very roughly constructed contraption of horizontal tree stems and saplings, held together by vertical poles, much as in Koch's 1985a film, and plate 36 a part of a more carefully constructed fence. Apparently, many gardens were not, or not completely, fenced in. The situation is in line with Blum's observation (1979: 12) that feral pigs were virtually absent in the Eipo habitat. Michel (1983a: 150) concludes that fields under sweet potato were in use for a maximum of two and a half years. At the altitude at which the Eipo lived that allowed them three successive plantings. His estimate for the fallow period is about ten years, shorter than reported for many other highlands groups.

The staple crop was sweet potato. Eipo had attuned their cultivation methods to its cultivation by promoting drainage (Michel, 1983a: 59). Following similar reasoning, they considered land cleared of primary forest less suitable for sweet potato cultivation since it retained too much moisture (1983a: 56). Michel (1983a: 87), Koch (1984b: 95) and Plarre (1995: 7) provide different figures for the prominence of sweet potato in the diet, possibly since Michel records the importance of sugar cane. Taro was quantitatively insignificant, but qualitatively far more important than sweet potato. Other crops included sugar cane, banana, pandanus, various vegetables and mushrooms. Plarre (1978) and Röll and Zimmermann (1979: 28) write that the people chewed sugar cane virtually all day long. Nut pandanus grew in Eipo territory, but for oil 
pandanus the people had to rely on trade or exchange (Heeschen, 1990b: 9). Michel related that the people consumed a great variety of vegetables, both cultivated and collected; "they never do without them » (1983a: 71-73; see also Hiepko and Schultze-Motel (1981: 57f) for lists of vegetables, seeds and mushrooms eaten). Also taro leaves were eaten (Plarre, 1978: 3). However, unlike peoples in the western highlands of western New Guinea, the Eipo did not eat sweet potato leaves. Collected vegetables were an important famine food (Michel, 1983a: 72). Most vegetables eaten by the Eipo feature also in diets in the central highlands of Papua New Guinea (Powell, 1976: 127f) and in eastern Indonesia. In Michel's view the vegetables provided relief from the monotony of sweet potato meals in addition to their important nutritional value. Koch (1984b: 85-86) describes two meals that one of his Eipo companions found especially delicious. He ate them in his garden house, hence away from his men's house and in the company of his wife only. The first consisted of a roasted parcel containing a frog wrapped in Rungia klossii and banana leaves ${ }^{20}$. The second meal consisted of mushrooms roasted with Abelmoschus manihot (Heyne does not mention a name in Bahasa Indonesia in his The useful plants of Indonesia; in Minahassa Malay the name is gidi; Tok Pisin: aibika) and Piper sp. leaves (Heyne, 1950: 516f, 1037; Twohig, 1987: 77f). Before eating, he spat pre-masticated salted ash on the food. What in both cases seem to have been the major ingredients: the frog and the mushrooms, were collected items. The authors emphasise the many cultivars for each crop. Plarre (1995: 11) writes that species and cultivars were mixed in gardens, monoculture being almost absent.

Agricultural land was divided into very small parcels, with individuals having scattered holdings (Koch, 1984b: 90). Michel (1983a: 53-55) provides a list of the holdings in a complex of gardens. The large majority was smaller than 40 $\mathrm{m}$. A rationale for the scatter was that people did not lose all or much of their cultivated land when a landslide occurred. In addition, the give and give-in-return that characterised Eipo social life may be a contributing factor. Koch (1984b: 87) reports that Eipo agriculture and collecting yielded enough to cover the caloric need of the people. This statement is probably based on the time period of his research. Eipo told the resear- chers about previous food shortages (EiblEibesfeldt, Schiefenhövel and Heeschen, 1989: 165; Michel, 1983a: 67, 98f), and the severe 1976 earthquakes resulted in a life-threatening loss of harvestable food that was relieved by outside help. Noteworthy is that the researchers found that the Eipo took into account that loss of harvest might occur due to landslides, but that they had not experienced, and hence had not expected, the occurrence of such catastrophic earthquakes (Michel, 1978).

Apart from what Eipo produced to feed themselves, they also produced to feed their pigs and to trade or exchange for goods unavailable in their own domains. As far as the pigs were concerned, their number was very limited. In part that resulted from the taboo that prevented many Eipo from eating pork. In Moknerkon, in 1976, half of the inhabitants were affected in this way (Michel, 1983a: 80). While those to whom the interdiction applied were allowed to own pigs, they were not to care for them (Michel, 1983a: $76 \mathrm{n}$ 97). However, also those who did eat pork, did not own many pigs. In Moknerkon, with 52 inhabitants in June 1976, Michel (1983a: $25,77)$ counted thirteen pigs, both adults and piglets. If, among the Eipo, the introduction of the sweet potato led to intensification of pig husbandry, as noted for many areas in the highlands (for the Ok speakers, Hyndman and Morren, 1990: 21), their pre-Ipomoean pig herds must have been very tiny indeed. After converting to Christianity the Eipo practised fewer pig sacrifices. Their herds became larger and Heeschen (1986b: 206) concludes that feeding them led to food shortages.

Live piglets were prized gifts (Eibl-Eibesfeldt, Schiefenhövel and Heeschen, 1989: 167). They were often already allocated before birth (Michel, 1983a: 79). In Dwyer's terminology (1996) the Eipo were " full male and female breeders » of pigs, meaning that they kept breeding sows and had them inseminated by a domestic boar. Nevertheless, Michel states that pig keeping did not carry prestige (1983a: 79). Methods of pig keeping seemed to promote bonding to their carers, apparently exclusively women (cf. Dwyer and Minnegal, in press; Michel 1983a: 77-78). Hence, while young pigs were transacted as gifts, they were later on kept until slaughter after which pork was gifted. An Eipo was not allowed to eat his or her own pigs. People took

20. I did not find Rungia klossii mentioned in Heyne's encyclopaedic De nuttige planten van Indonesië (The useful plants of Indonesia, Heyne, 1950). W.Vink (pers.comm. 2003) opines that it is not likely to be cultivated in eastern Indonesia because it requires a highlands environment. He noticed it during a stay in the Paniai area, in the far west of the central highlands. The Tok Pisin name is kenkaba (Twohig, 1987: 21). 
pigs along to tether them in areas, especially abandoned gardens, that they could root out. They had to be restricted in their movements, in the absence of completely fenced-in gardens. On very steep slopes they were carried along (1983a: 76). Pigs spent the nights in family houses either with the human inmates on the same floor or in sties underneath (1983a: 84-85). At home, they were fed sub-standard sweet potato.

Another reason why the Eipo produced sweet potato and other foods beyond their dietary requirements was that they used the tubers as an item of trade or exchange. Several of the materials that they needed for their tools were not obtainable at all, or not in the quality desired, from their habitat so they had to deal with others. Michel (1983a: 107-108) lists the goods that Eipo obtained from outside, including those for which they were intermediaries. Goods obtained included stones for knives and adzes, rattan for belts, cassowary feathers and daggers, most wealth objects and objects of finery. Apart from sweet potato, Eipo offered banana, taro, leafy vegetables and a non-food item, looped bags. As mentioned, Heeschen writes (1990b: 9) that in order to get the items required Eipo had to have « friends » beyond their valley. In another publication Eibl-Eibesfeldt, Schiefenhövel and Heeschen (1989: 168f) argue that also trade of utilitarian goods took the form of gifts. Trading partnerships were retained over the generations (ibidem). In contrast to the great value that the Eipo accorded to the inalienable, sacred objects held in the men's houses, accumulation of alienable wealth items - if only to give them away - seems to have been of minor importance to them. Personal finery counted as wealth and specimens were among the objects exchanged between bride-givers and bride-takers and in compensation payments. Headbands set with nassa shells were the most treasured, and apparently scarce, items of finery (Simon and Schiefenhövel, 1983b) ${ }^{21}$. Eibl-Eibesfeldt, Schiefenhövel and Heeschen (1989: 149) write that one nassa shell headband was worth one leg of pork, thus highlighting the value accorded to pigs. Gardner's (1990: 22) remark about the Ok-speaking Mianmin, that items were alienated or acquired for their use-value rather than their exchange-value, was applicable to the Eipo, under the proviso, however, that donees in their turn often handed on usables such as gifted foods or tobacco (Eibl-Eibesfeldt, Schiefenhövel and Heeschen, 1989: 150, 168). A film by Simon and Helfrich (1987) shows a young man wearing a nassa shell headband before he gives it away (Ohnemus, 1989), but it has remained unclear to me whether such items of finery in the course of time became inalienables, at least for the lifetime of its owner.

Eipo were apprehensive about the outcome of their agricultural activities. With their ancestor cult they attempted to safeguard success. Making gardens included a range of rituals and acts of magic: to enhance fertility, to prevent landslides or to stop their further occurrence, to ward off spirits, to prevents thefts and so on (Michel, 1983a: 60f).

At the altitude at which the Eipo lived, sweet potato formed a significant addition to their range of crops. Its introduction may have enabled them to move to their 1970's habitat. It had ample land that the people considered suitable for sweet potato cultivation, namely steep slopes with their drier soils (Michel, 1983a: 50). In contrast, the inhabitants of Moknerkon had little land particularly suited for taro cultivation. Nevertheless, the introduction of sweet potato is not discussed in Eipo oral traditions. Michel (1983a: 61) writes that the people regarded sugar cane, bace (Saccharum edule; Hiepko and Schultze-Motel, 1981: 61), towar (Calamus sp.; ibidem: 64) and banana as the cultigens of primordial times, while taro is not mentioned. Sweet potato was a domestic crop. Mothers gave their newly born infants pre-masticated sweet potato -and sugar cane- to eat (Schiefenhövel, 1988a: 60). Taro was ritually and ceremonially a more important crop, a development that must have taken place after sweet potato had succeeded it as the staple crop. Taro was, in the 1970's, almost completely the concern of men. Women were allowed to plant and to eat taro, but not to look after and to harvest it (Michel, 1983a: 147). In the same paragraph, Michel suggests an association between taro and the ancestor cult; Eipo called their ancestor skulls « taro heads »-that is to say that part of a taro plant that is replanted and produces new corms- and held them responsible for their harvests.

\section{Social Organisation}

\section{Initiation}

Above I mentioned agnatic descent as the main principle underlying clan membership. Initiation rituals, especially the kwit rituals, formed

21. Koch made an inventory of the wealth items owned by Malingdam men in October 1974. Of the 54 men only two owned a nassa shell headband (1978a). 
another dimension of social organisation. In his 1990b compilation of texts, Ninye Bún, Heeschen discusses only these rituals (1990b: 110f), but in the monograph that he wrote with EiblEibesfeldt and W. Schiefenhövel, two further initiations are discussed (1989: 186f): donning the first penis gourd and plaiting in a hair appendage (similarly Koch, 1984b: 20). But the descriptions intimate that kwit rituals were the only rites de passage that initiated a group of boys. They were of larger scale than the other two and, finally, were the only ones that were part of the ancestor cult. They were held at intervals of about five to ten years. The different authors present slightly different figures. They did not observe the ritual since it did not take place during their stay and was discontinued with conversion to Christianity. Hence they had to reconstruct the proceedings and their significance from oral statements.

The proceedings lasted about two months. The initiands were separated from their mothers and, after a night in the men's house, brought over to a house away from the villages. In the men's house they had to spend the night standing up, but the youngest boys who were unable to do so were put in carrier bags that were hung from the ceiling, thus signifying the motherly sphere in which they were still enveloped. They spent one month in the isolated house after which the central ceremony took place: an appeal to the clan ancestors near a central pole. A plate with a meal of taro and bace 22 was taken from a cover of leaves. Pole and plate signified the presence of the ancestors. The initiands were anointed with pig's fat, like the ancestral remains kept in the men's houses, and received strips of fat, especially belly fat, so they themselves could later repeat the procedure (Helfrich, 1978b; Koch, 1984b: 131; Eibl-Eibesfeldt, Schiefenhövel and Heeschen, 1989: 136-137). At this time they were told the secret, sacred names. Knowledge of these names set them apart from those who were not initiated. After another month the initiands were brought back to the village where they were led to the men's house over the bodies of the women. The initiation ended with the newly initiated offering small presents to the women. Heeschen argues that they thus showed their growing independence from women to whom, henceforth, they would give larger and larger presents (1990b: 111).

According to Heeschen, kwit was designed to further the economic well-being of the initiands. It separated them from the women's domain and introduced them to the men's house community. It happened when some of the boys were still very young. Heeschen writes that they were three to ten years ${ }^{23}$. Some were not trained so the $k$ wit house was filled by the stench of urine and faeces (1990b: 116). Boys from different clans and from different valleys were initiated during a single ritual. Eipo distinguished groups of men initiated together with specific names. Several of these groups had been initiated in a ceremony that had taken place outside the Eipomek valley. Hence kwit linked men with others outside their clans. It also introduced them into a sphere of secrecy and taboos that set them further apart from especially women.

After kwit, boys were still ritually inferior to adult men. In the men's house their place was near the entrance, away from the sacred relics that were usually situated in the back of the house (Michel, 1983a: 42; Koch, 1984b: 20). And given that boys were so young when they were initiated, learning secret names was likely to be a continuing process. The names had to do with the creation of the present world. They included personal names (Koch, 1984b: 126), and those of ancestors, animals and cultivars (EiblEibesfeldt, Schiefenhövel and Heeschen, 1989: 188). In addition to the sacred objects held in men's houses, these names constituted, for the Eipo, another category of secrets. The man who was the first to tell Heeschen about the creation of things told him secret names, for half an hour (1990b: 19). Hence knowing names seems to have been " ritual capital », a phenomenon that is reminiscent of Sepik ways of life. However, the team's published findings do not make it clear whether or not Eipo men used them also as political capital (cf. Harrison, 1990: 19). Those not initiated might know about the events or the other entities that the names referred to. For instance, Heeschen writes (1990b: 19; 1998a: 26) that a young girl might well know about the primordial pig, but that she was not to know its secret name. Nevertheless, my impression is that women did not know the course of the kwit ritual and were not supposed to know. When they chanced upon part of the proceedings, the men fobbed them off (Heeschen, 1990b: 111). Hence, such ritual proceedings were yet another category of secrets. Moreover, given that Heeschen (1990b: 11) writes that Eipo did not tell but

22. Saccharum edule (Hiepko and Schultze-Motel, 1981: 61); Heyne does not list a Bahasa Indonesian name; for Manado Malay he lists sajor lilin (1950: 160); the Tok Pisin name is (lowland) pitpit (Twohig, 1987: 78). As mentioned, Eipo regarded bace to be one of their first crops (Michel, 1983a: 61).

23. Helfrich (1978c): four to eight years; Eibl-Eibesfeldt, Schiefenhövel and Heeschen (1989: 11): five to sixteen years. 
instead acted out their knowledge in ritual; ignorance of ritual is simultaneously lack of knowledge.

According to Koch (1984b: 20), the second initiation during which boys were given their first penis gourds to wear, was a «slight event » (ein schlichter Vorgang). His description suggests that it did not require the co-operation of a wider group of men. About the third initiation, plaiting the appendage into a young man's hair, Eibl-Eibesfeldt, Schiefenhövel and Heeschen (1989: 188) write that it took place in a « small, solemn ceremony ». They observed it once and on that occasion two young men were given the appendage to wear. It had a phallic shape (see also Koch, 1984b: 31) and according to the three authors (ibidem) it had to remind the wearers that they were now " on the one hand attired with symbols of prosperous growth, like the earth was attired with food plants, and on the other should realise that they owed their mother's brother who had presented them with numerous gifts since the kwit initiation ").

That boys went through the first initiation at an early age is in line with Koch's observation that children looked « oldish ». They appeared to him to be « adults in miniature » (1984b: 126; for visual examples see films by Simon and Schiefenhövel (1983a) and Koch (1985d)). They were also knowledgeable. Plarre, himself a plant breeder, writes that young teenagers gave him the best information about plant varieties. One of them was able to correct him when identifying sweet potato cultivars (1995: 3). At an early age, from five years onwards, their fathers allocated their children their own small garden plots (Michel, 1983a: 50)

\section{Marriage}

Rather surprisingly, the team's publications do not include a full discussion of marriage and affinity. The data have to be pulled together from incidental references. Eibl-Eibesfeldt, Schiefenhövel and Heeschen are the only authors describing a wedding (1989: 183f). They report how a young woman took up residence in her husband's village. Thus, they write, she became married. Accordingly the proceedings seemed extraordinarily informal and small-scale. They add that a wedding did not occasion the payment of a costly bride price, but rather mutual prestations beween bride-takers and bride-givers over a lengthy period of time. In the example they give, the family of the bride had presented the groom's family, in anticipation of the wedding, with two adze blades, two bows, two large carrier bags, and a forehead ornament made of cassowary feathers. The groom was to reciprocate with white glass beads, a wealth item introduced by the German researchers. Eibl-Eibesfeldt, Schiefenhövel and Heeschen do not make it clear whether these prestations amounted to a set series or were, instead, ad hoc arrangements. Heeschen writes elsewhere that the Eipo practised the exchange of brides. He mentions this while discussing the creative work of the ancestors (1994a: 169) and does not elaborate. One of the marriage prestations was the provision of labour, given that Michel (1983a: 38, 46) and Heeschen (1984a: 121) write that the groom sometimes helped his prospective father-in-law, especially shortly after the wedding when the couple still resided "bilocally» (Helfrich, 1978c). And another is the valuable present, for instance a nassa shell forehead band, that an initiate might give his mother's brother in exchange for the support he had given his sister's son in the course of the initiation. Since marriages, and the possibility of a forthcoming marriage, linked people from different neighbourhoods and from different valleys, it widened the circle of relatives and exchange partners. Moreover, marriages brought about lengthy associations between the families of husband and wife.

After the bilocal phase, residence after marriage was mostly virilocal. Brides came also from other valleys, to the extent that the inhabitants of Eipo villages spoke a number of Mek dialects. Uxorilocal residence did occur, but carried disadvantages. This was because it made the couple dependent on others for garden land. Schiefenhövel presents demographic data about the inhabitants of Mungguna, Dingerkon and Malingdam (see map 2), as per August 1975 (1988a: 72f; see table 2). Most people lived then monogamously, with $12 \%$ of the men having more than one wife, mostly two, in one case three. In the villages it seems to have been rare that a husband spent time with his wife in their family house. Husband and wife did work together in their gardens, and might stay overnight in their garden house (Koch, 1984b: 54; Michel, 1983a: 29). That happened when they wanted to be away from the villages, liking each other's company, but another reason was that the husband might want to prevent an abduction or elopement.

\section{Security Circle}

For the Eipo, the village is "the nucleus, it is the social, economic and political center » (Michel, 1990: 11). In addition, initiation 
provided people with allies beyond the village. And, they needed trading partners to acquire the necessities that they could not obtain locally. To characterise Eipo social organisation, Heeschen uses Lawrence's concept "security circle " (1984a: 129f), even though Lawrence (1984: 5, and passim) coined it to help account for social cohesion among people without descent groups. I assume that affines were often included in people's security circles. The data are not comprehensive enough, however, to assess this. Important in maintaining social relations was the pervasive gifting. Gifts are « regular and numerous » between the members of nuclear families, of " local lineages, and co-residents of men's and women's houses» (Michel, 1983a: 109). And Heeschen writes:

«In the afternoon the Eipo arrive with their carrier bags full in the villages, they exchange part of the daily harvest with neighbours and friends [...]. When one of us [the members of the research team] sat down in a men's house, he was given tobacco, sweet potato and so on [...]. An Eipo is ashamed to eat without sharing. » (Heeschen, 1984a: 115)

In the same paper, Heeschen contrasts Eipo with the Yalenang among whom people attempted to avoid sharing, and apparently often succeeded in doing so. Eipo told him that they preferred living in sizeable villages with their opportunities for interaction and gifting. In contrast, the Yalenang preferred to withdraw to their garden houses.

In addition to the day-to-day informal sharing, exchanges occurred at the group level. However, they were carefully planned. Inhabitants of a village took stock of their resources, especially pigs, and arranged with the inhabitants of another village to stage a mutual exchange feast in the near future. Favoured exchange partners were villages where the same language was spoken, in the Eipomek valley, in Tanime, or across the main divide, in Larye (see map 3). Festivities were indeed prominent. Preparations included dance and song rehearsals. The occasion gave rise to oratory, an important way for men to distinguish themselves. Although the prestations were made at a time that the two groups, hosts and guests, celebrated together, they were at the same time transactions between individual exchange partners, often long-term ones.

«What presents itself as a community, turns out to be a valley-wide net of individual relationships that operates as a unit. » (Eibl-Eibesfeldt, Schiefenhövel and Heeschen, 1989: 151)

Elsewhere, Heeschen discusses the proceedings under the heading "Dance and Feast», mot (1990b: 224f) and writes that they were " the highlights in an Eipo's life » (1994a: 121; 1998a: 21), revitalising social life ${ }^{24}$. The feast could take place only when the resources of both villages were about equal. Eipo apparently did not approve of shaming their exchange partners by giving them a gift that the partners found hard to match. Rivalry was not openly expressed. In M. Strathern's wording, the Eipo were among those Melanesians whose exchanges « rest on principles of equivalence » (1991: 1). People had to rely primarily on production, rather than finance (A. Strathern, 1969) to step up their contributions (Michel, 1983a: 151). Those who succeeded contributing more than others did earn prestige. These were exchanges of like for like, another feature that makes the Eipo way of life resemble that of the "Great Men societies ", first identified by Godelier (1982). I return to this matter when discussing political organisation.

Although they professed liberality, Eipo were uneasy about giving. They were anxious to receive just as much as they gave away. Michel notes that several married couples regularly came to blows over the distribution of food (1983a: 109). Using Sahlins'terminology, Heeschen concludes that ideologically Eipo were committed to general reciprocity, but that in fact they practised balanced reciprocity (1984a: 130). Eibl-Eibesfeldt, Schiefenhövel and Heeschen note the same phenomenon, but conclude with the observation that gifting is not merely the result of calculation:

« the pleasure to be able to give somebody else a present that he likes or can put to good use, can often be read from their faces. » $(1989: 150,168)$

While the immediate exchanges described in the above paragraph were festive occasions resulting from ample food supplies, there were also delayed exchanges, in times of shortage. The researchers estimate that in early 1976 the inhabitants of Inlom who were in need received 1000 kilograms of food from neighbours. The neighbours also performed fertility magic (Schiefenhövel, 1988a: 72; Eibl-Eibesfeldt, Schiefenhövel and Heeschen, 1989: 165). Here too, there is the element of calculation since people expected a return gift, or attempted to secure one when they

24. Simon and Schiefenhövel show in two films (1989g, 1989h) parts of an exchange feast held in Munggona in 1976 Heeschen (pers. comm. 2002) told me that a reciprocal feast was held two years later. 
themselves would be in need (Michel, 1978). With the risk of landslides being permanent, such local occurrences of food shortage were an equally permanent threat.

\section{Infanticide}

In Schiefenhövel's view Eipo concern about the adequacy of their food supplies resulted in infanticide (Schiefenhövel, 1988). He notes the absence of contraceptive measures and of deliberate abortion (1988: 83). $\mathrm{He}$ and his wife observed one case of infanticide and another one in which the mother contemplated, but rejected it. Infanticide took place immediately after birth. The mother wrapped the child plus the afterbirth in leaves and ferns and abandoned it. Grete and Wulf Schiefenhövel documented its wider occurrence by means of the genealogical method and they also noticed that the 1976 earthquakes that wiped out much garden land were followed by a number of infanticides (Michel, 1978; G. and W. Schiefenhövel, 1978).

The results of their, and Koch's, genealogical inquiries enabled them to survey Eipo demography. It appears that mothers left more girls than boys to die. Accordingly, among the younger generation males outnumbered females. This imbalance, however, shifted over the course of the years and women started outnumbering men in the later phase of life. The population figures collected showed a low number of women in the age category of 30 to 44 years. Schiefenhövel (1988: 73) speculatively adduces several reasons for its occurrence, one of them being a larger incidence of female infanticide due to a famine. Because there were more young men than young women, many men married late, or married widows who were considerably older than they were themselves. Both Schiefenhövel (1988: 80) and Koch (1984b: 17, 125) report polyandry, although it remains unclear whether the partners in these unions were duly married. At the time, about $5 \%$ of the men remained bachelors throughout their life. Sexual misdemeanours, such as adulterous affairs and elopements of women, occurred frequently and were an important reason for fights within neighbourhoods (Schiefenhövel, 1988: 79; 2003: 108).

Schiefenhövel opines that the Eipo consciously endeavoured to keep the population stable. He compares the population composition for the several Eipo neighbourhoods studied and concludes that Malingdam, the most southerly one, closest to the central divide and at the highest altitude, was still in a phase of expansion with the proportion of young persons, and also of young girls (1988a: 76), there being larger than in the other neighbourhoods. The population of Malingdam contained a number of migrants, including people who had come from valleys south of the main divide. He also points to the awareness among Eipo that unfavourable harvests would result in food shortages (1988a: 67 ), while their current techniques would not easily allow larger harvests (1988a: 72). That Eipo practised more infanticide after the earthquakes (Michel 1983a: 149; Michel, with Koch and Schiefenhövel 1989: 206), hence at a time that it was unclear whether future food supplies would be adequate, supports Schiefenhövel's argument. That the Eipo practised infanticide rather than abortion or contraception is another supporting argument, since the latter two strategies would not allow skewing the birth figures to favour boys (Smith and Eng, 1977; Lavely and Bin Wong 1998: 734f).

Nevertheless, it should be taken into account that also the neighbouring Ketengban and the Ngalum, farther east, and the Mek speakers in the Sela valley, to the southwest across the central divide, practised infanticide (Godschalk, 1993: 58-59, 195f). About the Ketengban, Anne Sims writes:

« One of the primary reasons for infanticide seems to have been a wife's desire to take revenge on her husband ... [because] he was not providing enough materially for her [...] [or because] he treated her harshly [...] [or because] the bride price had not been large enough. She might also try to punish her husband out of jealousy over a second wife. » (Sims and Sims, 1992: 106)

Hylkema (1974: 168f) writes about the Ngalum in Apmisibil that the number of infanticides was hard to ascertain since women spent much time in the women's houses by themselves. $\mathrm{He}$ discusses four cases. In the first, the woman was angry with her husband; in the second, the same woman was said to have persuaded a mother to kill her child. In the third, a woman had given birth to a sixth child and was said to have been apprehensive about adverse reactions from other villagers. In the fourth, a young man had picked a live, abandoned infant from the privy of the women's house. He persuaded the mother to accept the child and later on people came to recognise him as its father. Elsewhere Hylkema (1974: 403) observes that the Apmisibil Ngalum thought their valley to be underpopulated. Hence among them infanticide was demographically undesirable (for the Sela, see Godschalk, 1993: 58f). These examples from the Ketengban, the Ngalum and the Sela make it clear that the 
Eipo shared the practise of infanticide with other ethnic groups in the eastern highlands of western New Guinea. That the Eipo did so as one means to prevent population pressure, as argued by Schiefenhövel, would mean that with this purpose they differed from these other groups.

\section{Gender}

Under this heading, I discuss the Eipo notions concerning the differences between men and women and the associated socio-cultural practices. Several of the team's researchers touch on this topic in the course of their writings, but few of their papers, or of sections of larger essays, specifically deal with it. Heeschen wrote an unpublished paper for discussion during the 1990 Seewiesen conference. More recently, Schiefenhövel (2001) devoted a paper to the topic in a festschrift for Eibl-Eibesfeldt. This paper generalises, while Heeschen's paper focuses on the Eipo. I am drawn to the latter paper, although tantalisingly brief, due to the ambiguity that Heeschen perceives in the relations between Eipo men and women.

Reviewing the various elements of the Eipo way of life, touched upon in other parts of this essay, Heeschen first points to the primacy of men. While men built the first men's houses, establishing the geographical and ritual center of their habitat, women were absent, dancing in the periphery. Ever since that primeval time men's houses have remained the domain of men, out of bounds to women. In daily life, Eipo men feared and avoided coming into contact with vaginal secretions (Heeschen, 1990: 1; Schiefenhövel, 2001: 276), so menstruating and birth-giving women had to reside at the periphery of the settlements ${ }^{25}$. Echoing an argument developed long ago by British social anthropologists (for example: Gluckman, 1956: ch. 3), Heeschen argues that also in the era in which he and his colleagues did fieldwork women came in from the periphery: they married in, leaving their natal settlements located on their own clan land. More adult women than men committed suicide (Schiefenhövel, 1988a: 83) which points to a less secure life situation for women. And more women than men were killed after accusations of sorcery or witchcraft (Schiefenhövel, 1989a: 183). Hunting grounds, high up the mountains, used by men and close to the abode of their ancestral spirits, were taboo to women. In line with what happens in many Melanesian communities, initiation moved boys away from their mothers and closer to their fathers. However, they were also instructed to regard the spirit woman as their ancestress. In addition, the Eipo associated the spirit woman with the mountain that had given birth to the ancestor (1990: 4). Eipo regarded her as promoting crop fertility. Accordingly, initiation did not set boys against the female forces influencing their lives.

J. Weiner reports that among the Foi, living on the southern fringes of the highlands of Papua New Guinea, « in mundane subsistence activities, men are the initiators [...]. Women, by contrast, maintain the initial efforts of men»(1991: 5-6, his emphasis). Although the German researchers do not state this explicitly, the subordination of Eipo women might be expressed similarly. But Weiner adds that with respect to poetry the opposite is the case (ibidem). Again, the situation has parallels among the Eipo where women were the composers of songs, even though, as Heeschen states, « the Eipo [men and women] are a singing people » (1989b: 186). Composing songs was, it seems, the female counterpart of male oratory. Heeschen's male Eipo collaborators told him that women composed them when they had love affairs. They claimed ignorance of the meaning of the texts (1990b: 305). Schiefenhövel writes that women sang during labour (1982a: 839) ${ }^{26}$. With their songs, women influenced the course of change of the Eipo language (Heeschen, 1998a: 26). Moreover, Heeschen mentions that women may ridicule men in their songs (1990: 2). Women did so, for instance, when some men opined that the peanut, a cultigen that the Eipo had accepted after its introduction by the German team, was not to be eaten by women (ibidem: 15).

To underscore his conclusions about the ambiguity in gender relations, Heeschen notes the close co-operation between husband and wife, as also documented by Koch (1984b: 102f) in his accounts of garden work. The films produced by the team show husband and wife together at work clearing grass regrowth on land for a new garden (Walter, 1982). Moreover, and more fundamentally, Heeschen (1990) detects, as regards the men, an element of shame in their behaviour towards women, without, however providing

25. But men - and not only shaman - were prepared to enter the women's house, while a woman was in labour (Schiefenhövel, 1984e: 4; 1988a: 103-4).

26. «Sometimes they express their pain in song-like patterns which in their descending melody resemble the cross-cultural rather uniform mourning songs. » 
more than one example: men leading dancing groups experienced shame because women saw them performing. He does not explain why men experienced such shame. But since he surmises that Eipo men thought that they had usurped female fertilising powers, this infringement might be the, or one, reason. As far as the women were concerned, when taking part in rites that seemed to express gender antagonism and that relegated, or seemed to relegate, them to a secondary position, for instance in the kwit initiation ceremonies, they did so willingly.

Gender relations have been discussed among anthropologists almost from the beginning of research among highlanders. They noted the kin, residential and ritual features of the separation between men and women. J. Weiner (1988: 42f) approvingly quotes A. Strathern's statement (1970: 378):

« if we stress that initiation rites dramatize male solidarity, male opposition to females, and so on, we are faced with the problem of assessing the strength of these values in different Highland societies. "

Weiner proceeds to argue that among the Foi the opposition between men and women has to do with « men's notions of menstrual blood and female reproductive capacity and the obligation of Foi men to channel, control and transform them » (1988: 43). Because such notions concern procreation and the continued existence of the group, I agree that they are likely to be more fundamental than the gender opposition expressed in residential and ritual features. Accordingly, the latter opposition equally likely derives from notions about sex and reproduction. But notions of menstrual blood and female reproductive capacity also are liable to be variable, so we are still faced with the problem of assessing their strength. Hence, it is noteworthy that men, especially but not exclusively healers, were on occasion present in or near the women's house while women were in labour (e.g. Schiefenhövel, 1984e; 1988: 28, 32, 88). Since that suggests that they were prepared to risk contamination by vaginal excretions, the opposition between Eipo men and women may have been moderate. It is also noteworthy that Eipo women seemed to have an important say in their choice of a marriage partner. Eibl-Eibesfeldt, Schiefenhövel and Heeschen (1989: 183f) report that young women sought out men which in numerous cases led to love affairs and marriages. They write about a newly married woman that she left her husband's village, because she did not like it there, and returned to her home village. Divorce occurred regularly (ibidem).

\section{Hostilities}

Schiefenhövel (1984c; 2001a: 178f) describes the Eipo as martial, with a death toll due to hostilities slightly lower than among other highland ethnic groups. The people distinguished between mal, war against traditional enemies, and abala, armed conflicts within a community, most usually a village or a neighbourhood (Heeschen, 1990b: 260f). The researchers observed and recorded instances of mal and of abala. Mal was a group affair, abala sometimes, but not always. Eipo disapproved of killings in abala (Schiefenhövel, 2001a: 179) and impressed upon the younger generation to avoid them. Mal, war, they saw as part of the normal state of affairs. War was ongoing and " continues in a cycle of defeat, retaliation, fear and triumph » (Heeschen, 1990b: 260f). It did not aim at land conquest, but at retaliation and often entailed destruction of the enemy's assets. If an enemy's corpse was secured, it was eaten, however only in case his opponents were " sufficiently enraged to justify this ultimate humiliation » (ibidem: 261). Unlike allies, killed enemies were not compensated (Schiefenhövel, pers. comm. 2002). Nevertheless, wars were not always permanent. Heeschen's texts contain a call for peace among warring parties (1990b: 302f). Unfortunately he does not provide the context in which this occurred.

In the mid-1970's, the Eipo's main opponents in $\mathrm{mal}$ were the inhabitants of the valley of the $\mathrm{Fa}$, a tributary of the Eipomek river (see map 2). In the decades before the arrival of the research team, the latter had defeated the inhabitants of the Eipo village Walubok and set fire to it. In Michel's estimation this happened around 1930 (1983a: 19f). Its inhabitants had fled further south and, after another fight, a number had, around 1968, built Moknerkon, where Michel carried out his field research. In the course of the team's research, another episode in the enmity between the Eipo and the Fa was fought (Koch, 1984b: 128f). It started with the surprise killing of an Eipo man who returned from a trading or exchange journey. Rumour had it that the Fa had eaten the corpse. That same day a group of Eipo started attacking the Fa. While 19 days later it became known that one of them had died after he had been earlier wounded, this did not stop the Eipo from further attacks. Koch had to terminate his field research shortly afterwards, when the Eipo were still expecting further fighting (1984b: 129-30). Another indication of the shifts in enmity in the area is that, in Heeschen's view (1990b: 261), relations between 
the Eipo and the Fa were at the time improving, mainly on account of increasing social links among them, including those of marriage and affinity.

The team members also witnessed a number of instances of abala, internal fights (Michel, 1983a: 99f; Koch, 1984b: 127f; Eibl-Eibesfeldt, Schiefenhövel and Heeschen, 1989: 200f). What is striking in their descriptions is how people used violence in moderation. In Koch's (1984b: 127) words: « Typical was the inhibition to inflict too much damage on one's opponent $»$. In one instance Michel (1983a: 100) recorded how an exchange of abuse was followed by shooting arrows, aimed however at houses rather than people. Although the opponents answered by shooting at people, they gave in after some of them had been wounded. The researchers observed another case of violence after a young man, named Ebna, had suddenly and unexpectedly died. His elder brother, an ascendant man, mourned Ebna publicly, for months. He attributed the death to sorcery and shot at the suspect, an Eipo living in another village, wounding him. The wounded man died some time later, probably due to his wound. Only then the elder brother gave Ebna's corpse a second disposal (EiblEibesfeldt, Schiefenhövel and Heeschen, 1989: 196f).

Heeschen (1990b: 260) writes that abala, internal fights, might have taken more lives than mal, wars, whereas Schiefenhövel's calculations (2001a: 177-178) suggest roughly similar numbers. He adds that abala due to sexual offences accounted for the majority of intra- group killings (2003: 104). Yet, as mentioned, Eipo regretted deaths in abala. Both parties to the conflict did so. However, they rejoiced in a killing in mal. Given that men were apparently free to take to arms in reaction to perceived wrongdoings, a great deal of violence was likely to occur. I take it that, in the case of Ebna's death, people realised that his elder brother was going to take revenge. But apparently they did not attempt to restrain him. If, under such conditions, people nevertheless felt restraint in using violence, this attests to the strength of the community relations among the Eipo.

Although Heeschen, in his annotated collection of tales (1990b), includes Godelier's 1982 book La Production des Grands Hommes in his bibliography, he does not analyse Eipo sociopolitical organisation by means of the concepts developed in that book and in the ensuing discussions. Yet it seems useful to me to do so since it relates Eipo sociality, or « social logic », to the modalities of social organisation reported for the central highlands of eastern New Guinea, the area Godelier and, following him, Lemonnier are concerned with. Prominent men among the Eipo were Leaders, in the meaning that Lemonnier (1990: 125; 1991: 19) has given this term. Eipo Leaders were good fighters, but were also the men who organised festivities and were the orators on these occasions 1990: 123f). I refer especially to what was apparently the major form of institutionalised exchange of wealth among the Eipo: the village feasts during which villagers gave food, including pork, to their guests, from another village, in anticipation of later returns. In everyday life, the role of Leaders seems to have been minimal, also in quarrels and escalating fights. In the above, I pointed to several features of the Eipo way of life that they had in common with the Great Man societies as conceptualised by Godelier. I mention the small scale of their social and political groups. Secondly, marriages were contracted by exchanging brides, although not necessarily sisters and although it sometimes took more than one generation before the exchange was completed. Furthermore, most often exchanged were consumables, especially food and services rather than durable wealth items. Finally, people killed in war were not compensated for by the party of the killers but revenged by their opponents (Schiefenhövel, pers. comm. 2002). However, the warrior element in Eipo leadership, and the place of warfare in their way of life, was less prominent than can be gauged from Godelier's model, despite Michel's remark (1983a: 151) that renown was closely, and positively, associated with physical strength. Michel explicitly denies that Eipo leaders were Big Men (1983a: 149). Moreover, unlike Godelier's Great Men, who are often specialists in fields such as warfare, magic, hunting and so on (Godelier, 1990: 11f), Eipo Leaders combined at least a number of the qualities that marked them out (Heeschen, 1998a: 22; 1990b: 188). Considering the above, I have opted for Lemonnier's term « Leaders ».

\section{The Eipo and their Neighbours}

The title of this section derives from «The Mek and their Neighbours », the name given to the conference held in Seewiesen that formally ended the Eipo research project. In this section, I present data on other Mek speakers and the relations between them and the Eipo. Mek speakers live in a contiguous region, in between the Yali, their westerly neighbours, who speak a language belonging to the Dani family, and the 
speakers of the Ok languages (see map 3). The region straddles the central divide.

The ancestral wanderings that Mek myths of origin related were geographically precise (Heeschen, 1994a: 168), although many Eipo had not themselves seen the areas concerned. Many of the mountains that Eipo see as the origin of their ancestors were in easterly parts of the central divide, close to the area nowadays inhabited by Ok speakers. Hence these mountains were not within view of their descendants. The first sections of the wandering routes away from the mountains to the current habitat were situated along the southern edge of the divide, while at the start of the team's fieldwork -and up until now- most Mek speakers lived north of the divide. On the basis of linguistic differentiation, Heeschen subdivides the Mek region into three and concludes (1994a: 176; 1998a: 20f) that the Mek speakers have migrated away from the Eipo - Larye - Tanime area (see map 3). For in this area linguistic differences are greatest. He sees Nalca, west of the Eipomek valley (see map 3), as a secondary centre of dispersal. In his view, the ancestors of the Yalenang had moved away from the Eipo - Larye - Tanime area about 400 to 500 BP, moving first west and, subsequently, spreading from Nalca west, north and south. In his estimation settlement of the Yale valley by ancestors of the contemporary Mek speakers had started about 250 years BP (1994a; 181). Because of his work among Yalenang, he was able to compare their way of life with that of the Eipo (1984a, 1994a, 1998a). He does not have comparable data on Mek migrations to the eastern area. In his comparative publications he characterises the way of life of the Yalenang as one of migrants who had not established stable, long-term relations with their neighbours (1984a: 128). Among other matters, he points to their reluctance to share, and the absence of favourable relationships between bride-givers and bride-takers, and contrasts these features with what obtained among the Eipo.

Inter-valley social contacts in the central area were many: intermarriage, exchange feasting, trade and exchange, and initiations that at times included youngsters from more than one valley (cf. Michel, 1983a: 43). Women from other valleys who had married Eipo men continued to use their local dialects (Heeschen, 1998a: 20), so in many Eipo villages several dialects were spoken. Trade relations of the Eipo were largely with downstream villages, although apparently rarely with those in or close to the lowlands, and with those in neighbouring valleys, both to the west and east and across the divide (Michel, 1983a: 107f). In line with the Eipo's preference for a cooler climate, most of their trading partners lived at similar, high altitudes (Michel, 1983a: 14). Michel reports (1983a: 110) trading contacts with Batamur, about 40 kilometres north of the upper Eipo (1983a: 40). He dates the first at about 1960. The trip took the Eipo traders ten days, one way. There was little follow-up, except for a reciprocal visit. Later five Eipo, among them one woman, undertook another expedition. The main trade routes ran north and south of the upper Eipomek valley, at lower altitudes where the terrain is less dissected. Moreover, the area had few specific trade goods to offer (Michel, 1990: 3). Because of the prevalence of step trade, however, people in the upper Eipo had access to goods from further afield than the areas where their immediate trade partners lived. Trading partnerships were inheritable and hence might be long-lived (Eibl-Eibesfeldt, Schiefenhövel and Heeschen, 1989: 168).

Heeschen's interest in the Eipo past led him to prehistorical speculations. He notes (1994a) that both the Yali, as reported by Zöllner (1977: 46, 447; 1988: 18, 172), and some Ok speakers, as reported by Brumbaugh (1990a: 62, 72, 74-5), held that their area had earlier been populated by other, different people. Heeschen also notes that the Eipo and the Yalenang had clan-specific myths of origin, with specific totems and specific routes followed by clan ancestors away from where they emerged to where they settled down. In contrast, many of the Ok peoples and the Yali had " generalised myths » of origin according to which all of them had come into being by the creative activity of the same entity or entities. In the case of these Ok peoples, a woman, Afek, had been the creator (Brumbaugh, 1990a: 66). And in the case of the eastern Yali it had been a couple that created humans by scattering parts of a primeval pig that they had killed. According to the western Yali, the primeval couple were a mother and her son. After the son had killed his mother, her corpse had transformed into a pig and humans had originated from the parts of that pig (Zöllner, 1977: 57f; 1988: 19f). Analogously, while the Eipo held that each of their clan ancestors created a part of their habitat, the Ok peoples ascribed it to Afek who trekked through the territories of the present-day Ok peoples, first from east to west, subsequently turning back to settle at Telefol (Brumbaugh, 1990a: 62-3; map in Michel, 1990: 14). The Yali believed that their habitat was formed after two men had felled a giant tree, Yeli. Afterwards Yeli trekked from east to west transforming the land and 
making it suitable for human habitation. However, Yali did not believe that Yeli returned: he went as far as the lower Grand Valley where he turned into a mountain (Zöllner, 1977: 57f; 1988: $18-9)^{27}$

Not all Mek speakers, however, adhered to the clan-specific origin myths that the Eipo held on to. The Ketengban, the easternmost Mek speakers, posited that a single deity had created « the physical universe, including humans and animals ». That notion applied foremost to the area that Ketengban saw as their heartland, namely the Bime valley in the western part of their habitat (Sims and Sims 1992: 32). As I mentioned above (see p. 19), they regarded that habitat as shaped by a dying primeval pig that, after having been shot, bounded through the air in a great circular path throughout Ketengban territory, stopping briefly in numerous places. Each place where it landed became a clan centre, a key initiation house, or another important ritual house (Sims and Sims, 1982: 35). This myth unified some seventeen villages spread over a number of valleys, from Bime, east of the Eipo valley, farther eastwards to the eastern border of the Mek territories (see map 3).

In the Afek myth, Afek chases «prior occupants » (Brumbaugh, 1990a: 62) during her peregrinations and Heeschen opines that this passage refers to a shift in accounts about the past. The "accounts of wanderings [of Mek speakers], with their clan-specific ancestors and totems appear to be an older layer » (1994a: 179). As mentioned above, the present-day distribution of the Mek peoples results in Heeschen's view from a sequence of migrations. This account of Mek migration accords with the overall westward movement of highlanders in western New Guinea, also supposed by Bromley $(1990)^{28}$. However, Heeschen opines further that at one stage the habitat of the Mek speakers extended further west, but that people, after their westward migrations, turned east (1994a: 180). Another eastward migration is suggested by Sims and Sims' observation that, at the time of their research, the Ketengban regarded the Bime valley as the heartland of their habitat, although it was located at its western end. With regard to mythical accounts of the past: as related above, also Afek travelled first from east to west, into what has become West Papua, to subsequently turn east again ${ }^{29}$. As related to Hylkema, the oral history of the Ngalum at Apmisibil, currently the westernmost Ok speakers, did not refer to a westward migration either. They traced their origin to the south, while they regarded Puncak Digul, to the southwest, as the centre of their world (Hylkema, 1974: 1, 422).

\section{Overview of Social Organisation}

In my perception, Eipo social organisation was a « configuration » (Pouwer 1966) of a number of heterogeneous elements. Eipo were firstly united because they shared the upper Eipomek valley as their habitat. The intensity of their agriculture allowed them close settlement. In my view, the Eipo opted for this mode of existence. They moreover expressed and contributed to their unity by ongoing interaction and by acts of manifold reciprocity. The effective social units were the neighbourhoods whether consisting of a single or of several settlements. Notwithstanding the centrality of the ancestor cult and its role in local organisation, neighbourhoods comprised male members of different clans. Many if not most clans were fissioned and their members lived over a wide area. They did not function as units, in line with the situation observed by Barnes in his generalising paper " African models in the New Guinea Highlands » (1962: 6). Instead, the local subclans did so. Also beyond settlements clan organisation counted for less than the links of affinity and kinship provided by current and previous marriages thus emphasising the horizontal aspect of kinship organisation (Pouwer, 1966: 276f). In addition, initiation provided links between men from different settlements and so did the occurrence of trade and of exchange feasts.

\section{Concluding Remarks}

In this section, I discuss the researchers' reflections on the Eipo and their way of life. What strikes me is their high regard for the Eipo themselves, while, in contrast, some, but certainly not all, of their comments on elements of their way of life are critical. I start with the latter, to end the section with the comments on the Eipo as persons and companions.

Several researchers comment negatively or ambivalently on aspects of Eipo culture. I mention Helfrich's (1978a) statement that Eipo

27. Michel's (1988) version of Ngalum prehistory is at variance with the above accounts.

28. But the direction of these population shifts contrasts with the long term « spread of peoples eastward through Melanesia » (Knauft, 1999: 151).

29. For another example from the same region, see Michel (1990: 15). 
material culture was « poor », even poorer than that of other Mek speakers. In the same vein, Koch (1984b: 137) writes on the one hand « The Malingdam culture - as is the culture of all Eipo - may perhaps be viewed as a marginal one in view of its simplicity (poverty) $»^{30}$. But in a recent personal communication (2003), he expressed appreciation that the Eipo were in need of so few material artefacts. Koch and Schiefenhövel (1989: 11) opine that Eipo houses showed that their builders had little interest in perfection and upgrading. And also according to Heeschen, in a recent statement, Eipo material culture was "extremely poor» (1998a: 22). About their oral traditions he wrote earlier (1990b: 11) that Eipo storytelling was not smooth, was unglatt, that their stories were "fragmentary» and their images again « poor ». However, in a paper dealing with Eipo singing published about the same time, Heeschen (1989b: 189) writes about the « diversity of the many songs and the richness of their images and symbols ».

Before turning to the positive comments, I would like to point out that several of the above remarks seem to lack factual basis. Firstly, Eipo material culture was hardly different from the material artefacts of other western New Guinea highlands ethnic groups. I make this geographical restriction because western New Guinea highlanders had material cultures that were less colourful and less elaborate than those of highlanders in Papua New Guinea (cf. Ploeg, on the Western Dani, 1969: 8). And although for example Dani built sturdier houses, and garden fences, than did the Eipo who spent the minimum of material, and not a great deal of care, on their construction, that seems to me to have been a cultural choice, not forced upon them by either the physical environment or their lack of building skills. I cannot see a reason why the Eipo could not have built sturdier houses and fences, had they wanted to. Interestingly, a film made by Simon and Helfrich (1987) shows a man making a forehead band on a weaving bow (also, Koch, 1984b: 31; Ohnemus, 1989). The technique used deviated from the various looping techniques that have been reported from all over the central highlands. Heeschen (pers. comm. 2002) remarks that this tool was rarely used among the Eipo, yet people knew and used it ${ }^{31}$.

Moreover, reading the texts that Heeschen collected, it is not clear to me why he felt, and how he assessed, that their imagery was poor, if that, in fact, is his final judgment. Many of the stories that he was told had earlier been secret ones, not to be told to an outsider. It seems likely that this influenced the way they were told. Moreover, Eipo told Heeschen a number of lengthy fairytales that were hardly fragmentary (1990b: 334f). In one of his most recent linguistic publications, written after years of field research in the course of two decades, Heeschen (1998a: 354-355) comments on his understanding of the Eipo language:

« In promising times I trust to being able to piece together Eipo utterances from whatever I have heard and from whatever has proved a success [...] in participating in their conversations [...]. In times of hopelessness, [...] I am far from even groping my way from 'intention to speaking' and equally far from understanding the native speakers. »

Heeschen subsequently gives an example of a text that he has to « brood over » and concludes:

«Perhaps the narrator [...] delighted in transforming a well-known myth into an abbreviated and condensed structure, which continues to harass the hearer unduly. » (ibidem)

Whatever else this example shows, it implies that Eipo speakers had a great mastery in making use of their language.

On the positive side, the authors emphasise the craftsmanship of the Eipo (Koch, 1984b: $135,138)$; the pleasure at least some had in repairing things, in making them useful tools again (Michel, 1983a: 124); their skill in making gardens in inhospitable terrain. Koch (pers. comm. 2003) stresses the positive aspect of their unpretentiousness, their inclination to « make do with the minimum of gear» (1978b). Schiefenhövel (1999: 275) describes their body decoration as " often spectacular» (as shown in Simon and Schiefenhövel, 1989f and 1989g). About Oleto's love song that I quoted on p. 22, Hiepko and

30. Die Malingdam-Kultur — wie die Eipo-Kultur insgesamt — ist in ihrer Schlichtheit («Armut») vielleicht als eine Marginalkultur zu werten...

31. It is not clear how widespread the technique is, or was. The weaving bow does not feature in Sillitoe's Made in Niugini (1988), an extensive exposition of the material cultures of Papua New Guinea highlanders. The fact that the tool apparently is or was a disposable, may have contributed to it being little noticed. Ohnemus (pers. comm. 2003), who was not a member of the Eipo research team, was asked to write the comments on the film featuring the technique, because she had, accidentally, observed the technique while in Tumolbil, among Ok-speakers and had published on it (Seiler-Baldinger and Ohnemus, 1986). Bercovitch told her that it was generally known among the Atbalmin. Also the Star Mountains frame shown in Kooijman 1962, plates 17 and 18, seems to require a weaving technique, unlike however the beading frame shown in Craig and Hyndman (1990: 240), known among Mountain Ok. I myself noticed the technique used by a Bokondini Dani man in the early 1960's. 
Schiefenhövel (1987: 21) write that «the force and the boldness of its metaphors withstand comparison with our literature ». It is not clear to me, though, why it would not, or what is the point of such a comparison.

The upshot is, however, that notably Helfrich (1978a) rates their way of life as marginal compared to the " great Highlands cultures, of for instance the Chimbu, the Ok, the Dani and so on ». Helfrich seems to suggest that the Eipo way of life was somehow deficient, at a lower level than that of other highlands peoples. If such a comment is at all feasible, it pertains to a way of life and not to those who at any moment in time sustain it. And it is made in answer to one or more yardsticks, implicit or explicit. Again, I cannot see reason to regard the Eipo way of life as « marginal », if only because they had a rich ritual life that could bring them to euphoria. The major difference, compared with Dani, Ok and Chimbu, seems to me one of social scale, in the case of at least most Ok cultures expressed in a regional cult. The same comment pertains to Eibl-Eibesfeldt, Schiefenhövel and Heeschen's (1989: 205) more general claim that highlands cultures are more « archaic» than « Austronesian ones ». They do not elaborate on this statement. In my own view, the Eipo had opted for a sober lifestyle as regards material culture. Rather than enlarging upon the range and the number of wealth items, they instead focused on maintaining, possibly improving upon, the habitat that their ancestors had bequeathed them. Their adoption of the sweet potato had enabled them to make more use of the higher reaches of their habitat, both for settlement and for cultivation. The increase in productivity that they had thus achieved, they may have used primarily to have more output available to entertain guests, especially during the exchange feasts with other villages, " the highlights in an Eipo's life ", referred to above (see p. 32).

But when they turn to the Eipo themselves, the researchers are very positive. Koch writes that the Eipo readily assisted each other. He found them cheerful and not easily distressed (1984b: 14). In the paper that he presented at the 1990 Seewiesen conference, he reflected on the fieldwork period and stated that his relationships with the Eipo had been very pleasant. He contrasted this with the relationships among some of the researchers. The Eipo, he writes, were «the best partners to imagine within the requirements of the intended research » (ibidem). Koch was touched that, at the end of his fieldwork, one of his closest Eipo collaborators accompanied him to the Bime valley, an area he did not know, at several days walk from the upper Eipomek. He went unarmed, so risked his life (1990: 7-8). Likewise Heeschen (1984a) points to the hospitality of the Eipo, their pervasive sharing - «Eipo are ashamed to eat without sharing» (1984a: 115) — and their concern about his well being.

In reading the ethnography, it seems to me that Koch was to the point in concluding that Eipo were a highly selective people, accepting or rejecting, as it suited them, the novelties that came their way (Koch, 1984b: 134). They had done so in the pre-colonial past, accepting for example sweet potato and tobacco as new crops ${ }^{32}$.

«Fundamentally, they were interested in keeping their own order of life - and we [the researchers] were very careful not to interfere with their wise conservatism. » (Koch, 1990: 7)

Several of the team members mention that the Eipo were prepared to grow the novel crops that they or other Europeans had brought along, such as European potatoes and maize, but that they would not eat some of them, not even in times of scarcity. On the other hand, newly introduced crops such as a pumpkin and a gherkin variety had become prized delicacies (Michel, 1983a: 87). Such selectiveness points to a strong sense of self. Stewart and Strathern (2001) conclude that people who see their past as a continuity, display " tenacity in selfidentifications $»$. Their insight is very applicable to the Eipo.

\section{BIBLIOGRAPHY}

I have divided the bibliography into three parts. The first one contains the publications of the Eipo team that I was able to trace. I list them whether or not I refer to them in the text. Included are the films produced. I refer to them by the number they received at the Institut für den Wissenschaftlichen Film, The Institute for Scholarly Films, Göttingen, that took part in their production. The films can be borrowed there. Most are part of the Encyclopaedia Cinematografica. As does the institute, I refer to the series with the letter 'E'. A minority belongs to another series of ethnographic films published by the Institute. These films are identified by the letter ' $D$ '. And many films are documented by papers in the

32. To mention an example regarding material culture: Eipo knew about pandanus leaf raincapes, but had not taken to them notwithstanding their wet climate. 
series Publikationen zu Wissenschaftlichen Filmen, section Ethnology, in this biblography referred to as PWF. Film and paper often do not have the same year of publication. Others have, unpublished, accompanying notes. These I have not listed. In addition to the publications, there are holdings of unpublished material in the Anthropological Museum, Museum für Völkerkunde, in Berlin (Koch, pers. comm. 2003), and in the Research Institute for Human Ethology, the Forschungsstelle für Humanethologie, in Andechs, Bavaria. The second part of the bibliography lists the papers presented at the 1990 conference "The Mek and their Neighbours ", held at Seewiesen, Bavaria. Both team members and invited outsiders presented papers. Most, however, have remained unpublished. The third part refers to other sources that I have quoted in the text.

The main publication series of the Eipo team is Mensch, Kultur and Umwelt im Zentralen Bergland von West-Neuguinea (Berlin; Dietrich Reimer Verlag). As I did in the main text of this essay, I refer in the bibliography to this series as MKU. I have added English translations of those German titles that I thought might be hard to understand for English readers.

\section{Published Writings and Films of the Eipo Team}

BLum, Paul, [J.P.], 1978. Forschungsprojekt Zoologie 2, in Staatliche Museen 1978, sheet 8.

—, 1979. Untersuchungen zur Tierwelt im Leben der Eipo im Zentralen Bergland von Irian- Jaya (WestNeuguinea), Indonesien [Research into the Role of the Animal Realm in the Life of the Eipo, Central Highlands of Irian-Jaya], MKU 2

—, 1983. Eipo (West-Neuguinea, Zentrales-Hochland) - Bauen einer Gewichtfalle [Setting up a Weight Trap], E2659.

—, 1989. Eipo (West-Neuguinea, Zentrales Hochland) Gartenarbeiten (Hochbeetbau) [Garden work (high mound cultivation)], PWF 7 (10), pp. 159-67. Paper accompanying Walter 1982.

BüCHI, Ernst C., 1978a. Forschungsprojekt physische Anthropologie, in Staatliche Museen 1978, sheet 9.

—, 1981. Physische Anthropologie der Eipo im zentralen Bergland von Irian Jaya. MKU 8.

EgGert, Brigitte, Templiner, Angelika and WARTWIG, Helga, 1978. Das östliche zentrale Bergland von West New Guina [Zwei Karten] [The eastern central highlands of west New Guinea] [two maps], in Staatliche Museen 1978, sheet $2 \mathrm{~b}$.

EibL-EIBESFELDT, Irenäus, 1976a. Menschenforschung auf neuen Wegen. Die Naturwissenschaftliche Betrachtung kultureller Verhaltensweisen [New Ways to Research People. The Scientific Approach to Cultural Sociality]. Wien, etc., Molden Verlag.
—, 1976b. Die Eipo - Steinzeitmenschen im 20. Jahrhundert [The Eipo - neolithic people in the 20th century], MPG Spiegel 6, pp. 29-30.

_, 1977. Patterns of greeting in New Guinea in Pacific Linguistics, Series C, no. 40: New Guinea Area Languages and Language Study, vol. 3: 'Language, Culture, Society and the Modern World', fascicle 1, pp. 209-247.

—, 1992. Eipo (West-Neuguinea, Zentrales Hochland) Demonstration des Rituellen Pflanzens einer Cordilyne [Demonstration of the Ritual Planting of a Cordilyne], E3037. Accompanying paper: EiblEibesfeldt 1994.

—, 1994. Demonstration des rituellen Pflanzens einer Cordilyne [Demonstration of the ritual planting of a cordilyne], PWF 9, pp. 13-25. Paper accompanying Eibl-Eibesfeldt 1992.

—, 1995a. Eipo (West-Neuguinea, Zentrales Hochland) Männertanz 'Sang Mote' [Men's Dance 'Sang Mote'], E2685. Accompanying paper: EiblEibesfeldt and Heeschen 1996.

—, 1995b. Eipo (West-Neuguinea, Zentrales Hochland) Männertanz 'Sang Mote' als Kinderspiel [Children Acting out the Men's Dance 'Sang Mote'], E2686.

_, 1995c. Kinderspiel: Rodeln auf Baumrinde [Children's Game: Sledging on Tree Bark], E2726.

_, 1995d. Kreiselspiel der Kinder [Top Spinning by Children], E2727.

_, 1995e. Kinder beim Ratespiel 'Mana' [Children Playing the 'Mana' Riddle], E2728.

—, 1995f. Kinderspiel: Bauen eines Hausmodels [Children's Game: Building a Miniature House], E2729.

_, 1995g. Flechtspiel 'Dungkula' [Plaiting Game 'Dungkula'], E2730.

_, 1995h. Eipo (West-Neuguinea, Zentrales Hochlad) - Bau und Demonstration von Gewichts und Schwippgalgenfallen [Construction and Demonstration of Weight and Noose Traps], E2761.

-, 1995i. Eipo (West-Neuguinea, Zentrales Hochland) Behandlung einer Pfeilwunde [Treating an Arrow Wound], E2800.

_, 1995j. Fadenspiel [Cat's Cradles], E2922.

—, 1995k. Eipo (West-Neuguinea, Zentrales Hochland) Zusammenwirken der Gemeinschaft beim Wohnhausbau [Community Co-operation during Housebuilding], E2957.

_, 19951. Erster Kontakt mit Weißen Besuchern - Fa [First Contact with White Visitors], E3035. Accompanying paper Eibl-Eibesfeldt 1995m.

—, 1995m. Erster Kontakt mit weißen Besuchern Fa [First contact with white visitors]'. Paper accompanying Eibl-Eibesfeldt 19951.

_, 1995n. Schlachten und Garen eines Schweins - Fa [Slaughtering and Cooking a Pig], E3036. Accompanying paper: Eibl-Eibesfeldt 1995o. 
_, 1995o. Schlachten und Garen eines Schweins $\mathrm{Fa}$ [Slaughtering and cooking a pig], PWF 9, pp. 4963. Paper accompanying Eibl-Eibesfeldt 1995n.

-, 1996. Eipo (West-Neuguinea, Zentrales Hochland) Behandlung eines Panaritiums [Treating a Panaritium]. E2923.

EibL-Eibesfeldt, Irenäus and Volker Heeschen, 1995. Die Frau Danto im Gespräch mit dem Linguisten V. Heeschen [Danto, Talking with the Linguist V. Heeschen], E2870.

—, 1996. Männertanz 'Sang Mote' [Men's Dance 'Sang Mote'], PWF 9, pp. 113-126. Paper accompanying Eibl-Eibesfeldt 1995a.

EibL-EIBESFELDT, Irenäus and Wulf SCHIEFENHÖVEL, 1978. Forschungsprojekt Humanethologie in Staatliche Museen 1978, sheet 14.

EibL-EIBESFELDT, Irenäus, Wulf SCHIEFENHÖVEL and Volker HeEsChen, 1989. Kommunikation bei den Eipo. Eine Humanethologische Bestandsaufnahme [Eipo Communication. A Human-Ethological Survey]. MKU 19.

HEESCHEN, Volker, 1978a. The Mek languages of Irian Jaya with special reference to the Eipo language, IRIAN. Bulletin of Irian Jaya Development 7 (2), pp. 3-46.

_, 1978b. The metalinguistic vocabulary of a speech community in the highlands of Irian Jaya (West New Guinea) in A. Sinclair et al. (eds), The Child's Conception of Language, Berlin; Springer, pp. 155187.

_, 1982. Some systems of spatial deixis in Papuan languages, in: J. Weissenborn and W. Klein (eds) Here and There. Cross-Linguistic Studies in Deixis and Demonstration, Amsterdam; Benjamins, pp. 81109.

—, 1983. Eipo (West-Neuguinea, Zentrales Hochland) - Singen bei der Arbeit [Singing While Working], E2522. Accompanying paper Heeschen $1989 \mathrm{~b}$.

—, 1984a. Durch Krieg and "Brautpreis" zur Freundschaft. Vergleichende Verhaltensstudien zu den Eipo und Yalenang [Friendship via warfare and "brideprice". A comparative study into Eipo and Yalenang sociality], Baessler-Archiv, n.s. 32, pp. 113-143.

_, 1984b. Intuitionen. Grammatische Gespräche in nichtakkulturierten Sprachgemeinschaften [Intuitions. Grammatical conversations in nonacculturated speech communities], Linguistische Berichte 94, pp. 27-44.

-, 1984c. Ästhetische Form und sprachliches Handeln [Aesthetic form and speech behaviour], in I. Rosengren (ed.), Sprache und Pragmatic. Lunder Symposium 1984, Stockholm, Almqvist and Wiksell, pp. 387-411.

—, 1985a. Probleme der rituellen Kommunikation [Problems of ritual communication], in J. Rehbein. (ed.) Interkulturelle Kommunikation, Tübingen; Narr, pp. 150-165.
_, 1985b. Die Yale Sprache, eine Papua Sprache [The Yale language, a Papuan language], Studium Linguistik 16, pp. 35-45.

—, 1986a. Das Tonarchiv der Forschungsstelle für Humanethologie, Anthropos 81, pp. 292-298.

—, 1986b. Die bessere Schöpfung. Mission bei den Eipo und Yalenang [The better creation. Missionising among the Eipo and the Yalenang], Zeitschrift für Mission 12, pp. 202-208.

_, 1987a. Rituelle kommunikation in verschiedenen Kulturen, Zeitschrift für Literaturwissenschaft und Linguistik 65, pp. 35-45.

_, 1987b. Oben und Unten. Die Kategorisierung der Umwelt in den Sprachen Neuguineas [Above and below. Categorisation of the environment in New Guinea languages], in M. Münzel (ed.), Neuguinea. Nützung und Deutung der Umwelt, Frankfurt, Museum für Völkerkunde, pp. 599-618.

—, 1989a. Geschichte(n) sehen - Feldforschung in Irian Jaya [Seeing stories - Field research in Irian Jaya], in R. Aster, H. Merkens and M. Repp (eds), Teilnehmende Beobachtung. Werkstattberichte und Methodologische Reflexionen, Frankfurt, Campus Verlag, pp. 57-70.

—, 1989b. Eipo (West-Neuguinea, Zentrales Hochland) Singen bei der Arbeit [Singing while working], PWF 7 (2), pp. 183-194. Paper accompanying Heeschen 1983.

—, 1990b. Ninye Bún. Mythen, Erzählungen, Lieder und Märchen der Eipo [Ninye Bún. Myths, Stories, Songs and Fairytales of the Eipo], MKU 20.

—, 1992a. A Dictionary of the Yale (Kosarek) language (with sketch of Grammar and English Index), MKU 22.

_, 1992b. The position of the Mek languages of Irian Jaya among the Papuan Languages; history, typology, and speech, Bijdragen tot de Taal-, Land-en Volkenkunde 148, pp. 465-488.

_, 1994a. Mythen und Wandergeschichten der MekLeute im Bergland von West-Neuguinea (Irian Jaya, Indonesien) [Myths and migration stories of the Mek people in the highlands of west New Guinea], in B. Hauser-Schäublin (ed.), Geschichte und Mündliche Überlieferungen in Ozeanien. Basler Beiträge zur Ethnologie 37, Basel, Ethnologisches Seminar der Universität und Museum für Völkerkunde, pp. 161-184.

—, 1994b. Das kelabi- (sabalhe-) Kultbild im MekGebiet, Irian Jaya, Indonesien, Baessler-Archiv, n.s. 42, pp. 131-56.

-, 1994c. How long are clauses and sentences in a Papuan language like Eipo?, in G.P. Reesink (ed.), Topics in Descriptive Papuan Linguistics. Semaian 10, pp. 50-74.

_, 1997. Relativities: use and non-use of spatial reference among the Yale speakers in Irian Jaya (West New Guinea), in G. Senft (ed.), Referring to Space. Studies in Austronesian and Papuan Languages, Oxford, Clarendon Press, pp. 175-196. 
-, 1998a. An Ethnographic Grammar of the Eipo Language Spoken in the Central Mountains of Irian Jaya (West New Guinea), Indonesia. MKU 23.

_, 1998b. New Guinea myths and fairytales seen from the Irian Jaya mountains, in J. Miedema, et al. (eds), Perspectives on the Bird's Head of Irian Jaya, Amsterdam, Rodopi, pp 291-312.

_, 2001a. The narration 'instinct'. Everyday talk and aesthetic forms of communication, in $\mathrm{H}$. Knoblauch and H. Kotthoff (eds), Verbal Art across Cultures. The Aesthetics and Proto-Aesthetics of Communication, Tübingen, Gunter Narr Verlag. pp. 137-165.

_, 2001b. Die Angst des Linguisten vor der Humanethologie, oder Mythen und Märchen in der Biologie des menschlichen Verhaltens [Linguists' fear of human ethology, or myths and fairytales in the biology of human sociality] in C. Sütterlin and F.K. Salter (eds), Irenäus Eibl-Eibesfeldt. Zu Person und Werk, Frankfurt am Mainz, Peter Lang, pp. 144-53.

HeEsCHEN, Volker and Irenäus EIBL-EIBESFELdT 1995. 'Dit' Gesang der Männer [Men Singing 'Dit'], E2833.

HeEsCHEN, Volker and Wulf SchIEFENÖVEL 1983. Wörterbuch Eipo-Deutsch-Englisch, MKU 6.

HeEsCHEN, Volker Wulf SCHIEFENHÖVEL and Irenäus EIBL-EIBESFELDT 1980. Requesting, giving, and taking: the relationship between verbal and nonverbal behaviour in the speech community of the Eipo, Irian Jaya (West New Guinea), in M.R. Key (ed.), The Relationship between Verbal and Nonverbal Communication. Contributions to the Sociology of Language. The Hague, etc. Mouton, pp. 139-166.

Helfrich, Klaus, 1978a. Forschungsprojekte Ethnologie - Die "Hochland-Kultur" von Neuguinea und die Kultur der Eipo, in Staatliche Museen 1978, sheet 16

-, 1978b. Forschungsprojekte Ethnologie - Religion, in Staatliche Museen 1978, sheet 21.

—, 1978c. Forschungsprojekte Ethnologie - Gesel1schaft [Society], in Staatliche Museen 1978, sheet 27.

-, 1989a. Eipo (West-Neuguinea, Zentrales Hoch land) - Speisenbereitung in Erdöfen und Festliche Bewirtung [Cooking Food in Earth Ovens and Festive Hospitality], E2653.

_, 1989b. Neubau einer Familienhütte in Talim Eipo (West-Neuguinea, Zentrales Hochland) [Rebuilding a Family Hut in Talim - Eipo], D1436.

_, 1989c. Arbeit mit dem Steinbeil in Talim — Eipo (West-Neuguinea, Zentrales Hochland) [Working with a Stone Adze in Talim], D1437.

—, 1989d. Kinderspiel: Bauen einer Hängebrücke Eipo (West-Neuguinea, Zentrales Hochland) [Children Acting out theConstruction of a Suspension Bridge], D1438.

Helmcke, Dietrich, Volker Jacobshagen and Peter GIESE 1978. Forschungsprojekt Geowissenschaften, in Staatliche Museen 1978, sheet 4.
HelmCKe, Dietrich, 1979. Das Entwässerungssystem der Nord-Seite des Zentralgebirges von IrianJaya (Indonesien) zwischen Hablifuri und Sepik nach LANDSAT-Szenen [The Drainage System north of the Central Divide in the Central Highlands of Irian Jaya as Shown by LANDSAT], MKU 4.

—, 1983. Die Trimetrogon-Luftbilder der USAF von 1945 — die Älteste Dokumente über das EipomekTal und seine Umgebung (West-Neuguinea), Indonesien [The 1945 Trimetrogon Aerial Photographs the Oldest Documents about the Eipomek Valley and its Environs], MKU 14

Helmcke, Dietrich, Gerhard PöHLmann and Joachim Pohlmann 1983. Die Satelliten-bildkarte 1:500.000 von Zentral-Neuguinea (Östliche Jayawijaya- und westliche Sepik-Region) [The Satellite Based Map 1:500,000 (Eastern Highlands of West New Guinea and West Sepik Area)], MKU 13.

Hiepko, Paul and Wulf Schiefenhövel 1985. Die Pflanzenwelt aus der Sicht der Eipo (WestNeuguinea) [The world of plants as seen by the Eipo], in E. Schröder (ed.), Ethno-Botanik, Special Publication of Curare, Braunschweig and Wiesbaden, Vieweg and Sohn, pp. 283-288.

HiEPKo, Paul and Wulf SCHIEFENHÖVEL 1987. Mensch und Pflanze. Ergebnisse Ethnotaxonomischer und Ethnobotanischer Untersuchungen bei den Eipo, Zentrales Bergland von Irian Jaya (West-Neuguinea), Indonesien [People and Plants. Results of Ethnotaxonomic and Ethnobotanical Research among the Eipo, Central Highlands of Irian Jaya], MKU 5.

Hiepko, Paul and Wolfram Schultze-Motel 1981. Floristische und Ethnobotanische Untersuchungen im Eipomek-Tal, MKU 8.

HoFfmanN, Gert 1978. Forschungsprojekt Klimatologie, in Staatliche Museen 1978, sheet 5.

Hoffmann, G. and M. 1985. Klimabeobachtungen in Eipomek [Climatic Observations in Eipomek], Part 1, MKU 9a.

_, 1989. Klimabeobachtungen in Eipomek, Part 2, MKU 9b.

JÜPTNER, Horst 1978. Forschungsprojekt Tropenmedizin, in Staatliche Museen 1978, sheet 12.

-, 1983. Tropenmedizinische Untersuchung der Eipo im Zentralen Bergland von Irian Jaya (WestNeuguinea), Indonesien, MKU 12.

KocH, Gerd, 1977. Anatomie einer Steinzeitkultur. Die Eipo. Deutsches Forschungsprojekt auf Neuguinea [Anatomy of a stone age culture. The Eipo. A German research project in New Guinea], Bild der Wissenschaft no. 9, pp. 46-59.

_, 1978a. Forschungsprojekte Ethnologie. Kleidung und Schmuck [Clothing and Finery], in Staatliche Museen 1978, sheet 17.

-, 1978b. Forschungsprojekte Ethnologie. Wirtschaftsgerät [Economic Tools], in Staatliche Museen 1978 , sheet 18 . 
—, 1978c. Forschungsprojekte Ethnologie. Siedeln und Wohnen [Settlement and Housing], in Staatliche Museen 1978, sheet 20.

—, 1979a. Das West-Irian-Projekt, Jahrbuch Preußischer Kulturbesitz 15, pp. 59-88.

—, 1979b. Steinzeit heute. Sonderausstellung der Abteilung Südsee des Museums für Völkerkunde [The stone age today. A special exhibition of the Pacific section of the Anthropology Museum], in Berliner Museen. Berichte aus den Staatlichen Museen Preußischer Kulturbesitz, dritte Folge, 15.

—, 1979c. Besucherbefragung im Museum (Sonderausstellung Steinzeit Heute. Forschungen im Bergland von Neuguinea) [Opinion poll among visitors (Special exhibition Stone Age now. Research in Highland New Guinea)], Baessler-Archiv, n.s. 27, pp. 1-134.

—, 1980. Das West-Irian Project. Schwerpunktprogramm der DFG [The West Irian project. A focal programme of the German Research Organization], in Mitteilungen der Koordinierungsstelle für gegenwartsbezogen Ost- und Südasienforschung 33, Hamburg; Deutsche Gesellschaft für Ost-und Südasienkunde.

—, 1984a. Zur Einführung [Introductory], in MKU 15 [Koch wrote an identical introduction for most of the MKU volumes. It seemed appropriate to me to quote from the one he inserted in his own monograph].

—, 1984b. Malingdam. Ethnographische Notizen über einen Siedlingsbereich im oberen Eipomek-Tal, zentrales Bergland von Irian Jaya (West-Neuguinea), Indonesien [Ethnographic Notes about a Neighbourhood in the Upper Eipomek Valley, Central Highlands of Irian Jaya], MKU 15.

_, 1985a. Eipo (West-Neuguinea, Zentrales Hochland) - Arbeit mit dem Steinbeil im MalingdamBereich [Working with the Stone Adze in Malingdam Neighbourhood], E2637.

_, 1985b. Eipo (West-Neuguinea, Zentrales Hochland) - Flechtspiel 'Tetim Aik' [Plaiting game 'tetim aik'], E2638.

—, 1985c. Eipo (West-Neuguinea, Zentrales Hochland) — Arbeiten im Gartenland: Pflegen, Ernten und Pflanzen von Taro [Work in the Garden: Tending, Harvesting and Planting Taro], E2639. Accompanying paper Koch 1987a.

-, 1985d. Eipo (West-Neuguinea, Zentrales Hochland) - Terrassieren und Bepflanzen eines Hanges (Wiederbewirtschaftung von Brachland) [Terracing and Planting a Slope (Re-cultivation of Fallow Land)], E2640. Accompanying paper Koch 1987b.

—, 1985e. Eipo (West-Neuguinea, Zentrales Hochland) - Neubau einer Familienhütte in Imarin [Building a Family Hut in Imarin], E2641.

-, 1985f. Eipo (West-Neuguinea, Zentrales Hochland) - Feuersägen [Fire Making with the Fire Saw], E2675.

—, Zupfen [Plucking Beard Hair], E2676.
—, 1985h. Eipo (West-Neuguinea, Zentrales Hochland) Vorbereitingen zum Kampf [Preparations for a Fight], E2713.

_, 1986. Versuche mit Menschen in der Ethnologie - Völkerkundige Untersuchungen: Möglichkeiten und Probleme [Undertakings with people in ethnology — anthropological research: feasibilities and problems], in $\mathrm{H}$. Helmchen and R. Winau (eds), Versuche mit Menschen in Medizin, Humanwissenschaften und Politik, Berlin, New York, W. de Gruyter, pp. 235-255.

—, 1987a. Eipo (West-Neuguinea, Zentrales Hochland) Arbeiten im Gartenland: Pflegen, Ernten und Pflanzen von Taro [Work in swiddens: tending, harvesting and planting taro], PWF 7 (3), pp. 33-44. Paper accompanying Koch 1985c.

—, 1987b. Eipo (West-Neuguinea, Zentrales Hochland) Terrassieren und Bepflanzen eines Hanges (Wiederbewirtschaftung von Brachland) [Terracing and planting of a slope (re-cultivation of fallow land)], PWF 7 (4), pp. 47-62. Paper accompanying Koch 1985d.

-, 1988. The West Irian Project, Visual Anthropology 1, pp. 281-285.

Koch, Gerd and K. Helfrich, 1978a. Planung [Planning], in Staatliche Museen 1978, sheet 1.

—, 1978b. Bisherige Entwicklung [Implementation so far], in Staatliche Museen 1978, sheet 2a.

—, 1978c. Vorläufige Ergebnisse [Preliminary Results], in Staatliche Museen 1978, sheet 3.

KocH, Gerd and Wulf SchiEFEnHövel, 1979. Eipo (West-Neuguinea, Zentrales Hochland) Neubau des sakralen Männerhauses in Munggona [Rebuilding the Sacred Men's House in Munggona]. E2475. Accompanying paper Koch and Schiefenhövel 1987.

—, 1987. Eipo (West-Neuguinea, Zentrales Hochland) Neubau des sakralen Männerhauses in Munggona [Rebuilding the sacred men's house in Munggona]', PWF 7 (4), pp. 131-156. Paper accompanying Koch and Schiefenhövel 1979. The paper contains an English version of the film commentary spoken in German.

—, 1989. Die Eipo — eine kürze Einführung [The Eipo - a short introduction], in I. Eibl-Eibesfeldt, W. Schiefenhövel and V. Heeschen 1989, pp. 9-12.

KonRAD, Gunter, 1976. Krankenbehandlung durch Geisterbeschwörung [Treating a patient by exorcising spirits], in H. Harrer (ed.), Unter Papuas. Mensch und Kultur seit ihrer Steinzeit, Innsbruck/Frankfurt, Fischer Verlag, pp. 236-244.

—, 1978. Forschungsprojekt Algemeinmedizin [General medical research], in Staatliche Museen 1978, sheet 11.

—, 1982. Entfernen der Barthaare durch Züpfen Bime, West Neuguinea [Depilating Beard Hair by Plucking], D1439.

-, 1989a. Bime (West-Neuguinea, Zentrales Hochland) - Magische Behandlung von Kopf - und Nac- 
kenschmerzen mit Bananenblättern [Magic Treatment of Headaches and Neckaches by Means of Banana Leaves], E2652.

_, 1989b. Bime (West-Neuguinea, Zentrales Hochland) - Magische Behandlung einer Lungenentzündung mit Schildkrötenknochen [Magic Treatment of Pneumonia by Means of Turtle Bones], E2655.

—, 1989c. Bime (West-Neuguinea, Zentrales Hochland) - Magische Behandlung von Kopf-und Schulterschmerzen mit Schweinefett [Magic Treatment of Headaches and Shoulderaches by Means of Pig Fat], E2657.

-, 1989d. Bime (West-Neuguinea, Zentrales Hochland) - Magische Behandlung von Kopfschmerzen mit einem Stein [Magic Treatment of Headache by Means of a Stone], E2658.

KonRad, Gunter and Ursula KonRad, 1976. Bildhafte Darstellungen aus dem Bime-Tal, in H. Harrer (ed.) Unter Papuas. Mensch und Kultur seit ihrer Steinzeit, Innsbruck / Frankfurt; Fischer Verlag, pp. 342-3.

_, 1989. Bime (West-Neuguinea,Zentrales Hochland) - Geburtsverlauf bei einer Erstgebärenden mit Klumpfußmisbildung des Neugeborenen [Birth of a child with a clubfoot by a primiparous mother], E2651.

Michel, Thomas, 1978. Forschungsprojekte Ethnologie. Krisenbewältiging nach den beiden Erdbebenkatastrophen im Jahre 1976 [Overcoming the crisis following the two catastrophic earthquakes in 1976], in Staatliche Museen 1978, sheet 23.

—, 1981. Tabak in Neuguinea, Ethnologica 9 (1), pp. 258-262.

-, 1983a. Interdependenz von Wirtschaft und Umwelt in der Eipo-Kultur von Moknerkon, Irian Jaya (West-Neuguinea, Indonesien) [Interdependence of Economy and Environment in the Culture of the Moknerkon Eipo, Irian Jaya], MKU 11.

—, 1983b. Rückkehr zum Normalen Leben nach einem Erdbeben [Back to Normal Life after an Earthquake], E2718. Accompanying paper: Michel, with Koch and Schiefenhövel, 1989.

_, 1987. Taro and Süßkartoffel auf Neuguinea, in $\mathrm{H}$. Münzel (ed.) Neuguinea. Nutzung und Deutung der Umwelt. Exhibition guide, Frankfurt; Museum für Völkerkunde, pp. 227-237.

-, 1988b. Eipo (West-Neuguinea, Zentrales Hochland) - Baumfällen mit dem Steinbeil [Cutting down Trees with a Stone Adze ], E2704.

-, 1989a. Eipo (West-Neuguinea, Zentrales Hochland) - Gartenbauarbeiten im Sumpfgelände [Making a Garden in a Swamp], E2705.

_, 1989b. Eipo (West-Neuguinea, Zentrales Hochland) Pflanz-Zauber [Planting Magic], E2706.

—, 1989c. Eipo (West-Neuguinea, Zentrales Hochland) Baumbestattung einer Frau [Tree Burial of a Woman], E2707.
-, 1989d. Eipo (West-Neuguinea, Zentrales Hochland) Bauen einer Brücke [Building a Bridge], E2708.

_, 1989e. Eipomek 1986, W1992.

—, 1989f. Gartenarbeiten am Steilhang — Eipo (West-Neuguinea, Zentrales Hochland) [Making a Garden on a Steep Slope], D1472.

Michel, Thomas and R. Mischung, 1984. Umweltverhalten von Bergvölkern in Thailand und Neuguinea [Ecological relationships of highlands peoples in Thailand and New Guinea], Forschung Frankfurt. Wissenschaftsmagazin der J.W. GoetheUniversität, no. 4, pp. 2-8.

Michel, Thomas (with Gerd KOCH and Wulf SCHIEFENHÖVEL), 1989. Eipo (West-Neuguinea, Zentrales Hochland) Rückkehr zum normalen Leben nach einem Erdbeben [Return to normal life after an earthquake], PWF 7 (13), pp. 197-221. Paper accompanying Michel 1983b.

NelKe, Wolfgang, 1978. Forschungsprojekte Ethnologie - Waffen [Weapons], in Staatliche Museen 1978, sheet 19 .

—, 1978. Forschungsprojekte Ethnologie — Spiele [Games], in Staatliche Museen 1978, sheet 22.

_, 1989a. Jagd mit Pfeil und Bogen auf Beutelmäuse - Fa [Hunting Small Marsupials with Bow and Arrow], D1484.

_, 1989b. Bau einer Schwippgalgenfalle - Fa [Constructing a Noose Trap], E2774.

—, 1989c. Zubereiten und Verspeisen van Beutelmäusen - Fa [Cooking and Eating Small Marsupials], E2776.

—, 1989d. Arbeiten bei der Errichtung eines neuen Dorfes nach einem Erdbeben - Fa [Building a New Village after an Earthquake], E2878.

—, 1989e. Flechten eines Schweinestrickes - Fa[Twisting a Pig Rope], D1482.

—, 1989f. Bauen von Brücken - Fa [Construction of Two Bridges], D1483.

—, 1989g. Magische Heilbehandlung einer Kopfverletzung - Fa [Treating a Head Injury by Means of Magic], E2773.

—, 1989h. Kinderspiel 'Frug-Frugana' - Fa- [Children's Game 'Frug-Frugana'], E2775.

OhNemus, Sylvia, 1989. Eipo (West-Neuguinea, Zentrales Hochland) Herstellen eines Perlenbandes in Halbwebtechnik [Making a band set with beads with a semi-weaving technique], PWF 7 (14), pp. 225-236. Paper accompanying Simon and Helfrich 1987.

Plarre, Werner, 1978. Forschungsprojekt Biologie der Kulturpflanzen [Research project biology of cultigens], in: Staatliche Museen 1978, sheet 26.

_, 1995. Evolution and variability of special cultivated crops in the highlands of West New Guinea (Irian Jaya) under present Neolithic conditions, Plant Genetic Resources Newsletter, no 102, pp. 1-13. 
RöLL, Werner, 1980. Siedlung und Agrarwirtschaft von Pygmäen Steinzeitlicher Kulturstufe im zentralen Bergland von Irian Jaya, Indonesien [Settlement and agrarian economy of stone age pygmies in the central highlands in Irian Jaya], in W. Röll, U. Scholz and H. Uhlig (eds), Wandel Bäuerliche Lebensformen in Südostasien. Giessener Geografische Schriften, no. 48, pp. 111-120.

—, 1984. Die Eipo: Steinzeitlicher Pflanzer in Irian Jaya [The Eipo: stone-age cultivators in Irian Jaya], in Im Gespräch. Quarterly of the Konrad Adenauer Foundation, 46 (1), pp. 22-23.

RöLL, Werner and Gerd ZimmermanN, 1979. Untersuchungen zur Bevölkerungs-, Siedlungs- und Agrarstruktur im Zentralen Bergland von Irian Jaya (WestNeuguinea), Indonesien [Research into the Population, Settlement and Agrarian Structures in the Central Highlands of Irian Jaya], MKU 1.

SCHIEFENHÖVEL, Grete, 1978. Forschungsprojekt Zahnmedizin [Research project dentistry], in Staatliche Museen 1978, sheet 10.

SChIEFEnHÖVEL, Grete and Wulf SCHIEFEnHÖVEL, 1978. Vorgänge bei der Geburt eines Mädchens und Änderung der Infantizid-Absicht. Eipo. Irian Jaya (West-Neuguinea) [Birth of a girl and giving up the intention to commit infanticide], Homo 29, pp. 121138.

_, 1990. Wie zeichnen unbeeinflußte Bewohner des Berglandes von Neuguinea? [What drawings do uninfluenced inhabitants of the New Guinea highlands make?], in H. Daucher (ed.) Kinder denken in Bildern, München / Zürich, Piper, pp. 219227.

—, 1993. Das Kind auf die Erde legen [Laying down the child on the earth], in Schiefenhövel, Uher and Krell (eds), 1993, pp. 70-77.

—, 1997. Eipo (West-Neuguinea, Zentrales Hochland). Vorgänge bei der Geburt eines Mädchens und Änderung der Infantizid-Absicht [Birth of a Girl and Alteration of the Intention to Commit Infanticide], E 2680. Accompanying paper Schiefenhövel, W., $1997 \mathrm{c}$.

SchiEFEnhövel, Wulf, 1976. Die Eipo Leute des Berglands von Indonesisch-Neuguinea. Kürzer Überblick über den Lebensraum und seine Menschen. Einführung zu den Eipo-Filmen des Humanethologisches Filmarchivs der Max-Planck-Gesellschaft [The Eipo of the highlands of Indonesian New Guinea. A short synopsis of habitat and people. Introducing the Eipo films in the human ethological film archive of the Max Planck Society], Homo. Internationale Zeitschrift für die Vergleichende Forschung am Menschen 26 (1), pp. 263-275.

-, 1978. Forschungsprojekt Ethnomedizin, in Staatliche Museen 1978, sheet 13.

—, 1979. The Eipo, members of the Mek group in the highlands of Irian Jaya', Bulletin of Irian Jaya Development 7 (2), pp. 47-67.
_, 1980a. Verarbeitung von Schmerz und Krankheit bei den Eipo, Hochland von West-Neuguinea - ethnomedizinische und humanethologische Aspekte [Handling of grief and disease among the Eipo, highlands of west New Guinea - ethnomedical and human ethological aspects], Medische Psychologie 6, pp. 219-234.

—, 1980b. Primitive childbirth — anachronism or challenge to "modern" obstetrics?, in A. Ballabriga and A. Gallart (eds) Proceedings of the 7th European Congress of Perinatal Medicine. pp. 40-49.

-, 1982a. Results of ethnomedical fieldwork among the Eipo, daerah Jayawijaya, Irian Jaya, with special reference to traditional giving of birth, Medika 11, pp. 829-843.

_, 1982b. Kindliche Sexualität, Tabu und Schamgefühl bei "primitiven" Völkern [Child sexuality, taboo and shame among "primitive" peoples], in T. Hellbrügge (ed.) Die Entwicklung der kindlichen Sexualität, München, etc., Urban and Schwarzenberg, pp. 145-163.

—, 1983a. Of body and soul - about the concept of Man among the Eipo, Mek language group, Highlands of Irian Jaya (West New Guinea), Bikmaus 4 (1), pp. 87-92.

-, 1983b. Geburten bei den Eipo [Births among the Eipo], in W. Schiefenhövel and D. Sich (eds), Die Geburt aus ethnomedizinischer Sicht, Wiesbaden; Vieweg, pp. 41-56.

—, 1984a. Bindung und Lösung - Sozialisationspraktiken im Hochland von Neuguinea [Bonding and unbinding - socialisation in the highlands of New Guinea], in Ch. Eggers (ed.), Bindungen und Besitzdenken beim Kleinkind, München, etc., Urban and Schwarzenberg, pp. 51-80.

—, 1984b. Geburt bei den Eipo in West-Neuguinea [Giving birth among the Eipo in West New Guinea], Sexualpädagogik und Familienplanung 1, pp. 6-7.

-, 1984c. Preferential female infanticide and other mechanisms regulating population size among the Eipo, in N. Keyfitz (ed.), Population and Biology, Liège; Ordina Editions, pp. 169-92.

_, 1984d. Der Witz als transkulturelles ästhetisches Problem - Versuch einer biologischen Deutung [Joking as a transcultural aesthetic problem attempt at a biological interpretation], Mitteilungen der Anthropologischen Gesellschaft in Wien 114, pp. 31-6.

—, 1984e. Geburtsbeobachtungen bei einem Naturvolk [Observations of births among a people of nature]. Tutzinger Materialien no. 13, pp. 2-19.

-, 1985a. Sterben und Tod bei den Eipo im Hochland von West-Neuguinea [Dying and death among the Eipo in the highlands of West New Guinea], in D. Sich et al. (eds) Sterben und Todeine Kulturvergleichende Analyse, Wiesbaden / Braunschweig,Vieweg, pp. 191-208.

_, 1985b. Streßfaktoren und Streßlösung in industrialisierten und traditionellen Gesellschaften - 
Beispiele aus Feldbeobachtungen in Neuguinea [Stress factors and stress solution in industrialised and in traditional societies - Examples from observations made in the field, in New Guinea], Mitteilungen der Anthropologische Gesellschaft in Wien 115, pp. 41-52.

—, 1986a. Jugend zwischen Aggression und Anpassung - Ergebnisse humanethologischer Feldforschung [Youth between aggression and adaptation - results of human ethological field work], in $\mathrm{H}$. Remschmidt (ed.), Jugend und Gesellschaft - Realitätsbewältigung, Krisen und Auswege, Frankfurt, Wissenschaftliche Verlagsgesellschaft, pp. 67-80.

—, 1986b. La agresión y el control de la agresión: un ejemplo de Nueva Guinea y algunas consideraciones generales sobre etologia humana [Aggression and its control: an example from New Guinea and some general observations about human ethology], in J. Sanmartin et al. (eds) La Sociedad Naturalizada - Genética y Conducta, Valencia, Tirant lo Blanch, pp. 309-327.

—, 1986c. Populationsdynamische Homöostase bei den Eipo in West-Neuguinea [Zero population growth among the Eipo], in O. Kraus, (ed.), Regulation, Manipulation und Explosion der Bevölkerungsdichte, Veröffentlichungen der Joachim Jungius-Gesellschaft der Wissenschaften, no. 53, Göttingen, Vandenhoek and Ruprecht, pp. 53-72.

—, 1986d. Bauen ohne Architect. Siedlungen und Häuser in Melanesien [Building without architects. Settlements and houses in Melanesia], Arcus (2), pp. 77-83.

_, 1987. Stress factors and stress coping among inhabitants of New Guinea, in F. Lolas and H. Mayer (eds) Perspectives on Stress and Related Topics, Berlin, etc. Springer, pp. 33-43.

-, 1988a. Geburtsverhalten und Reproduktive Strategien der Eipo. Ergebnisse humanethnologischer und ethnomedizinischer Untersuchungen im zentralen Bergland von Irian Jaya (West-Neuguinea), Indonesien. [Social Processes Occurring at Birth and Reproductive Strategies among the Eipo, MKU 16.

_, 1988b. Ethnomedical film documentation among the Eipo, highlands of West New Guinea, Visual Anthropology 1, pp. 341-348.

_, 1989a. Reproduction and sex-ratio manipulation through preferential female infanticide among the Eipo, highlands of West New Guinea, in A. Rasa, C. Vogel and E. Voland (eds) The Sociobiology of Sexual and Reproductive Strategies, London; Chapman and Hall, pp. 170-193.

-, 1989b. Eipo (West-Neuguinea, Zentrales Hochland). Genu $\beta$ von Pflanzensalz [Consumption of Salt Extracted from Plants], E2566.

_, 1991a. Die Mek und ihre Nachbarn. Internationale Konferenz über Neuguinea-Forschungen [The Mek and their neighbours. An international conference on research in New Guinea], Wissenschaft und Fortschritt 41, pp. 21-25.
—, 1991b. Eipo, in T. E. Hays (ed.), Encyclopedia of World Cultures, Vol 2, Oceania, Boston, MA, G.K.Hall, pp. 55-59.

—, 1993a. Die Eipo, in: Schiefenhövel, Uher and Krell (eds), 1993, pp. 26-35.

-, 1993b. Schön von innen und aussen [Attractive, on the inside and the outside], in Schiefenhövel, Uher and Krell (eds), 1993, pp. 190-5.

—, 1994. Formen nichtsprachlicher Kommunikation [Forms of non-verbal communication], in W. Schiefenhövel et al. (eds) Zwischen Natur und Kultur. Der Mensch in seinen Beziehungen, Stuttgart, TRIAS Thieme Hippocrates Enke, pp. 109-133.

-, 1995a. Eipo (West-Neuguinea, Zentrales Hochland). Geburt eines Mädchens einer Primipara [A Primipara Gives Birth to a Girl], E2681. Accompanying paper Schiefenhövel 1997d.

-, 1995b. Eipo (West-Neuguinea, Zentrales Hochland). Schwierige Erstgeburt [A Difficult First Birth], E2831. Accompanying Paper Schiefenhövel 1997 e.

-, 1996a. We could be short of food. Food and the preoccupation with food in the Eipo society, in I. Gonzales Turmo and P.R. de Solis (eds) Antropología de la Alimentacion: Nuevos Essayos sobre la Dieta Mediterránea, Sevilla, Pinelo, pp. 265-276.

_, 1996b. Anfertigen eines Rückenschmucks [Making a back ornament], PWF 9, pp. 129-149. Paper accompanying Simon and Schiefenhövel 1983a.

-, 1996c. Durchbohren der Nasenscheidewand [Piercing the septum], PWF 9, pp. 153-163, 170174. Paper accompanying Simon and Schiefenhövel 1989c.

_, 1996d. Durchbohren des Ohrläppchens [Piercing the earlobe], PWF 9, pp. 153-163, 175-178. Paper accompanying Simon and Schiefenhövel 1989d.

_, 1996e. Behandlung einer infizierten Wunde [Treating an infected Wound], PWF 9, pp. 153-163, 167169. Paper accompanying Simon and Schiefenhövel 1989 b.

-, 1996f. Wundbehandlung mit Schweinefett und durch Wärmeanwendung [Treating a wound with pig fat and by applying heat] PWF 9, pp. 153-163, 164-166. Paper accompanying Simon and Schiefenhövel 1989a.

-, 1997a. Reactions to cultural change among the Eipo in the highlands of West-New Guinea', in D.V. Joiris and D. Laveleye (eds), Les peuples des forêts tropicales. Systèmes traditionelles et développement rural en Afrique équatoriale, grande Amazonie et Asie du sud-est, Bruxelles, Guyot, pp. 220-227.

—, 1997b. Geburten [Births], PWF 9, pp. 205-214.

_, 1997c. Vorgänge bei der Geburt eines Mädchens und Änderung der Infantizid-Absicht [The birth of a girl and alteration of the intention to commit infanticide], PWF 9, pp. 215-225. Paper accompanying G. and W. Schiefenhövel 1997. 
—, 1997d. Geburt eines Mädchen einer Primipara [A primipara gives birth to a girl], PWF 9, pp. 226-236. Paper accompanying Schiefenhövel 1995a.

—, 1997e. Schwierige Erstgeburt [A difficult first birth] PWF 9, pp. 237-252. Paper accompanying Schiefenhövel 1995b.

-, 1998a. Traditional use of tropical biodiversity in Melanesia, in W. Barthlott and M. Winiger (eds), Biodiversity. A Challenge for Development Research and Policy, Berlin, etc., Springer, pp. 157-172.

-, 1998b. Indoctrination among the Eipo of the Highlands of West-New Guinea, in I.EiblEibesfeldt and F. Salter (eds), Indoctrinability, Ideology and Warfare: Evolutionary Perspectives, Oxford and Providence, RI, Berghahn, pp. 109-132.

-, 1999. Modern models of the past. The life of the Eipo, highlands of West New Guinea, in H. Ullrich (ed.), Hominid Evolution. Lifestyles and Survival Strategies, Gelsenkirchen, Edition Archaea, pp. 268-276.

_, 2000. Menschen und Natur: Interaktionen und Interdependenzen in einer traditionalen Kultur im Hochland West-Neuguineas, in M. Schultz et al. (eds), Schnittstelle Mensch-Umwelt in Vergangenheit, Gegenwart und Zukunft, Göttingen, Cuvillier, pp. 87-91.

—, 2001a. Kampf, Krieg und Versöhnung bei den Eipo im Bergland von West-Neuguinea - Zur Evolutionsbiologie und Kulturanthropologie aggressiven Verhaltens [Fighting, war and reconciliation among the Eipo in the highlands of New Guinea (a contribution to) the evolutionary biology and the cultural anthropology of aggressive behaviour], in W. Fikentscher (ed.), Begegnung und Konflikt Eine Kulturanthropologische Bestandsaufnahme, München, Verlag der Bayerischen Akademie der Wissenschaften, pp. 169-186.

_, 2001b. Sexualverhalten in Melanesien. Ethologische und Humanethologische Aspekte [Sexuality in Melanesia. Ethological and human ethological aspects], in C. Sütterlin and F.K. Salter (eds) Irenäus Eibl-Eibesfeldt. Zu Person und Werk, Frankfurt am Main, Peter Lang, pp. 274-288.

_, 2001c. Bild und Bildnis - Beispiele aus Melanesien und evolutionsbiologische Überlegungen [Image and picture - examples from Melanesia and considerations regarding evolutionary biology], in F. Gräfin von Spreti et al. (eds) Selbstbilder in Psychose und Kunst. Portraitgestaltung als Spiegel Psychischer Befindlichkeit, München, Akademischer Verlag, pp. 11-33.

-, 2003. Ninye kanye: the human mind. Traditional Papuan societies as models to understand evolution towards the social brain, in M. Brüne, H. Ribbert and W. Schiefenhövel (eds), The Social Brain: Evolution and Pathology, John Wiley and Sons, pp. 93-109.

—, 2004. Homo discens, homo docens - Kulturenvergleichende und evolutionsbiologische Perspektiven der Pädagogik [Man learning, man teaching - pedagogics in the perspective of culture comparison and evolutionary biology], in W. Egli and U. Krebs (eds), Beiträge zur Ethnologie der Kindheit. Erziehungswissenschaftliche und Kulturvergleichende Aspekte [Contribution to the Ethnology of Childhood. Pedagogical and ComparativeAspects], Studien zur Ethnopsychologie und Ethnopsychoanalyse, band 5, Münster, Lit Verlag, pp. 165-175.

-, 2004. Kognitions- und Entscheidungsmuster in Melanesien [The framework for cognition and decisonmaking in Melanesia] in $\mathrm{H}$. Schmidinger and C. Sedmak (eds), Der Mensch - Ein "Animal Rationale"? Vernunft - Kognition - Intelligenz [Man A "Rational Animal"? Reason - Cognition - Intelligence], Darmstadt, Wissenschaftliche Buchgesellschaft, pp. 275-292.

SCHIEFENHÖVEL, Wulf, Johanna UHER and Renate Krell (eds), 1993. Im Spiegel der Anderen. Aus dem Lebenswerk des Verhaltensforschers Irenäus EiblEibesfeldt [In the Mirror of the Others. About Irenäus Eibl-Eibesfeldt's lifelong ethological research], München, Realis.

Schultz, Wolfhart and KonRAD, Gunter, 1978. Forschungsprojekt Zoologie 1, in Staatliche Museen 1978 , sheet 7 .

SimON, Artur, 1977. Feldforschungen im östlichen Hochland von West-Irian (Neuguinea) [Field research in the eastern highlands of West Irian], Mitteilungen der Deutschen Gesellschaft für Musik des Orients, no. 14, Hamburg.

-, 1978a. Forschungsprojekt Musikethnologie, in Staatliche Museen 1978, sheets 25a and 25b.

_ $1978 \mathrm{~b}$. Types and functions of music in the eastern highlands of West-Irian (New Guinea), Ethnomusicology 22, pp. 441-455.

_, 1984. Kategorien des Musiklebens in Traditionellen Kulturen Afrikas, Asiens und Ozeaniens, in E. Jost (ed.), Musik Zwischen $E$ und $U$, Veröffentlichungen des Instituts für Neue Musik und Musikerziehung, Darmstadt, no. 25, Mainz, etc., Schott, pp. 32-53.

_, 1987. Possibilities and limitations of historical studies in musical cultures with oral/aural tradition, in Tokumaru and Yamaguti (eds), The Oral and Literate in Music, Tokio.

Simon, Artur (ed.), 1993. Eipo: Musik aus dem Bergland West-Neuguineas [Eipo: music from the West New Guinea highlands], Museum Collection Berlin, CD 20. 2 vols. with commentary. Berlin, Museum für Völkerkunde Berlin, Abteilung Musikethnologie.

Simon, Franz, 1978. Forschungsprojekte Ethnologie - Filmdokumentation, in Staatliche Museen 1978, sheet 24.

—, 1983a. Die Kleidung der Eipo [The clothing of the Eipo], in O. König (ed.), Verhaltensforschung in Österreich. Konrad Lorenz 80 Jahre, Wien, Überreuter, pp 471-81. 
—, 1983b. Eipo (West-Neuguinea, Zentrales Bergland) - Herstellen von Nasenstäbchen aus Kalzit (Arbeitssituation in der Gruppe) [Making Calcite Nose Sticks (A group of Eipo at Work)], E2777.

_, 1983c. Eipo (West-Neuguinea, Zentrales Hochland) - Ein Vormittag in Imarin $[A$ morning in Imarin], E2635.

-, 1985. Eipo (West-Neuguinea, Zentrales Bergland) - Schleifen von Steinklingen am Kirimye. [Grinding Axe Blades by the Kirimye], E2550.

—, 1989a. Eipo (West-Neuguinea, Zentrales Hochland) — Kastrieren eines Schweines [Castrating a Pig], E2456.

—, 1989b. Eipo (West-Neuguinea, Zentrales Hochland) - Aktivitäten vor dem Männerhaus \{Busy in Front of the Men's House], E2537.

_, 1989c. Eipo (West-Neuguinea, Zentrales Hochland)-Sammeln von Wasserinsekten [Collecting Water Insects], E2538.

-, 1989d. Eipo (West-Neuguinea, Zentrales Hochland) — Herstellen eines Strickes [Twisting a Rope], E2539.

—, 1989e. Eipo (West-Neuguinea, Zentrales Hochland) - Kinderspiele 'Taruk Lingingana' und 'Mana' [Children's Games 'Taruk Lingingana'and 'Mana'], E2551.

-, 1989f. Eipo (West-Neuguinea, Zentrales Hochland) - Herstellen einer Peniskalebasse (Sanyum) [Making a Penis Gourd], E2654.

—, 1989g. Eipo (West-Neuguinea, Zentrales Hochland) - Herstellen einer Maultrommel [Making a Mouth Harp], E2558.

—, 1989h. Eipo (West-Neuguinea, Zentrales Hochland) - Spielen einer Maultrommel [Playing a Mouth Harp], E2559.

_, 1989i. Eipo (West-Neuguinea, Zentrales Hochland) - Eipo (West-Neuguinea, Zentrales Hochland) - Haarschnitt [Haircuts], E2565.

—, 1989j. Eipo (West-Neuguinea, Zentrales Hochland) - Schäften eines Steinbeils in Imarin [Hafting a Stone Adze in Imarin], E2906.

-, 1989k. Eipo (West-Neuguinea, Zentrales Hochland) - Schleifen von Steinklingen am Mumye [Grinding Axe Blades by the Mumye], E2907.

Simon, Franz and Klaus Helfrich, 1987. Eipo (WestNeuguinea, Zentrales Hochland) - Herstellen eines Perlenbandes in Halbwebtechnik [Making a Band set with Glass Beads by Means of a Weaving Bow], E2595. Accompanying paper Ohnemus 1989.

Simon, Franz and Wulf SchiEFENHÖVEL, 1983a. Eipo (West-Neuguinea, Zentrales Hochland) - Anfertigen eines Rückenschmucks [Making a Back Ornament], E2437. Accompanying paper Schiefenhövel $1996 b$

—, 1983b. Eipo (West-Neuguinea, Zentrales Hochland) - Vorgänge Anläßlich der Zeremoniellen Übergabe einer Stirnbinde aus Nassa-Schecken
[Ceremonial Handover of a Nassa Shell Head Band], E2457.

-, 1989a. Eipo (West-Neuguinea, Zentrales Hochland) - Wundbehandlung mit Schweinfett und durch Wärmeanwendung [Treating a Wound with Pig Fat and by Applying Heat], E2509. Accompanying paper Schiefenhövel 1996 f.

_, 1989b. Eipo (West-Neuguinea, Zentrales Hochland) - Behandlung einer Infizierten Wunde [Treating an Infected Wound], E2510. Accompanying paper Schiefenhövel 1996e.

—, 1989c. Eipo (West-Neuguinea, Zentrales Hochland) - Durchbohren der Nasenscheidewand [Piercing the Nasal Septum], E2511. Accompanying paper Schiefenhövel 1996c.

_, 1989d. Eipo (West-Neuguinea, Zentrales Hochland) - Durchbohren des Ohrläppchens [Piercing the Earlobe], E2512. Accompanying paper Schiefenhövel 1996d.

—, 1989e. Eipo (West-Neuguinea, Zentrales Hochland) - Ab- und Anlegen von Hüftgürtel und Peniskalebasse [Taking off and Putting on Waist Band and Penis Gourd], E2513.

—, 1989f. Eipo (West-Neuguinea, Zentrales Hochland) — Körperbemalung der Mädchen [Painting Girls’ Bodies], E2557.

—, 1989g. Eipo (West-Neuguinea, Zentrales Hochland) - Nächtlicher Tanz und Gesang bei einem 'Mote' Fest [Dancing and Singing During the Night on the Occasion of a 'Mote' Feast], E2799.

_, 1989h. Eipo (West-Neuguinea, Zentrales Hochland) - 'Mote', ein Besuchsfest in Munggona ['Mote', a Festive Visit in Mungguna], E2803.

-, 1989i. Eipo (West-Neuguinea, Zentrales Hochland) - Zerlegen und Zubereiten von Schweinen durch Frauen in Munggona [Women Slaughtering and Cooking Pigs in Munggona], E2902.

Staatliche Museen Preuszischer Kulturbesitz BERLIN, 1978. Forschungen im Bergland von Neuguinea. Das Interdisziplinäre West-Irian Projekt [Research in the Highlands of New Guinea. The Inter-disciplinary West Irian Project].

WALTER, Sven, 1978. Forschungsprojekt Linguistik, in Staatliche Museen 1978, sheet 15.

-, 1982. Eipo (West-Neuguinea, Zentrales Hochland) - Gartenarbeiten (Hochbeetbau) [Garden Work (High Mound Cultivation)], E2660.

Papers Presented at the 1990 Conference "The Mek And Their Neighbours ", Seewiesen, Bavaria

I do not include year of presentation in this section of the bibliography. However, when contributors to the conference produced in that same year a publication that I list in another section of the bibliography, I refer in the text of the essay to the conference paper as '1990'.

Bromley, H. Myron, The Highlanders of Irian Jaya; whence? 
Brumbaugh, Robert, A changing self-portrait of the Mountain Ok: Feranmin history and myth.

Craig, Barry, Continuities and discontinuities in the material culture of the mountain-Ok and their neighbours.

EIBL-EIBESFELDT, Irenäus, Politics in kin-based societies and their phylogenetic origin.

GARDNER, Don, Mianmin leadership.

Giay, Benny. Man and environment. Deforestation as a causal factor in the rise of cargo movements in the Paniai region, Western Central Highlands of Irian Jaya.

GoDSCHALK, Jan, Deregulation of population control in the Sela valley.

Gunawan, Suriadi, Health and nutritional conditions in the Central Highlands of Irian Jaya.

Jorgensen, Dan, 'Production and the aims of exchange: Telefol crop regimes in historical perspective'.

HAYs, Terence, The centrality of the Mek-Ok region in the diffusion of tobacco in New Guinea.

HeEsCHEN, Volker, Dangers from the periphery - men and women in mythical times.

_, 1990a, The position of the Mek languages within the Papuan languages - history, typology and speech.

HeIDER, Karl, Grand Valley Dani sexuality and its cultural basis.

Hylkema, Sibbele, Transaction of the ownership of land with the Ekagi around the Wissel-lakes.

Hyndman, David, Living with ancestral rainforests. Wopkaimin cultural management of resources.

HiEPKo, Paul, Eipo plant nomenclature and classification compared with other folk taxonomic systems.

$\mathrm{KoCH}$, Gerd, Man and project.

LOUWERSE, Jan, Una traditional causality and adaptation to environment: repercussion of cognition of environment on sociocultural interaction.

MackenzIE, Maureen, The Telefol feather decorated string bag. The potency of a cultural artefact with androgynous forms.

MenzIES, J.I., The natural environment of the Wopkaimin.

Michel, Thomas, Mek und Ok. Unterschiede und Gemeinsamkeiten.

Morren, George, Remote sensing and controlled comparison: an application to the Mountain Ok region, Papua New Guinea.

PÉtrequin, Pierre and Anne-Marie, Yeleme axes, Mumyeme adzes. The distribution of polished stone blades in central Irian Jaya.

Polier, Nicole, Migrant Min, miners and gardeners: social movement and social transformation among the Paiwolmin of Golgobip.

Poole, John. F. Porter, Between 'classic' highlands and 'fringe' highlands: a confluence of ecological, sociocultural, and ritual forms and forces in the historical constitution of the Bimin-Kuskusmin of the Mountain-Ok region of New Guinea.

Roberts, Christopher, Music genre [sic] of the Wopkaimin.

RoYL, Ekkehart, The different types of multi-part singing and their distribution in the highlands of Irian Jaya.

Scheepstra, G.L. and M.G. Scheepstra-Oomkens, Native doctors and western medicine: about Jeli mythology and misunderstandings on both sides.

SCHIEFEnHövel, Wulf, Aggression and character enhancement as possible causes of highlands New Guinea cultural diversity.

Schwartz, Jessica, Robert Brumbaugh, and James AlLEN, Endocrine aspects of short stature - Telefomin and Atbalmin.

Strathern, Andrew, "We carry the man": on the ritualization of violence in the highlands of New Guinea.

STÜRZENHOFECKER, Gabriele, Migrating gardens: ecology and identity in the Baliem valley.

WALTER, Sven, Submorphematic semanticity in Eipo: Phonological coding of semantic features.

\section{Other Sources Quoted}

APPELL, George, 1968. The Dusun languages of Northern Borneo; Rungus Dusun and related problems, Oceanic Linguistics 7, pp. 1-15.

BAKELS, Jet and Nico DE Jonge, 2001. Indië Ontdekt. Expedities en Onderzoek in de Oost en de West, Leiden, KITLV Uitgeverij.

Ballard, Chris, 1998. The sun by light: Huli moral topography and myths of a time of darkness, in: L. R. Goldman and C. Ballard (eds), Fluid Ontologies. Myth, Ritual and Philosophy in the Highlands of Papua New Guinea, Westport, CT, Bergin and Harvey, pp. 67-85.

_, 2000. Collecting Pygmies: The 'Tapiro' and the Britisch Ornithologists' Union expedition to Dutch New Guinea, 1910-1911, in M. O'Hanlon and R. Welsch (eds), Hunting the Gatherers: Ethnographic Collectors, Agents and Agency in Melanesia, New York / Oxford, Berghahn Books, pp. 127-153.

BARnes, John, 1962. African models in the New Guinea Highlands, Man 62, pp. 5-9. Reprinted in: BARNES, John, 1990. Models and Interpretations, Cambridge, Cambridge University Press, pp. 4455 .

BARTH, Fredrik, 1975. Ritual and Knowledge among the Baktaman of New Guinea, Oslo, Universitetsforlaget / New Haven, Yale University Press.

Brandt, Erik, 2001. On War and Anthropology. A History of Debates concerning the New Guinea Highlands and the Balkan. Place of publication not mentioned, Rozenberg Publishers. 
Brumbaugh, Robert, 1990a. "Afek sang": the old woman's legacy to the Mountain-Ok, in: B. Craig and D. Hyndman (eds), 1990, pp. 54-8733.

Craig, Barry, 1988. Art and Decoration of Central New Guinea, Aylesbury, UK, Shire Publications.

_, 1990a. Relic and trophy arrays as art among the Mountain Ok, Central New Guinea in A. and L. Hanson (eds), Art and Identity in Oceania, Bathurst, NSW, Crawford House Press, pp. 196-210.

Craig, Barry and David. Hyndman (eds), 1990. Children of Afek. Tradition and Change among the Mountain-Ok of Central New Guinea, Oceania Monograph 40, Sydney, University of Sydney.

Dorney, Sean, 2000. Papua New Guinea. People, Politics and History since 1975, Revised Edition, Sydney, ABC Books.

DE VRIES, Lourens, 2000. Review of Heeschen 1998a (MKU 23), Bijdragen tot de Taal-, Land-en Volkenkunde 156, pp. 151-154.

DE Kock, A.C., 1912. Enige ethnologische en anthropologische gegevens omtrent een dwergstam in het bergland van Nieuw-Guinea, Tijdschrift van het Koninklijk Nederlandsch Aardrijkskundig Genootschap 29, pp. 154-170. A translation is published by Jan Godschalk (1999).

DWYER, Peter, 1996. Boars, barrows and breeders: the reproductive status of domestic pig populations in mainland New Guinea, Journal of Anthropological Research 52, pp. 481-500.

Dwyer, Peter and Monica Minnegal, in press. Person, place or pig: animal attachments and human transactions in New Guinea, in: J. Knight (ed.), Animals in Person: Cultural Perspectives on HumanAnimal Relations, Oxford, Berg.

EIBL-EIBESFELDT, Irenäus, 1989. Human Ethology. Extended and revised English edition of Die Biologie des menschlichen Verhaltens, first edition 1984, translated from the German by P. Wiessner-Larson and A. Heunemann, Hawthorne, NY, Aldine de Gruyter.

Gluckman, Max, 1956. Custom and Conflict in Africa, Oxford, Basil Blackwell.

Godelier, Maurice, 1982. La Production des Grands Hommes, Paris, Flammarion.

—, 1990. Avant-propos, in: Lemonnier, 1990, pp. 9 19.

-, 1991. An unfinished attempt at reconstructing the social processes which may have prompted the transformation of great-men societies into big-men societies, in M. Godelier and M. Strathern (eds), 1991, pp. 275-304.

Godelier, Maurice and Marilyn STrathern (eds), 1991. Big Men and Great Men. Personifications of Power in Melanesia, Cambridge, Cambridge University Press.
Godschalk, Jan, 1993. Sela Valley. An Ethnography of a Mek Society in the Eastern Highlands. Irian Jaya, Indonesia, Geldermalsen, the Netherlands, Logoconsult.

_, 1999. A.C. de Kock's encounter with the "Goliath Pygmies". The first ethnographic data from the Mek culture area in the Eastern Highlands of Irian Jaya, The Journal of Pacific History 34, pp. 219-228.

Golson, Jack and Axel SteEnsBerg, 1985. The tools of agricultural intensification in the New Guinea Highlands, in: I.S. Farrington (ed.), Prehistoric Intensive Agriculture in the Tropics, Oxford, Bar International Series 232, pp. 347-382.

Harrison, Simon, 1990. Stealing People's Names. History and Politics in a Sepik River Cosmology, Cambridge, Cambridge University Press.

Hayward, Douglas, 1997. Vernacular Christianity among the Mulia Dani. An Ethnography of Religious Belief among the Western Dani of Irian Jaya, Indonesia, Lanham, Maryland, American Society of Missiology / University Press of America.

Heyne, K., 1950. De Nuttige Planten van Indonesië [The Useful Plants of Indonesia], 2 vols, 's-Gravenhage / Bandung, van Hoeve.

Hylkema, Sibbele, 1974. Mannen in het Draagnet [Men in the Carrier Bag], Verhandelingen van het Koninklijk Instituut voor Taal-, Land- en Volkenkunde 67, 's-Gravenhage, Martinus Nijhoff.

Hyndman, David, 1991. The Kam basin homeland of the Wopkaimin: a sense of place, in: A. Pawley (ed.), Man and a Half. Essays in Pacific Anthropology and Ethnobiology in Honour of Ralph Bulmer, Auckland, The Polynesian Society, pp. 256-265.

Hyndman, David and George Morren Jr, 1990. The human ecology of the Mountain-Ok of Central New Guinea: a regional and inter-regional approach, in B. Craig and D. Hyndman (eds), 1990, pp. $9-26$

Kooljman, Simon, 1962. Material aspects of the Star Mountains culture, Nova Guinea, n.s. 10 (2), pp. 1544.

Laporan expedisi ilmiah lembah-X 2 Oktober sampai dengan 20 Desember 1969 di Irian Barat [Report of the scholarly expedition to the X-valley from 2 October through to 20 December 1969 in West Irian], Komando Daerah Militer 17 "Cenderawasih", Jayapura; mimeographed report.

LAVELY, William and R. BIN Wong, 1998. Revising the Malthusian narrative: the comparative study of population dynamics in imperial China, Journal of Asian Studies 57, pp. 714-748.

LAwrEnce, Peter, 1984. The Garia. An Ethnography of a Traditional Cosmic System in Papua New Guinea, Carlton, Vic, Melbourne University Press.

Lemonnier, Pierre, 1990. Guerres et Festins. Paix,Échanges et Compétition dans les Highlands de

33. This is the title as mentioned at the beginning of the paper. In the table of contents the title mentioned is: « Afek sang »: the « old woman » myth of the Mountain-Ok. 
Nouvelle-Guinée [Wars and Feasts. Peace, Exchanges and Competition in the Highlands of New Guinea], Paris, Éditions de la Maison des Sciences de l'Homme.

_, 1991. From great men to big men: peace, substitution and competition in the Highlands of New Guinea, in M. Godelier and M. Strathern (eds), 1991, pp. 7-27.

Michel, Thomas, 1986. Raumkonzept und Siedlungsstrategie in den Star Mountains von Neuguinea [Conceptualization of space and settlement strategy in the Star Mountains of New Guinea], Paideuma 32, pp. 319-343.

_, 1988. Kulthäuser as ökologische Modelle [Cult houses as ecological models], Paideuma 34, pp. 225241.

—, 1994. Geschichtsüberlieferung bei den Nalumin (Star Mountains, Papua-Neuguinea) [Oral history among the Nalumin], in B. Hauser-Schäublin (ed.), Geschichte und mündliche Überlieferung in Ozeanien, Basler Beiträge zur Ethnologie 37, Basel, Ethnologisches Seminar der Universität und Museum für Völkerkunde, pp. 129-159.

Mitton, Robert, 1983. The Lost World of Irian Jaya, Melbourne, Oxford University Press.

PÉtrequin, Pierre and Anne-Marie, with J. Coras, H. Dartevelle, A. Maître and M. Rossy, 1993. Écologie d'un Outil: la Hache de Pierre en Irian Jaya (Indonésie) [Ecology of a Tool: the Stone Axe in Irian Jaya], Monographie du Centre de Recherches Archeologiques 12, Paris, CNRS Éditions.

Ploeg, Anton, 1969. Government in Wanggulam, Verhandelingen van het Koninklijk Instituut voor Taal-, Land- en Volkenkunde 57, The Hague, Martinus Nijhoff.

Pouwer, Jan, 1964. A social system in the Star Mountains: toward a reorientation of the study of social systems, in J.B. Watson (ed.), New Guinea. The Central Highlands,. Special Publication of: American Anthropologist 66 (4, part 2), pp. 133-161.

-, 1974. Toward a configurational approach to society and culture in New Guinea, Journal of the Polynesian Society 75, pp. 267-286.

Powell, Jocelyn, 1976. Ethnobotany, in K. Paijmans (ed.), New Guinea Vegetation, Canberra, Australian National University Press, pp. 106-183.

Rumsey, Alan and James WeInER (eds), 2001. Emplaced Myth. Space, Narrative and Knowledge in Aboriginal Australia and Papua New Guinea, Honolulu, University of Hawai'i Press.

SAulnier, Tony, with M. Bisiaux, 1963. Headhunters of Papua, New York, Crown Publishers.

Schumaker, Lyn, 2001. Africanising Anthropology. Fieldwork, Networks, and the Making of Cultural Knowledge in Central Africa, Durham and London, Duke University Press.

SeIler-Baldinger, A. and Sylvia OHNemus, 1986 'Zum Problem des Halbwebens', Verhandlungen Naturforschende Gesellschaft Basel 96, pp. 85-97.
Sillitoe, Paul, 1979. Give and Take. Exchange in Wola Society, New York, St Martin's Press.

-, 1988. Made in Niugini. Technology in the Highlands of Papua New Guinea, London, British Museum Publications.

Silzer, Peter and Heljä Heikninen Clouse, 1991. Index of Irian Jaya Languages, Special Publication of: Irian. Bulletin of Irian Jaya.

SIMS, Andrew and Anne, 1992. Rituals and Relationships in the Valley of the Sun. The Ketengban of Irian Jaya, International Museum of Cultures, publication no. 30, Jayapura, Cenderawasih University / Dallas, Texas, International Museum of Cultures.

SIMS, Andrew, 1992. Of red men and rituals: the Ketengban and the supernatural, in A. and A. Sims, 1992, pp. 1-89.

SMITH, Thomas, with R.Y. Eng and R.T. Lundy, 1977. Nakahara. Family Farming and Population in a Japanese Village, 1717-1830, Stanford, Stanford University Press.

SoRENSON, E. Richard, 1976. On the Edge of the Forest. Land, Childhood and Change in a New Guinea Protoagricultural Society, Washington, D.C., Smithsonian Institution Press.

Stewart, Pamela and Andrew Strathern, 2001. Origin versus creative powers. The interplay of movement and fixity, in A. Rumsey and J. Weiner (eds), 2001, pp. 79-98.

Strathern, Andrew, 1969. Finance and production: two strategies in New Guinea highlands exchange systems, Oceania 40, pp. 42-67.

-, 1970. Male initiation in the New Guinea highlands societies, Ethnology 9, pp. 373-379.

STRATHERN, Marilyn, 1991. Introduction, in M. Godelier and M.Strathern (eds) 1991, pp. 1-4.

Sütterlin, Christa and Frank SAlter (eds), 2001. Irenäus Eibl-Eibesfeldt. Zu Person und Werk. Festschrift zum 70. Geburtstag, Bern, etc, Peter Lang.

TwoHig, A. (ed.), 1986. Liklik Buk. A Sourcebook for Development Workers in Papua New Guinea, Lae, Liklik Buk Information Centre.

WeINER, James, 1988. The Heart of the Pearl Shell. The Mythological Dimension of Foi Sociality, Berkeley, Los Angeles and London, University of California Press.

-, 1991. The Empty Place. Poetry, Space and Being among the Foi of Papua New Guinea, Bloomington and Indianapolis, Indiana University Press.

Wiessner, Polly and Akii Tumu, 1998. Historical Vines. Enga Networks of Exchange, Ritual and Warfare in Papua New Guinea, Washington, DC, Smithsonian Institution.

ZöLlnER, Siegfried, 1977. Lebensbaum und Schweinekult. Die Religion der Jalî im Bergland von IrianJaya, Darmstadt, Theologischer Verlag Brockhaus. An abbreviated translation, by Jan Godschalk, is: ZöLLNER, Siegfried, 1988. The Religion of the Yali in the Highlands of Irian Jaya. Point Series, $\mathrm{n}^{\circ} 13$. 
